Leonardo Curval Massaro

\title{
PLANEJAMENTO DA EXECUÇÃO DE REMENDOS EM VIAS URBANAS SOB O ENFOQUE DA LOGÍSTICA DE SERVIÇOS
}

Dissertação apresentada à Escola de Engenharia de São Carlos da Universidade de São Paulo, como parte dos requisitos para a obtenção do Título de Mestre em Engenharia Civil: Transportes.

Orientador: Prof. Dr. Edson Martins de Aguiar

São Carlos

2005 


\section{Dedicatória}

Ao meu pai Leonel e ao meu avô Diamantino 


\section{AGRADECIMENTOS}

A Deus por todas as oportunidades.

Ao Professor Edson Martins de Aguiar pela orientação.

Aos meus pais, avós e irmão pelo apoio e incentivo.

À minha namorada Raquel por todo carinho, paciência e compreensão nesses últimos meses.

Ao Professor José Bernardes Felex pelo incentivo para começar o mestrado

À Coordenadoria de Aperfeiçoamento de Pessoal de Nível Superior CAPES pela bolsa de estudos concedida.

À DATEC e a Prefeitura Municipal de São Carlos pelas explicações e dados gentilmente fornecidos.

Aos meus grandes amigos de República por todos os ótimos anos de convivência, os antigos moradores Farzin, Paulinho, Leandro Lima, Nilson, Leonardo Ribeiro, Leonardo Hotta e Jucá; os atuais moradores: Ferdinando, Filipe, Emerson, Leandro Polli, Ariel e principalmente ao Maurício pela ajuda na elaboração das figuras desta dissertação.

Aos funcionários e amigos do Departamento de Transportes da Escola de Engenharia de São Carlos que ajudaram no decorrer dessa etapa, especialmente ao Lucas, Alessandre e Cinthya que participaram da elaboração da base de dados. 


\section{SUMÁRIO}

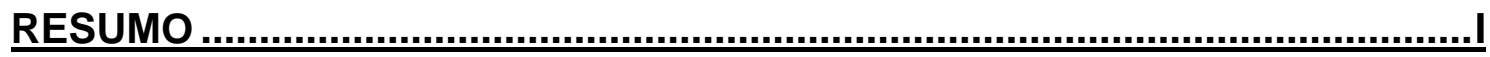

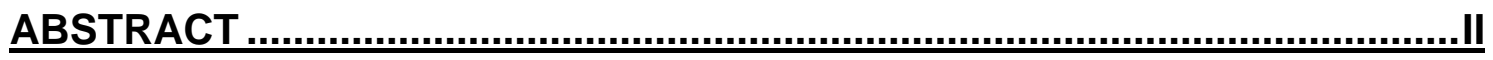

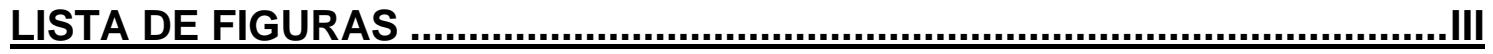

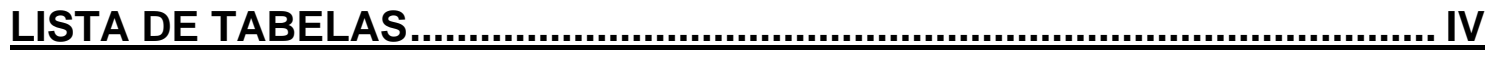

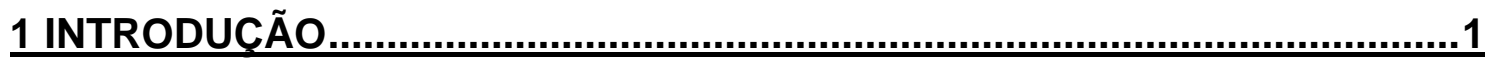

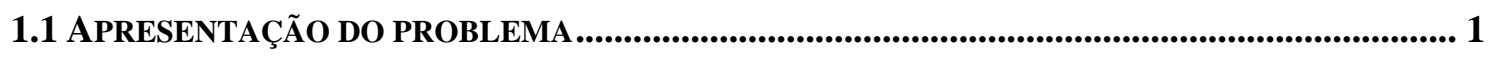

1.2. JUSTIFICATIVA PARA A ABORDAGEM ..................................................................................... 2

1.3 OBJETIVOS GERAIS E ESPECÍFICOS.............................................................................. 4

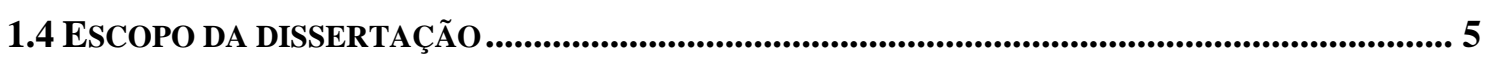

$2 \underline{0}$ SERVIÇO DE REMENDO EM PAVIMENTOS ...................................7

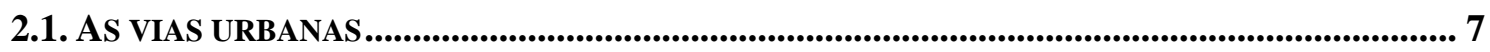

2.2 AS ATIVIDADES DE MANUTENÇÃO E REABILITAÇÃo DE PAVIMENTOS................................. 9

2.3 A EXECUÇÃO DOS REMENDOS ................................................................................................... 12

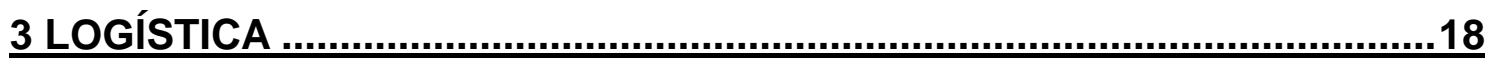

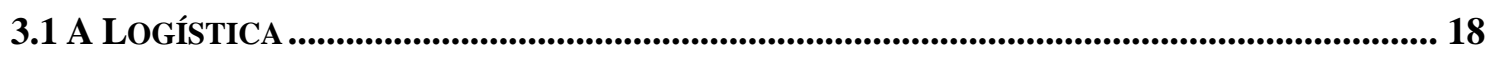

3.2 LOGÍSTICA DE SERVIÇOS ..................................................................................... 19

3.2.1 DifERENÇA DA LoGíSTICA DE MANUFATURAS ........................................................ 20

3.3 EFEITO DO NÍVEL DE SERVIÇO SOBRE AS VENDAS.................................................................. 22

3.4 NÍVEIS DE PLANEJAMENTO: ESTRATÉGICO / TÁTICO/ OPERACIONAL ................................ 25

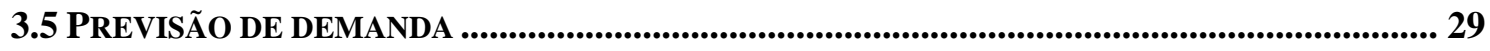

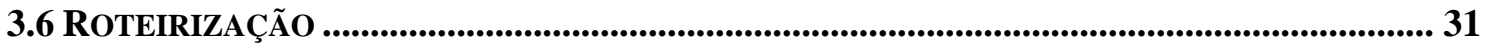

3.6.1 O PROBLEMA DE CoBERTURA DE ARCoS........................................................................ 33

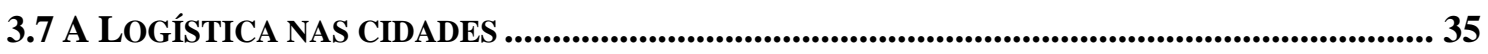

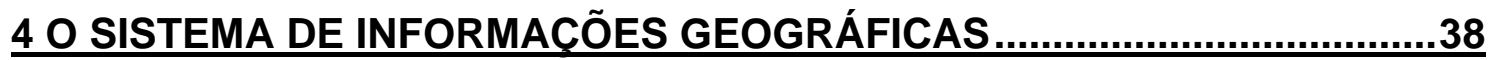

4.1 A IMPORTÂNCIA DO USO DO SIG NO PLANEJAMENTO URBANO ......................................... 38

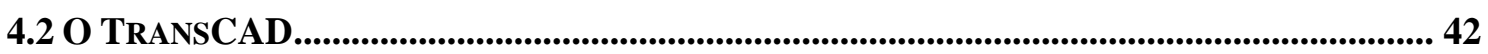




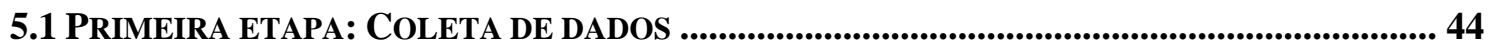

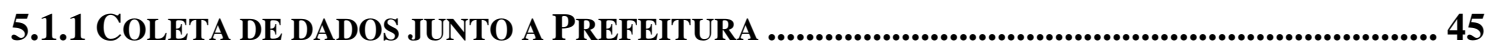

5.1.2 ACOMPANHAMENTO DAS EQUIPES QUE EXECUTAM REMENDOS NOS PAVIMENTOS DE

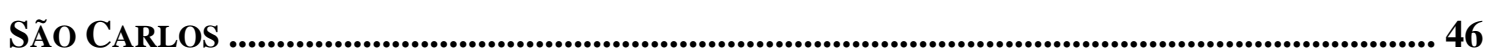

5.2 SEGUNDA ETAPA: APLICAÇÃo dA FERRAMENTA DE ROTEIRIZAÇÃo do TRANSCAD.... 48

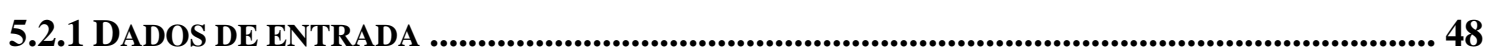

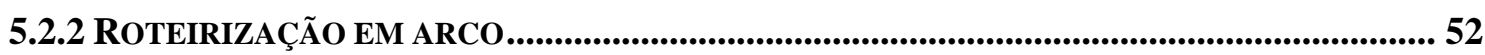

5.3 TERCEIRA ETAPA: PREVISÃo DE REMENDOS DE ACORDO COM A PLUVIOSIDADE ........... 55

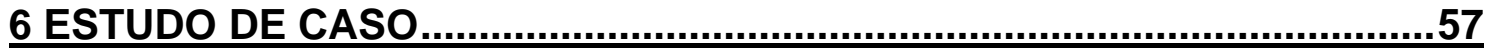

6.1 CARACTERÍSTICA DA CIDAdE DE SÃo CARLOS ................................................................... 57

6.2 A MANUTENÇÃO DAS VIAS DE SÃo CARLOS.............................................................................. 58

6.2.1 O SERVIÇO DE REMENDOS NOS PAVIMENTOS DA CIDADE DE SÃo CARLOS .................... 58

6.2.2 A EXECUÇÃO DO SERVIÇO................................................................................................ 61

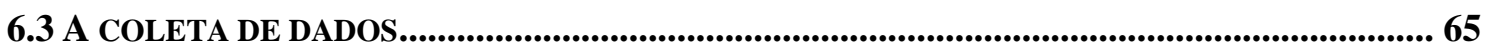

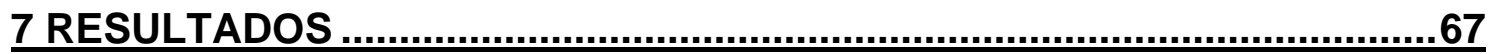

7.1 RESULTADOS OBTIDOS EM CAMPO ......................................................................................... 67

7.2 RESULTADOS OBTIDOS COM O TRANSCAD ...................................................................... 72

7.3 PREVISÃo DE DEMANDA POR SERVIÇOS DE REMENDOS....................................................... 82

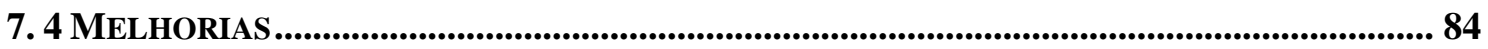

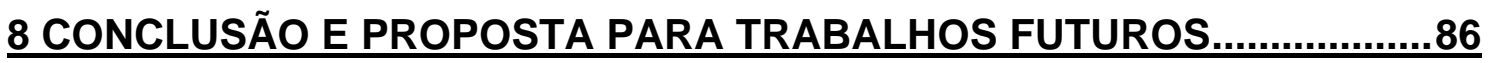

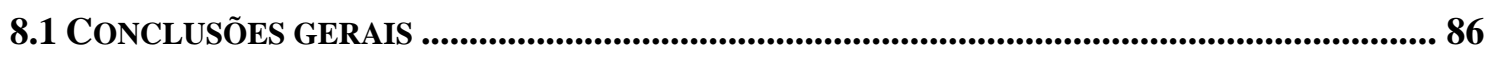

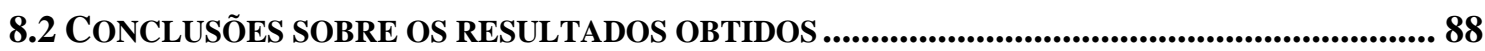

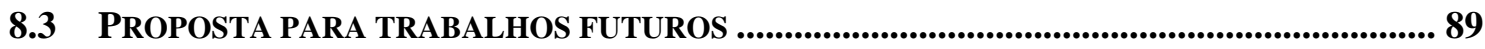

8.3.1 MODELO DE PREVISÃO DE DEMANDA.................................................................................... 89

8.3.2 DIMENSIONAMENTO DE FROTAS.............................................................................................. 89

8.3.3 PESQUISA OPERACIONAL........................................................................................................... 90

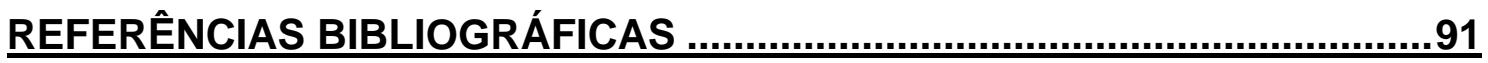

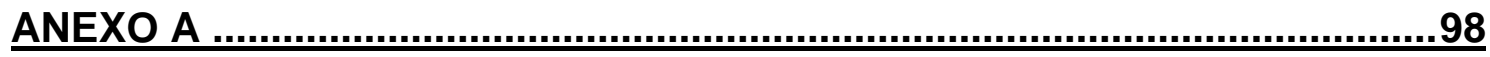




\section{RESUMO}

O objetivo deste trabalho é apresentar os conceitos da Logística, em especial a Logística de Serviços, e algumas de suas ferramentas, como a roteirização de veículos e previsão de demanda por serviços, aplicadas aos serviços urbanos, neste caso o serviço de remendos em pavimentos, visando aumentar a eficiência desse serviço. O serviço de remendos, muitas vezes chamado de "tapa-buracos", é uma atividade de manutenção comum nas cidades. Para observar a aplicação das ferramentas foi elaborado um estudo de caso na cidade de São Carlos. Dados sobre o serviço de remendos em pavimentos foram coletados e, com a ajuda de um Sistema de Informações Geográficas - SIG, foram gerados roteiros que foram comparados com os dados originais. As rotas simuladas pelo SIG foram mais eficientes do que as praticadas na realidade, mostrando a utilidade dos conceitos da Logística e também a utilidade do SIG na gerência da infra-estrutura urbana. A previsão de demanda por serviços de remendos não pôde ser observada devido à falta de dados históricos, fundamentais a essa etapa do trabalho.

Palavras chave: remendos em pavimentos urbanos, logística de serviços, roteirização, sistema de informação geográfica. 


\section{ABSTRACT}

The objective of this work is to introduce the concepts of Logistics, especially the Service Logistics and some of its tools as the vehicle routing and the demand forecast for services, applied to the urban services, in this case the patching service in pavements in order to increase the efficiency of this service. The patching service, many times called "tapa-buracos" (in Brazil), is a common activity of maintenance in the cities. To observe the application of the tools one case study was elaborated in the city of São Carlos. Data about the patching service in pavements were collected and, helped by the Geographic Information System - GIS, routes were created and compared to the original data. The paths simulated by the GIS were more efficient than the real ones, showing the utility of the Logistics concepts and also the utility of the GIS on the management of the urban infrastructure. The demand forecast for services of patching could not be observed due of the lack of historical data, essential to this part of the work.

Key words: patching in urban pavements, service logistics, vehicle routing, geographical information system. 


\section{LISTA DE FIGURAS}

Figura 1.1 - Panela na cidade de São Carlos .1

Figura 1.2 -Defeito em reparo de vala na cidade de São Carlos .......................1

Figura 1.3 - Reportagem Estado de São Paulo - 0510312004 ..............................

Figura 1.4 - Reportagem Estado de São Paulo - 2810212004 …........................

Figura 2.1 - Conceito de serventia - desempenho..........................................10

Figura 2.2 - Procedimentos para execução de um remendo permanente .......15

Figura 3.1 - Relação entre vendas e serviço ao cliente ...................................23

Figura 3.2 - Compensações gerais no custo-receita em vários níveis de serviço

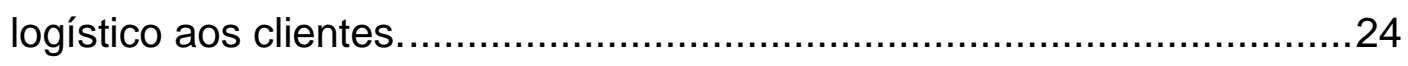

Figura 3.3 - Rentabilidade de uma carteira de clientes ................................25

Figura 3.4 - Implicações da variação da demanda com relação à capacidade 29

Figura 3.5 - Minimização de picos de demanda............................................30

Figura 3.6 - Diferentes políticas de capacidade ...........................................30

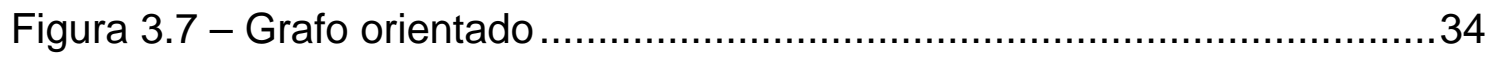

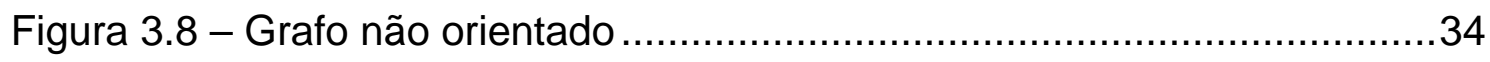

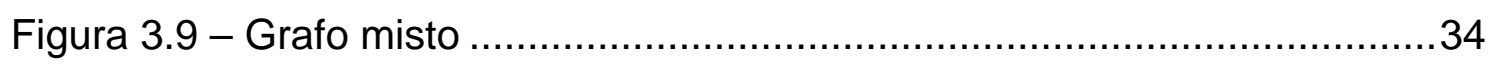

Figura 4.1 - Conceito de sistema de gerência global da infra-estrutura urbana (adaptada de ZANG et al., 1994) ..................................................... 40

Figura 4.2 - Representação geográfica em camadas de um SIG ...................41

Figura 5.1 - Esquema das etapas do Método .................................................4

Figura 5.2 - Planilha entregue aos motoristas ............................................. 4

Figura 5.3 - Passagem de dados do croqui para os links no TransCAD ..........49

Figura 5.4 - Distribuição espacial das panelas em São Carlos durante o

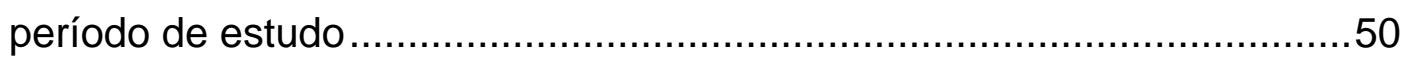

Figura 5.5 - Separação dos links das ruas nos locais das panelas..................50

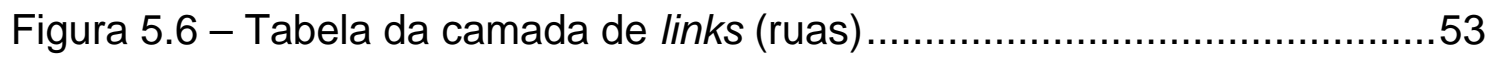

Figura 5.7 - Territórios dos links que contém serviços .....................................53

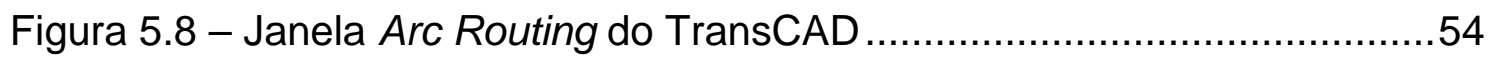

Figura 6.1 - Localização geográfica do município de São Carlos .....................57

Figura 6.2 - Ciclo do pedido do serviço de remendos na cidade de São Carlos 
Figura 6.3 - Usina para preparação de PMF da Prefeitura Municipal de São Carlos

Figura 6.4 - Caminhão do SAAE de São Carlos para a execução de remendos

Figura 6.5 - Caminhão carroceria adaptado para levar os materiais necessários

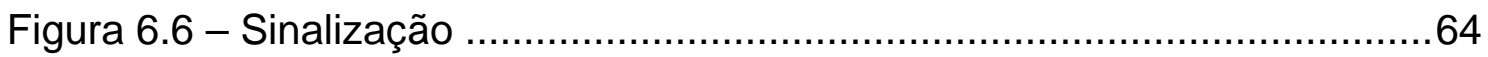

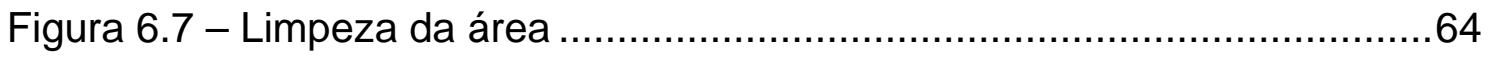

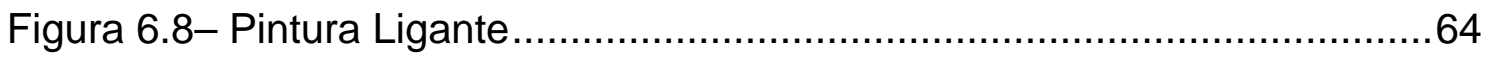

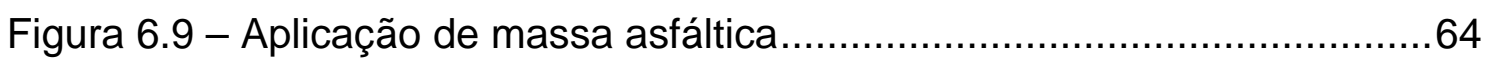

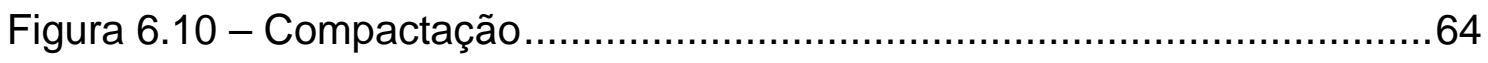

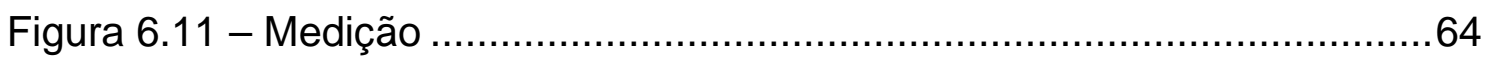

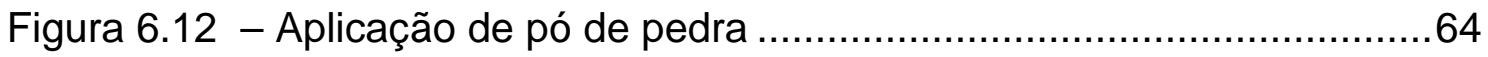

Figura 6.13 - Serviço executado de forma incorreta: uso de material solto para

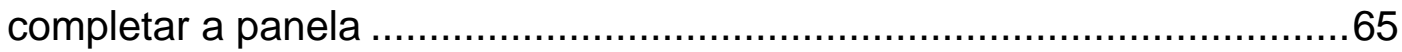

Figura 7.1 - Remendos executados na Travessa 1 no dia 29/09/2004 ............68

Figura 7.2 - Roteiro inadequado, efetuado no dia 28/09/2004 .......................69

Figura 7.3 - Roteiro com baixo rendimento, efetuado no dia 30/09/2004 .........69

Figura 7.4 - Todos os roteiros gerados pelo TransCAD .................................75

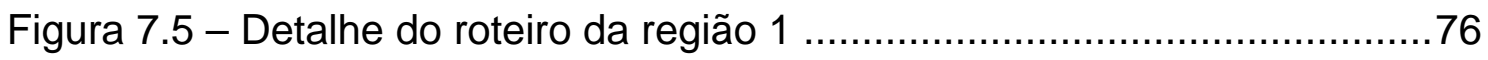

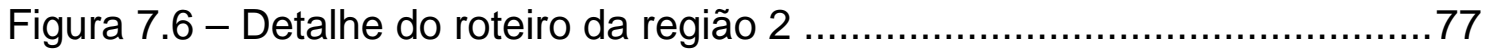

Figura 7.7 - Detalhe do roteiro da região 3 ................................................. 78

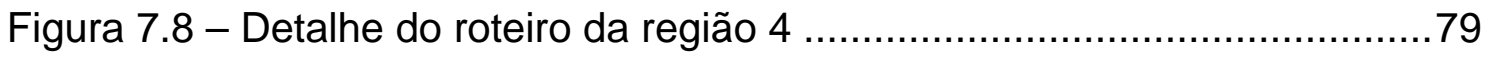

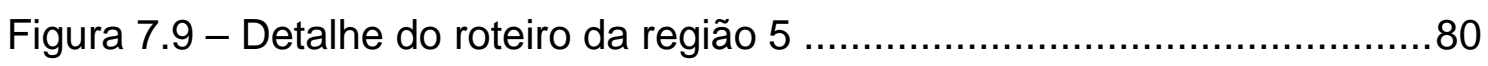

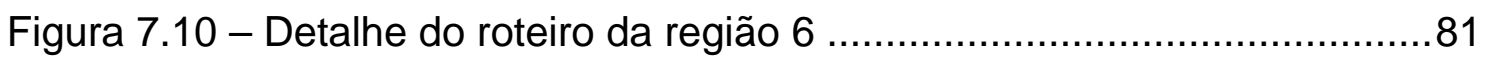

Figura 7.11 - Quantidades de remendos executados, e pluviosidade de Janeiro

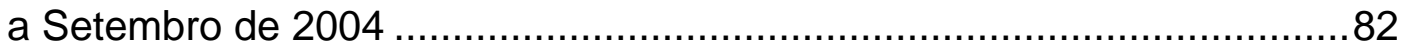

Figura 7.12 - Distribuição dos remendos executados versus a pluviosidade de

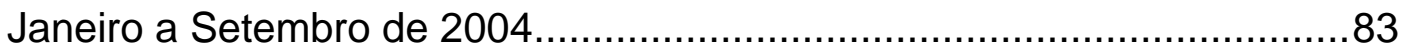

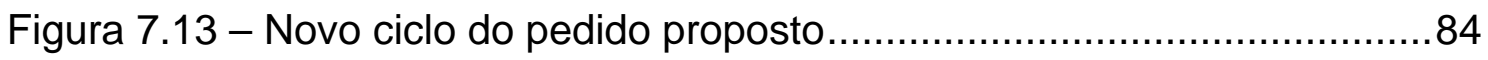




\section{LISTA DE TABELAS}

Tabela 2.1 - Participação percentual das redes no custo total da infra-estrutura urbana 8

Tabela 3.1 - Exemplo de tomada de decisões estratégicas, táticas e operacionais 26

Tabela 6.1 - Quantidade de remendos executados e pluviosidade. 58

Tabela 7.1 - Quantidades de remendos executados e quilometragem percorrida por equipe observada durante o período de estudo 70

Tabela 7.2 -Tempos gastos por equipe durante o período de estudo. .71

Tabela 7.3 - Quantidades e tempos totais do serviço de remendos em pavimentos observados durante o período de estudo .72

Tabela 7.4 - Resultados do TransCAD para a roteirização em arco...... .73

Tabela 7.5 - Resultados do TransCAD agrupados em três dias de trabalho ...74 


\section{INTRODUÇÃO}

\subsection{Apresentação do problema}

As vias urbanas, devido às intempéries, ao uso pelo tráfego de veículos, a problemas estruturais e à idade do pavimento acabam se desgastando ou apresentando diversos defeitos.

Entre os defeitos do pavimento, esta pesquisa focará o problema dos buracos nas vias urbanas, definidos como panelas (Figuras 1.1 e 1.2), pois tal defeito afeta diretamente o tráfego nas cidades, seja diminuindo a velocidade de tráfego nas ruas e avenidas, seja ocasionando acidentes. Isso aumenta o custo do transporte, assim como afeta a segurança e o conforto de seus usuários.

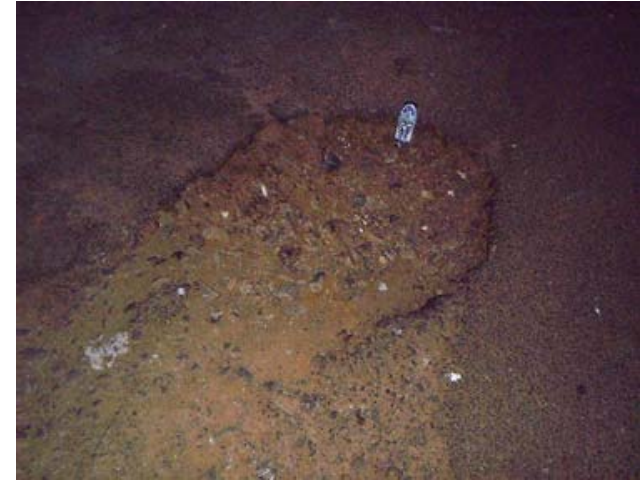

Figura 1.1 - Panela na cidade de São Carlos

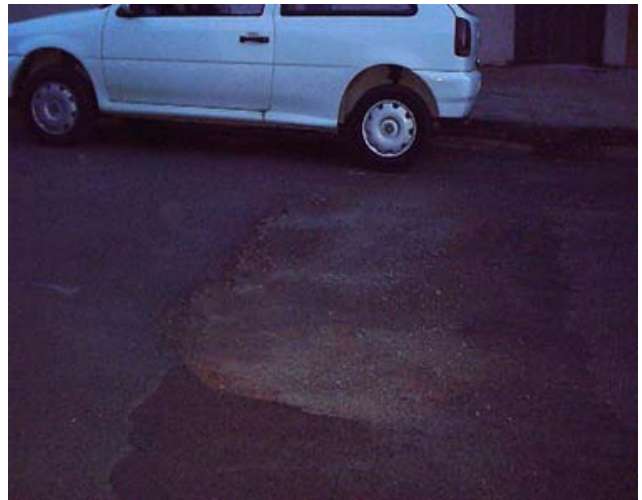

Figura 1.2 -Defeito em reparo de vala na cidade de São Carlos

$\mathrm{Na}$ tentativa de corrigir o problema, as prefeituras formam equipes com funcionários e equipamentos próprios ou contratam empresas para efetuar um serviço comumente chamado de "tapa-buracos". 
Ocorre que o serviço de tapa-buracos, muitas vezes, é insuficiente ou mal executado nas cidades, apresentando imperfeições, precisando ser refeito, causando muitos problemas aos cidadãos.

Uma manutenção efetiva do pavimento e das outras infra-estruturas na área urbana pode aumentar bastante a vida em serviço e reduzir os custos para os usuários. Porém, o que se tem observado no Brasil é a ausência de um trabalho integrado entre as diversas áreas do serviço público municipal, que interferem no espaço da via pública, sendo que a gerência da infra-estrutura urbana de transportes é feita de maneira informal, baseada principalmente na experiência dos profissionais envolvidos e em decisões políticas (LIMA et al., 2004).

Assim, o uso de ferramentas da Logística de Serviços poderia auxiliar o serviço de remendos, aumentando sua eficiência, ou seja, procurando atender a todos os pedidos com um consumo menor de recursos por parte da empresa que efetua o serviço.

\subsection{Justificativa para a abordagem}

As panelas, em resumo, muito observadas nas ruas, avenidas e rodovias brasileiras causam diversos problemas aos cidadãos, tais como:

- Queda na velocidade nas vias;

- Quebras mecânicas;

- Aumento do consumo de combustíveis;

- Aumento do ruído;

- Aumento da emissão de poluentes na atmosfera.

O que se observa também, principalmente nas rodovias brasileiras, é que devido aos buracos nas vias, os motoristas muitas vezes são obrigados a fazer desvios para evitá-los, aumentando assim a distância a ser percorrida, como mostra a reportagem do jornal Estado de São Paulo no dia 05 de março de 2004 (Figura 1.3) . 


\section{Cidades}

\section{Destruídas, estradas aguardam verba federal}

Situacão depois das chuvas é pior nas Regióes

Norte eNordeste, once

Para motorista da Régis, buracos e 'atenção especial'

\section{$\mathbf{E}_{\mathrm{MMG}}$}

MOTORISTA

FAZ DESVIO

DE $100 \mathrm{KM}$

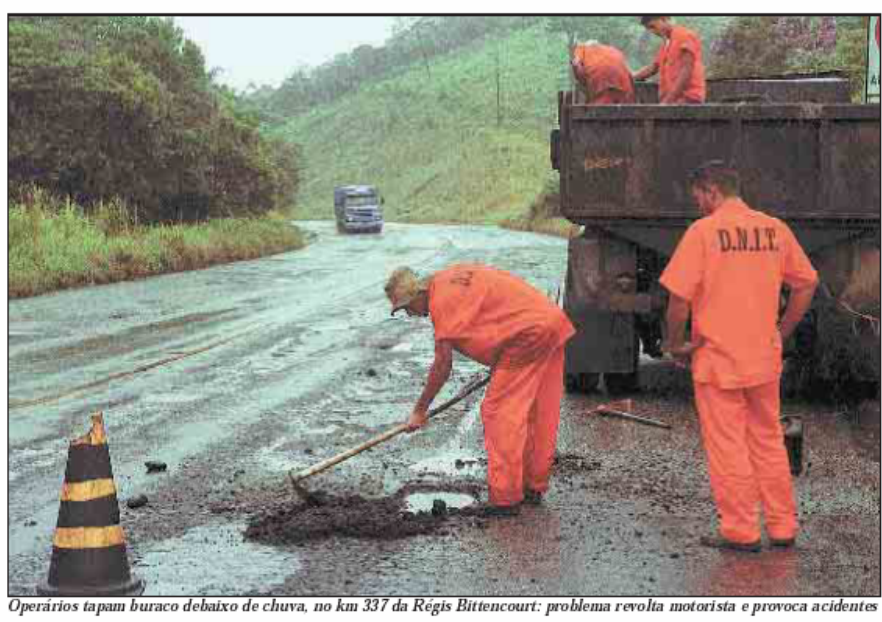

Figura 1.3 - Reportagem Estado de São Paulo - 0510312004

A reportagem também alerta para o quadro desalentador da malha rodoviária brasileira devido à falta de conservação e conseqüentemente a total perda da infra-estrutura em muitos trechos de rodovias.

Em outra reportagem (Figura 1.4), sobre os buracos na cidade de São Paulo, fica evidente a dificuldade da cidade, com uma extensa malha viária, em dar uma manutenção correta e ágil, chegando a prefeitura a admitir essa dificuldade.

\section{Cidades}
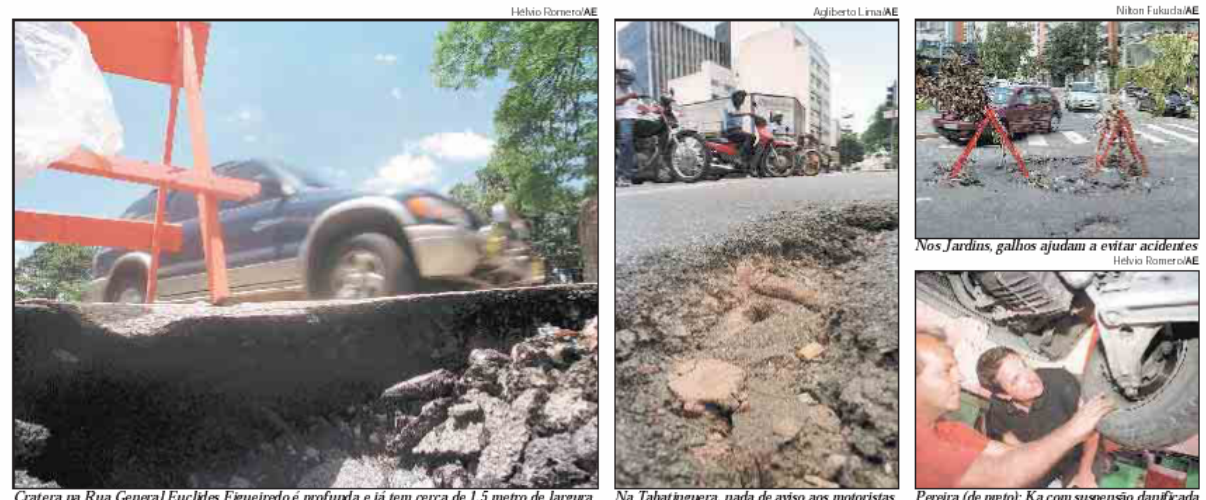

Depois das chuvas, ruas cheias de buracos

Figura 1.4 - Reportagem Estado de São Paulo - 2810212004 
As panelas não reparadas aumentam seu tamanho até comprometer completamente o pavimento, fazendo com que o custo do reparo da via seja muito maior.

Os diversos tipos de mídia reportam freqüentemente o problema dos buracos nas rodovias e vias urbanas brasileiras, principalmente na época das chuvas, quando a ocorrência de buracos é muito maior, mostrando como os usuários destas são diretamente afetados.

Porém o problema se estende também aos consumidores, pois os atrasos em congestionamentos, quebras e desvios acabam afetando o preço dos produtos. As empresas acabam tendo um custo de transporte elevado, pois o gasto com as quebras de veículos é maior, há a necessidade de uma frota maior para enfrentar as baixas velocidades de operação e os desvios nas rotas, como também ocorre um consumo maior de combustível.

\subsection{Objetivos gerais e específicos}

Esta dissertação tem como objetivo geral mostrar que os serviços públicos de uma cidade, como o serviço de tapa-buracos, cujo nome mais apropriado é remendo, pode ser abordado de uma forma racional, através da logística de serviços, para promover o aumento de sua eficiência e assim ter sua eficácia melhorada.

Os objetivos específicos, que são a observação da melhoria do serviço através da roteirização das equipes de remendos e da previsão por serviços de remendos são abordados através de um estudo de caso na cidade de São Carlos.

É utilizado um Sistema de Informações Geográficas - SIG para auxílio da gerência do serviço de remendos em pavimentos urbanos. Com base em um levantamento de campo sobre dimensões e localização das panelas, uma roteirização é feita com o auxílio do SIG TransCAD e os resultados obtidos são confrontados com os resultados reais, para se observar se ocorrem melhorias no tempo trabalhado e na quilometragem percorrida pelas equipes prestadoras do serviço. 
Também é estudada a estrutura que a prefeitura possui para a manutenção das vias da cidade, a quantidade do serviço executada nos últimos anos e a situação das vias.

Os dados obtidos na prefeitura são analisados, procurando-se observar se os recursos são aplicados na quantidade e tempo correto, e também é estudada a questão da previsão de demanda de remendos de acordo com a pluviosidade de cada época do ano.

\subsection{Escopo da dissertação}

Este capítulo introdutório apresentou ao leitor o problema das panelas nas vias, procurando mostrar como esse problema afeta os cidadãos e explicou os objetivos dessa dissertação.

O capítulo seguinte é usado para caracterizar o serviço de remendos em pavimentos e mostrar sua relação e importância para os sistemas viários das cidades.

São mostradas as diferentes etapas do serviço, contidas em manuais técnicos e é feita também uma relação com o serviço geralmente executado hoje nas cidades.

No capítulo 3 são apresentados alguns conceitos da Logística, especialmente a Logística de Serviços, suas diferenças com a Logística de Manufaturas, suas ferramentas e sua relação com os serviços urbanos.

A preocupação principal do capítulo 4 é mostrar uma possível aplicação do SIG no auxílio de um serviço urbano, além de exibir as demais qualidades de um SIG e suas utilidades na gerência urbana.

O quinto capítulo explica como os dados foram coletados e como foram relacionados. Explica também como foi elaborada a base de dados e o uso da rotina de roteirização da ferramenta escolhida.

O capítulo 6 contém um estudo de caso que procura explicar as características da cidade de São Carlos e a condição de suas vias.

É explicado também como é executado o serviço de remendos nos pavimentos da cidade: a contratação do serviço, o material e equipamento utilizado e as quantidades executadas nos últimos anos. 
No capítulo 7 são expostos, primeiramente, os resultados encontrados na coleta de dados e os principais problemas observados, como o excesso de remendos em algumas vias e o uso de roteiros incoerentes.

Em seguida são mostrados os resultados obtidos com o SIG TransCAD, inclusive são mostrados diversos mapas com as rotas elaboradas pelo programa, e os resultados são confrontados.

Os dados obtidos na prefeitura sobre a quantidade de remendos executados durante o período do último contrato e a pluviosidade no mesmo período são analisados à procura de uma relação entre as duas.

Então, finalmente, são sugeridas correções em algumas etapas do serviço de acordo com as dificuldades e falhas encontradas.

No capítulo 8 são expostas as conclusões alcançadas sobre o serviço e as ferramentas utilizadas na elaboração desta dissertação, como o uso do SIG para a gerência de um serviço urbano e o uso de ferramentas da Logística para a melhoria da eficiência deste serviço. São propostos também outros temas a serem pesquisados, de forma a contribuir com o assunto. 


\section{O SERVIÇO DE REMENDO EM PAVIMENTOS}

\subsection{As vias urbanas}

Parte importante da infra-estrutura de uma cidade são suas vias, ou sistema viário, que compreende uma ou mais redes de circulação para veículos, bicicletas, pedestres entre outros. O sistema viário é complementado pela rede de drenagem pluvial, que assegura o uso do sistema sob qualquer condição climática.

Para Mascaró (1989), de todos os sistemas, o viário é o mais delicado, pois:

- É o mais caro do conjunto de sistemas urbanos, normalmente representando mais de $50 \%$ dos custos de urbanização;

- Ocupa parcela importante do solo urbano (entre 20 e 25\%);

- É o sistema com maior dificuldade em aumentar a capacidade, por seus custos, espaço ocupado e pela dificuldade de operação;

- É o sistema mais vinculado aos usuários, pois transporta pessoas e não materiais, sendo assim mais evidente para quem faz uso dele.

Ainda segundo Mascaró (1989), para se obter uma economia significativa nos custos totais de infra-estrutura urbana, as alternativas escolhidas deverão ser observadas em todas as redes, mas especialmente as redes que constituem o sistema viário (pavimento e drenagem pluvial), por esse representar mais da metade do custo total. A Tabela 2.1 mostra a participação de cada rede no custo total de redes de infra-estrutura urbana. 
Tabela 2.1 - Participação percentual das redes no custo total da infra-estrutura urbana

\begin{tabular}{lcc}
\hline \multirow{2}{*}{ REDE } & \multicolumn{2}{c}{$\begin{array}{c}\text { Participação de cada rede no custo total de } \\
\text { redes de infra-estrutura (\%) }\end{array}$} \\
\cline { 2 - 3 } & $\begin{array}{c}\text { Áreas de baixa } \\
\text { densidade }\end{array}$ & $\begin{array}{c}\text { Áreas de alta } \\
\text { densidade }\end{array}$ \\
\hline Pavimento & 42 & 43 \\
Drenagem Pluvial & 14 & 16 \\
Abastecimento de Água & 4 & 4 \\
Esgoto Sanitário & 17 & 20 \\
Abastecimento de Gás Encanado & 9 & 9 \\
Abastecimento de Energia & 13 & 7 \\
Elétrica & 1 & 1 \\
Iluminação Pública & & \\
\hline
\end{tabular}

Fonte: Mascaró (1989)

A importância da pavimentação das vias urbanas para a maioria das pessoas, técnicos, políticos ou usuários, é bastante clara, embora por motivações diversas. No entanto, a fase seguinte, que é a da manutenção das vias construídas, não é tão evidente para a maioria, pelo menos àqueles que têm o poder decisório nas mãos, ao que parece, nos dias de hoje, na maioria das cidades e também das rodovias (MOTTA, 1995).

Oliveira (1994) comenta que o enfoque político, por questão cultural e estratégica sempre foi a realização de novas obras e não a manutenção das obras antigas, o que trouxe conseqüências graves ao sistema viário como sua degradação acentuada e esgotamento precoce da vida útil.

Villibor, Fortes e Fernandes (1993) também comentam que a maior preocupação dos administradores urbanos é a construção de pavimentos novos, no lugar da manutenção de rotina destes, pois novos pavimentos causam maior impacto político junto à população, trazendo um maior retorno político. 


\subsection{As atividades de manutenção e reabilitação de pavimentos}

Os pavimentos, sejam eles urbanos ou rodoviários, apresentam defeitos vindo da deterioração dos materiais que os compõem, necessitando, então, de atividades de manutenção e reabilitação para corrigir tais defeitos, procurando dar aos usuários as condições de circulação, segurança, conforto e economia, originalmente previstas em projeto.

Os principais serviços de manutenção executados em estradas e vias urbanas consistem, geralmente, em remendos, selagem de trincas e capas selantes.

As atividades de Manutenção e Reabilitação de pavimentos devem ser realizadas de forma contínua, devido ao constante aparecimento de defeitos, causados pelas solicitações impostas pelo tráfego e pelo meio ambiente (FERNANDES Jr., ODA e ZERBINI, 2001).

Souza (1993) define a manutenção das vias urbanas como uma atividade cotidiana, que utiliza considerável quantia de recursos tanto financeiros quanto de pessoal e cuja visibilidade aos olhos do munícipe usuário se faz sentir mais rapidamente do ponto de vista negativo, ou seja, ela é melhor percebida quando a manutenção é escassa ou ineficiente do que quando ela é realizada adequadamente.

De Senço (2001) explica que a execução do serviço de manutenção é feita por turmas devidamente equipadas para a execução praticamente imediata de reparos nas vias, obedecendo a três etapas:

- Localização do defeito;

- Determinação da causa;

- Execução do reparo.

As turmas de conservação têm autonomia para tomar em campo as decisões e as medidas necessárias para a correção do defeito, recorrendo à autoridade centralizada somente em caso de acidentes ou defeitos de difícil interpretação. 
A detecção e o reparo dos defeitos nas fases iniciais representam o trabalho mais importante desempenhado pela equipe de manutenção, ou seja, aquele que resulta na melhor utilização dos recursos disponíveis. As trincas, por exemplo, se não seladas logo, podem evoluir rapidamente para outros defeitos, aumentado, dessa forma, os custos de operação dos veículos e os custos de manutenção e reabilitação.

Atividades de manutenção procuram preservar ou manter o período de projeto do pavimento, aumentando pouco o nível de serventia, mas evitando a deterioração precoce.

O conceito de serventia (Figura 2.1), proposto por Carey e Irik em 1960, é uma avaliação subjetiva do pavimento, onde avaliadores treinados percorrem o trecho de pavimento a ser avaliado dando notas de 0 (péssimo) até 5 (ótimo).

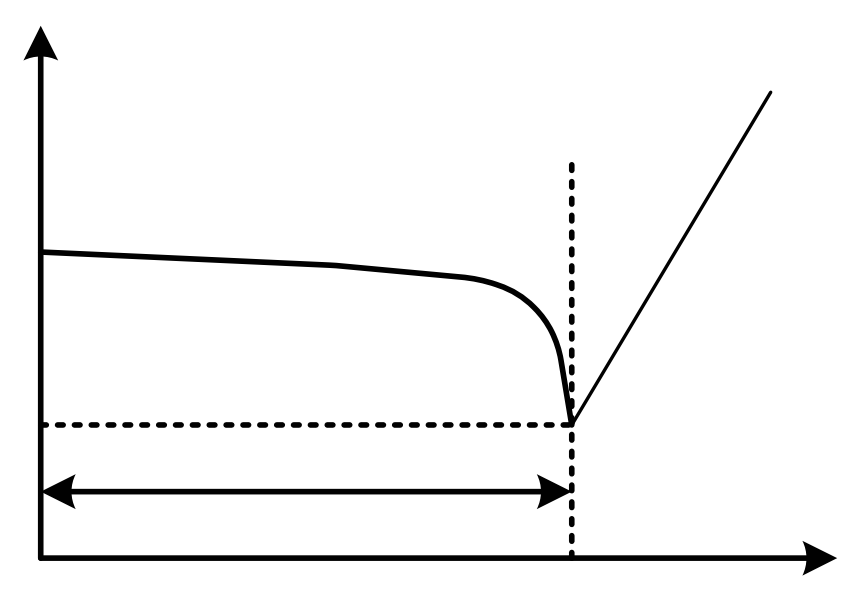

Figura 2.1 - Conceito de serventia - desempenho

Embora as atividades de manutenção ajudem a prolongar a vida em serviço, os pavimentos precisam, mais cedo ou mais tarde, de atividades de reabilitação. Quando o período de projeto ou o número de solicitações do tráfego é excedido, há a necessidade de atividades de reforço, que consistem de trabalhos mais efetivos, visando a recuperação de pavimentos deficientes.

A reabilitação procura prolongar a vida em serviço do pavimento, elevando o nível de serventia próximo ao valor máximo e criando condições para um novo ciclo de deteriorações. 
Atrasos nas atividades de manutenção e reabilitação quase sempre resultam em gastos adicionais, pois as estruturas dos pavimentos sofrem deterioração acelerada na medida em que ocorrem os adiamentos das intervenções (FERNANDES Jr., ODA e ZERBINI, 2001).

Porém, a Administração Pública possui várias outras demandas e variáveis para analisar ao escolher onde aplicar suas verbas, equipamentos e funcionários, geralmente insuficientes, o que leva à falta de recursos para os trabalhos de manutenção das estruturas existentes, principalmente das vias.

Com a escassez de recursos nem todas as vias podem ser mantidas com o mesmo nível, levando a Administração Pública a priorizar certas regiões e vias da cidade.

Salmi et al. (1996) mostram que o município de São José dos Campos priorizava a manutenção das vias por onde passavam os coletivos urbanos, a não ser em casos de emergência como erosões e deslizamentos, por considerar que o usuário de automóvel é o maior responsável pela ocupação do espaço do sistema viário.

As preocupações com cortes no orçamento para a manutenção de vias e em como aplicar esses recursos não são recentes e não acontecem somente em países pobres.

O trabalho de Al-Shawi, Cabrera e Watson (1987) mostrou que os cortes contínuos nos investimentos em manutenção levaram os engenheiros franceses a procurar sistemas de suporte a decisão para assisti-los na determinação da melhor maneira de gastar os recursos disponíveis.

Hoje em dia, o Sistema de Gerência de Pavimento - SGP é usado para auxiliar tecnicamente engenheiros e administradores públicos. O SGP define qual a melhor estratégia a ser adotada, qual tipo de serviço de manutenção ou reabilitação deve ser utilizado (não fazer nada, manutenção corretiva, manutenção preventiva, reforço estrutural ou reconstrução), quando e onde o serviço é necessário. Assim, o SGP ajuda na tomada de decisão levando a um maior retorno do investimento do dinheiro disponível. 


\subsection{A execução dos remendos}

Os pavimentos, com o decorrer do tempo, acabam apresentando buracos, definidos como panelas, resultado da ação combinada de umidade e tráfego ou em virtude da abertura de trincheiras para construção e execução de reparos das redes de água, gás, esgoto, telefone, energia elétrica etc.

De acordo com artigo de Lima et al. (2004), contendo um estudo de caso sobre gerência de pavimentos para a cidade de São Carlos, a influência do SAAE (Serviço Autônomo de Água e Esgoto) nos pavimentos da cidade é alta (mais de um terço das seções de pavimentos estudadas).

Zanchetta (2005) descreve o problema de panelas como um dos defeitos mais presentes nas vias de São Carlos, ocorrendo em 4548 seções de um total de 7113 seções estudadas em diversas localidades da cidade.

Bertollo (1997) recomenda que os buracos devem ser imediatamente reparados, pois comprometem a segurança e o conforto e aumentam os custos operacionais. Além disso, permitem a entrada de água, que enfraquece a estrutura do pavimento e acelera sua deterioração.

Para reparar os diversos defeitos do pavimento, principalmente as panelas, as prefeituras mantêm equipes ou contratam empresas para efetuar o serviço comumente chamado de "tapa-buracos".

Porém, tal termo técnico se mostra incorreto, uma vez eu ele transmite a impressão de que a panela no pavimento é somente preenchida com massa asfáltica, sem a correta compactação. O termo técnico apropriado para esse serviço seria remendo, definido como um reparo no pavimento onde há a necessidade de abertura de caixa, utilizando-se equipamentos de corte vertical.

Para a execução dos remendos, podem ser usados dois tipos de misturas asfálticas: o CBUQ (Concreto Betuminosos Usinado a Quente), que usa o CAP (Cimento Asfáltico de Petróleo) aquecido ou o PMF (Pré Misturado a Frio), que utiliza a emulsão asfáltica. 
Segundo a ABEDA (2001), o serviço de remendos com emulsões asfáltica é o sistema mais simples para a conservação de pavimentos e é comumente empregado em planos emergenciais de reparos em vias urbanas e rurais.

A ABEDA (2001) destaca, ainda, as principais vantagens do uso das emulsões:

- Dispensa qualquer aquecimento;

- Apresenta excelente adesividade;

- Possibilita o trabalho com agregados úmidos;

- Pode ser produzido em simples betoneiras;

- Permite a estocagem da mistura, possibilitando a usinagem dissociada da aplicação na pista;

- É de técnica simples, podendo ser praticada por pessoal sem grande experiência;

- Possibilita a realização de serviços mais econômicos.

Já o CBUQ necessita do uso de maquinário e pessoal especializado, como aquecimento dos agregados e do CAP, e a mistura asfáltica não permite a estocagem, nem a aplicação sob clima desfavorável.

Porém, alguns autores como Fernandes Jr., Oda e Zerbini (2001), recomendam o uso do CBUQ para reparos, devido às observações práticas onde este apresenta uma durabilidade maior, deixando o uso do PMF para reparos emergenciais, executados sob condições climáticas desfavoráveis.

Além do material escolhido, deve-se escolher também o método a ser utilizado para o serviço.

Bertollo (1997), apresenta três métodos diferentes:

- O "simples lançamento" da mistura asfáltica, método mais utilizado, não só no Brasil. Não constitui uma técnica adequada, mas apresenta alta produtividade; 
- O "simples lançamento" acrescido da compactação com o uso dos pneus do próprio caminhão que transporta a mistura;

- O reparo permanente, com o uso de corte vertical,.da área afetada do pavimento;

Ainda, segundo Bertollo (1997), o método permanente apresenta uma produtividade muito menor e requer um número de funcionários muito maior que os outros dois métodos.

Contudo, um estudo desenvolvido pelo corpo de Engenheiros do Exército dos Estados Unidos demonstra que o remendo permanente possui um custo por tonelada da ordem de três vezes menor que o custo do "tapaburaco".

Isso ocorre porque o remendo, apesar de possuir um custo maior de construção, é mais vantajoso a médio e longo prazo, em razão da diminuição do custo de mão-de-obra e equipamentos, redução da necessidade de novos remendos num mesmo local e manutenção do pavimento em boas condições por um período de tempo maior.

Para a execução de remendos permanentes nos pavimentos asfálticos, cada órgão possui seu manual, contendo o memorial descritivo deste serviço, como o manual do DERSA (1988), que descreve a execução do serviço de remendos da seguinte maneira, também ilustrada na Figura 2.2:

- Sinalização do local de trabalho;

- Demarcação do local a ser reparado (contorno do recorte);

- Corte dos bordos com rompedor pneumático ou similar. O corte deve ser de 20 a 30 centímetros além da extremidade do buraco em forma retangular, e deve atingir uma profundidade com material consistente;

- Remoção do material resultante da abertura da caixa;

- Limpeza da cavidade de forma a deixá-la seca e limpa. Se a causa da panela for a presença de água, deve-se instalar equipamento de drenagem; 
- Execução da pintura de ligação com emulsão asfáltica, tipo RR1C ou RR-2C nas paredes e fundo da caixa;

- Preenchimento da cavidade com CBUQ, com espessura máxima de $6 \mathrm{~cm}$;

- Compactação final do remendo (a superfície deve estar nivelada em relação ao pavimento adjacente). Quando a profundidade for superior a $15 \mathrm{~cm}$, a compactação deve ser realizada em camadas;

- Limpeza da área, retirada de equipamentos, sinalização e liberação do tráfego.

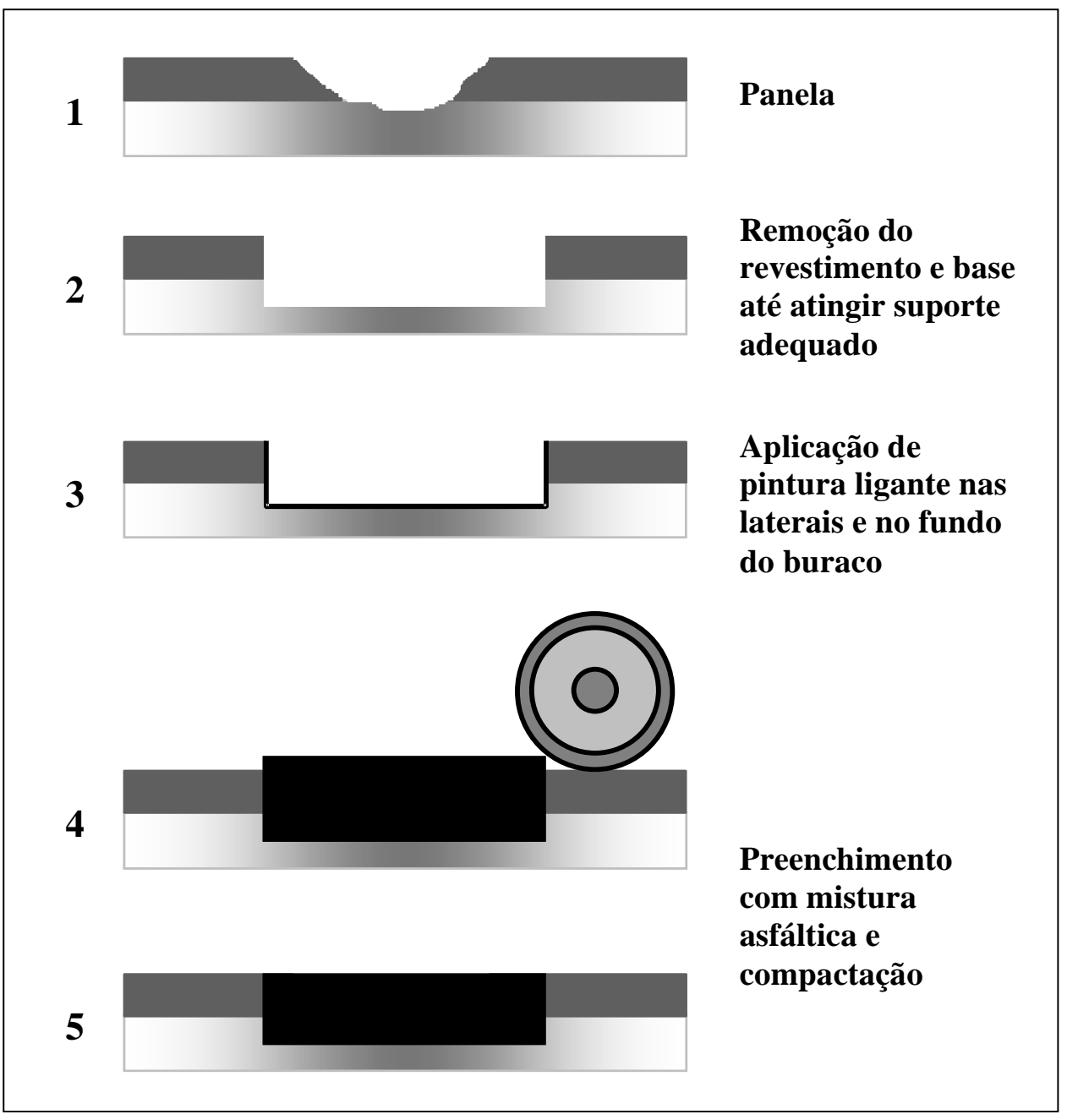

Figura 2.2 - Procedimentos para execução de um remendo permanente Fonte: Bertollo (1997) 
Para a execução dos serviços são necessários os seguintes recursos:

Mão de Obra:

> 01 Mestre de obra a cada três equipes;

> 01 Encarregado de obras por equipe;

> 02 Rasteleiros por equipe;

> 08 Serventes por equipe.

Equipamentos:

> 01 Caminhão basculante com capacidade para 10 t;

> 01 Caminhão carroceria com capacidade para 8 t e acessórios para o transporte de pessoal;

> 01 Rolo liso vibratório autopropulsor de 2 t, com carreta para transporte;

$>01$ Compressor de ar;

$>02$ Rompedores;

> 01 Caminhão Espargidor com capacidade para 5.000 I;

> 20 cones para sinalização;

$>01$ bandeira vermelha;

$>$ Ferramentas diversas como: vassourões, regadores, brochas soquetes, pás, enxadas, rastelos, carrinhos de mão, picaretas, etc.

Materiais:

Quantidades suficientes de:

$>$ Emulsão RR-1C ou RR-2C;

$>$ CBUQ.

O serviço é medido em metros cúbicos de mistura betuminosa aplicada e a produção diária é em média de 10 toneladas de CBUQ aplicado e acabado por equipe. 
Porém, o que acontece na maioria das vias urbanas e rodovias brasileiras estaduais e federais é uma realidade muito diferente. O que se observa é a execução de "tapa-buracos" por "simples lançamento", muitas vezes com as panelas sendo preenchidas sujas ou com água no seu interior.

As equipes que realizam o serviço também são mais enxutas, muitas vezes compostas por um caminhão basculante, que carregam a mistura asfática, um tambor contendo a emulsão asfáltica e as ferramentas necessárias (pás, enxadas e forcados). O número de funcionários envolvidos na tarefa também é muito menor (geralmente três ou quatro funcionários). 


\section{LOGÍSTICA}

\subsection{A Logística}

A Logística era definida como a provisão de bens e serviços de um ponto de oferta para um ponto de demanda, como afirmam Eilon, Attson-Gandy e Christofides (1971).

Porém, hoje em dia, a Logística é definida como o processo de planejamento, implementação e controle do fluxo eficiente e economicamente eficaz de matérias primas, estoques em processo, produtos acabados e informações relativas desde o ponto de origem até o ponto de consumo, com o propósito de atender às exigências dos clientes, segundo o Council of Logistics Management - CLM ${ }^{1}$ (2001 apud Ballou 2001).

Esse conceito mais moderno leva em consideração não somente o correto fornecimento de matérias primas e o controle de entrega e estoque de produtos finais, mas também a contribuição financeira e o alcance da satisfação dos clientes através da Logística.

A importância econômica da Logística pode ser mais bem observada através de Ballou (1993), que mostra que os custos logísticos de produtos representam cerca de $23 \%$ do PNB nos Estados Unidos, sendo que o transporte representa em torno de dois terços deste custo.

Um produto ou serviço possui seu valor associado a quatro atributos: forma, posse, tempo e lugar.

A forma, no caso de um produto, é o formato que ele adquire após a montagem de seus componentes e peças, enquanto que para um serviço é a

${ }^{1}$ Council of Logistics Management (2001) apud BALLOU, R.H. (2001). Gerenciamento da Cadeia de Suprimentos. Porto Alegre: Bookman. 
combinação de um pacote de vários outros serviços ou de um serviço que atenda à expectativa ou desejo de um cliente.

A posse informa aos clientes em potencial a disponibilidade de um serviço ou produto para a sua aquisição.

Uma das funções do marketing é mostrar aos clientes em potencial os produtos e serviços de uma empresa, ou seja, suas características, formas e qualidades, mostrando também onde, como e em que condições adquirir tais mercadorias.

A logística se encarrega de entregar tais produtos e serviços em seu tempo e local correto, ou seja, quando e onde eles são desejados. Portanto, a logística assegura a satisfação do cliente coordenando o tempo de entrega, localização de estoques e outros serviços pertinentes.

Variações nesses quatro atributos podem afetar diretamente a receita de uma empresa. Portanto, a alteração dos atributos de forma, posse, tempo e lugar em uma empresa são aceitos apenas se os clientes concordam em pagar por tais modificações.

Assim, segundo Pelizaro (2000), a preocupação da Logística está relacionada ao transporte e à distribuição física de produtos e serviços, buscando cada vez mais o aprimoramento da qualidade e produtividade, através do melhor aproveitamento da frota existente, levando-a a executar percursos menores e mais rentáveis, não deixando de atender às exigências dos clientes com relação aos prazos, datas e horários de entrega.

\subsection{Logística de Serviços}

O setor de serviços compreende uma grande extensão de indústrias, como a do entretenimento, alimentação, tratamento de saúde, financeiro, transporte e distribuição, educação e serviços profissionais. Essa diversidade dificulta generalizações de conceitos, no que diz respeito à administração de todas as empresas de serviços. No entanto, muitas características subjacentes, que são similares nos serviços, são geralmente muito diferentes daquelas em 
outros setores da economia (por exemplo, manufatura, mineração, agricultura) (COOK ${ }^{2}$ et al., 1999. apud VERMA, 2001)

Ballou (2001) argumenta que serviço ao cliente é um termo muito amplo, que pode incluir muitos elementos, indo desde a disponibilidade de produtos à manutenção pós-venda. Na perspectiva da logística, serviço ao cliente é o resultado de todas as atividades logísticas ou do processo da cadeia de suprimentos.

Bowersox e Closs (2001) mostram que a logística de serviços ao cliente depende do conhecimento de quem é o cliente, que pode ser desde uma pessoa a um distribuidor ou outra empresa, e quais são as suas necessidades.

Com o conhecimento de quem é o cliente e quais suas necessidades, uma empresa pode traçar sua estratégia de marketing para alcançar lucros e mercados, pois o marketing se baseia no seguinte trinômio:

- Os produtos ou serviços (ou sua combinação) devem satisfazer às necessidades do cliente;

- Produtos e serviços têm valor apenas quando disponíveis - os clientes devem poder obter prontamente os produtos desejados, e para isso a empresa deve estar preparada a dirigir todos seus recursos para fornecer tais produtos;

- A rentabilidade é mais importante que o volume de vendas - para uma empresa particular o que importa é maximizar o lucro, mesmo que isso signifique atender somente a uma parcela do total de clientes disponíveis no mercado.

\subsubsection{Diferença da Logística de Manufaturas}

As características próprias dos serviços, como as citadas acima, fazem com que a Logística de Serviços seja diferente da Logística de Manufaturas.

${ }^{2}$ COOK et al. (1999).Services Typologies: A State of the art survey. Production and Operations Management, 8, p.318-338 apud VERMA, R. (2001). Services Marketing. Amsterdam: Pregamon. 
Segundo Verma (2001), uma empresa de serviços agrega valor aos consumidores com nenhuma ou com transformações relativamente pequenas de materiais.

Para Hesket e Evans (1994), a Logística de Serviços têm seu foco no suprimento de produtos que não existem fisicamente e apresenta diferenças importantes em relação à Logística de Manufaturas.

$\mathrm{Na}$ Logística de Serviços os consumidores muitas vezes podem ser vistos não somente como consumidores, mas também como provedores de outros serviços e até mesmo como "estoque".

Para uma empresa de serviços, a localização é muito mais importante do que para uma empresa de manufatura. Um serviço não existe fisicamente para ser estocado, sendo "produzido" onde é requerido pelo consumidor, ao contrário dos produtos manufaturados que podem ser estocados e transportados até onde são necessários.

Além da preocupação com os custos operacionais, existe também a preocupação com a característica perecível dos serviços. Uma vez que os serviços são produzidos, eles devem ser consumidos de imediato, ou seja, eles devem chegar aos cidadãos que os necessitem num determinado tempo e local correto.

Por exemplo, um ônibus da rede pública de transporte urbano que chega a um determinado ponto de passageiros. Se não houver nenhum passageiro naquele instante para consumir o serviço de transporte oferecido pelo ônibus, a viagem (ou serviço) foi perdida.

Uma característica do setor de serviços é que ele está mais concentrado nas áreas urbanas. Por causa de algumas estratégias logísticas que são realizadas nos centros urbanos, como o "just-in-time", em que peças ou serviço são requeridos no momento de sua utilização, dispensando-se assim a necessidade e os custos dos estoques, alguns problemas com congestionamentos e problemas ambientais, como aumento da poluição, são enfrentados.

A informação é considerada crítica para uma empresa de serviços. Em particular, dados experimentais são a razão do sucesso de muitas empresas de 
serviços. Uma vez que os serviços não podem ser estocados, o conhecimento de quem é o cliente, quais suas expectativas e, principalmente, a variação da demanda com o tempo e a variação da receita com o nível de serviço oferecido, são importantes na correta alocação de recursos.

Em muitos serviços existem algumas diferenças no papel das redes e no planejamento e administração dessas redes. No setor de serviços, essas redes podem compreender instalações físicas em empresas de transportes, informação para empresas de computação e comunicação e relacionamento pessoal com os clientes para empresas de serviços de investimentos e bancos.

Outra diferença exposta por Hesket, Sasser Jr. e Hart (1994) é que os resultados de um serviço são difíceis de se avaliar antecipadamente, ao contrário de um produto. Antes de comprar um produto, este pode ser avaliado e até testado, o que não pode ser feito com um serviço.

Porém, com o uso dos computadores e programas especialmente desenvolvidos, muito comuns atualmente, podem ser feitas simulações de certos serviços, diminuindo a dificuldade de avaliação antecipada, como descrito no parágrafo anterior.

\subsection{Efeito do nível de serviço sobre as vendas}

Cada vez que uma empresa aumenta o nível de serviço aos clientes, as suas vendas aumentam. Porém, nem sempre incrementos no nível de serviço trazem aumentos de vendas em iguais proporções.

Alvarenga e Novaes (2000) afirmam que o prazo de entrega, avarias na carga, extravios e reclamações diversas são os principais componentes do nível de serviço, sendo que, de todos os fatores, o que os clientes consideram mais importante é o prazo de entrega.

A curva a seguir (Figura 3.1) representa o aumento de vendas de um produto ou serviço à medida que o nível de serviços aumenta em relação a uma empresa concorrente.

São identificados três estágios diferentes na curva: limiar, retorno decrescente e declínio. 
- Limiar: primeira região da curva. O início desse estágio representa empresas que apresentam produtos idênticos quanto a preço e qualidade. A partir desse ponto, qualquer incremento que uma empresa faça no nível de serviço em relação à concorrência, traz um aumento nas vendas pela "captura" dos clientes das empresas concorrentes;

- Retornos decrescentes: a maioria das empresas opera seus sistemas logísticos nessa região. Nesse estágio, os aumentos dos níveis de serviços não são totalmente percebidos pelos compradores e, portanto, não trazem retornos de mesmas proporções nas vendas;

- Declínio: é quando a melhoria no serviço é levada ao extremo, resultando no declínio das vendas. A queda nas vendas ocorre porque os clientes acabam saturados de informações e ofertas dos fornecedores.

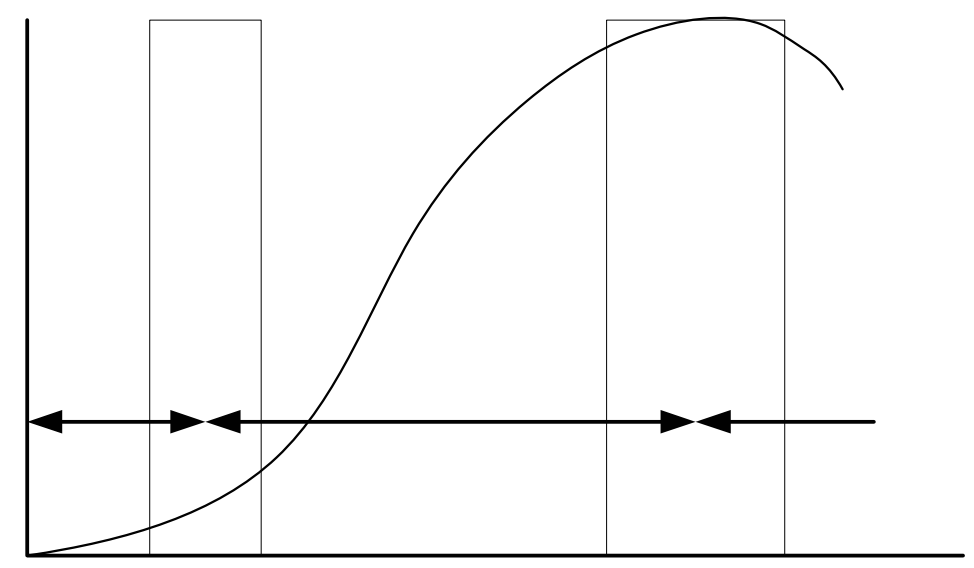

Figura 3.1 - Relação entre vendas e serviço ao cliente

Quando os níveis de atividades aumentam para satisfazer níveis mais elevados de serviço ao cliente, os custos aumentam a uma taxa crescente. Esse é um fenômeno observado na maioria das atividades econômicas, quando são realizadas além do ponto de máxima eficiência. Os retornos decrescentes na relação venda-serviço e o aumento na curva de custo-serviço resultam em uma curva de lucros mostrada na Figura 3.2. 
Assim, ganhar competitividade por meio de oferta de serviços de qualidade, não significa oferecer elevados níveis de serviço indiscriminadamente para todos os clientes (Figueiredo, 2000).

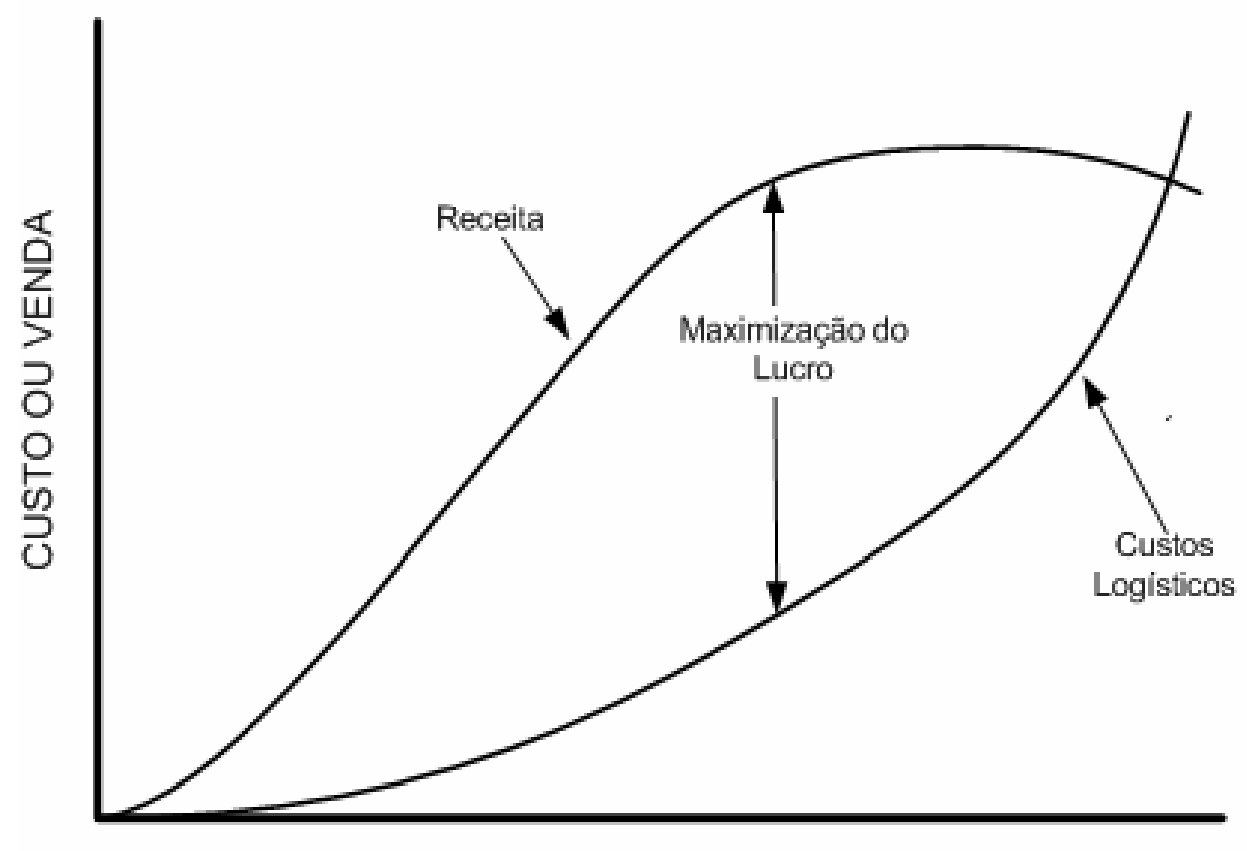

\section{Nível de Serviço Logistico}

Figura 3.2 - Compensações gerais no custo-receita em vários níveis de serviço logístico aos clientes.

Alguns clientes não percebem ou não valorizam tal aumento do nível de serviço, o que só torna o processo mais oneroso, sem que ele seja percebido como diferenciado.

Através da Figura 3.3 (curva $A B C$ ) observa-se, também, que alguns clientes, somente $20 \%$, contribuem para o lucro da empresa, representando $80 \%$ do volume de vendas, enquanto outros, os clientes com menores volumes de venda, contribuem muito pouco ao lucro ou até apresentam margem de contribuição negativa, diminuindo os lucros.

Portanto, observa-se que as empresas procuram trabalhar em um nível de serviço tal que seus lucros sejam maximizados, ou, às vezes, com lucros um pouco menores, porém com um volume de vendas maior e assim com uma maior participação no mercado, oferecendo bons níveis de serviços a determinados grupos de clientes, que trazem maior rentabilidade à empresa. 


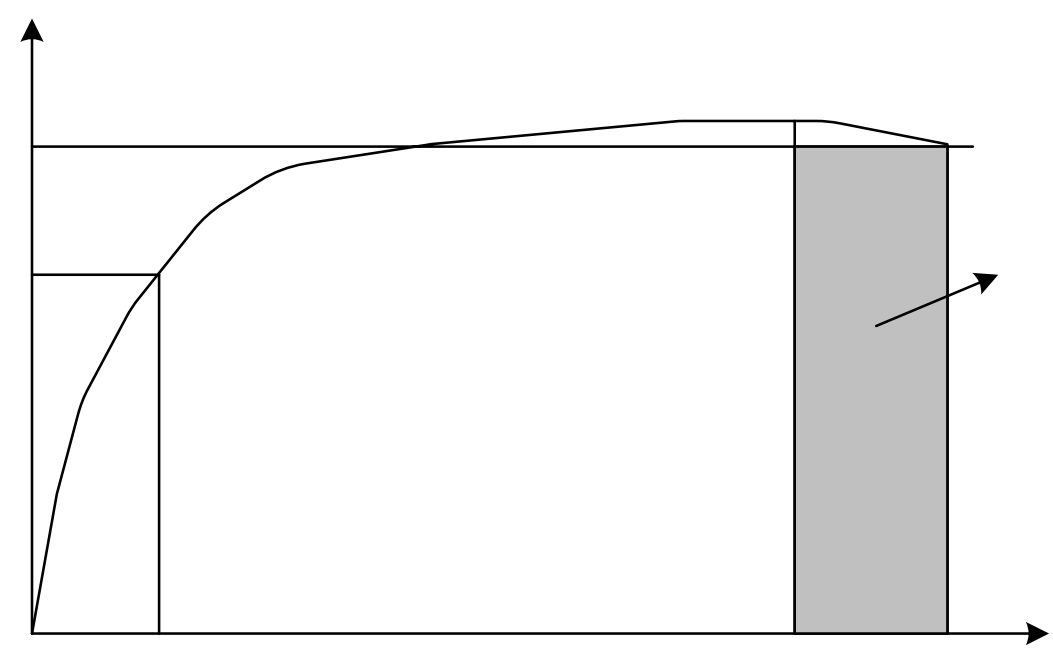

Figura 3.3 - Rentabilidade de uma carteira de clientes

\subsection{Níveis de planejamento: estratégico / táticol operacional}

Com o conhecimento de quem é o cliente e quass 50 suas

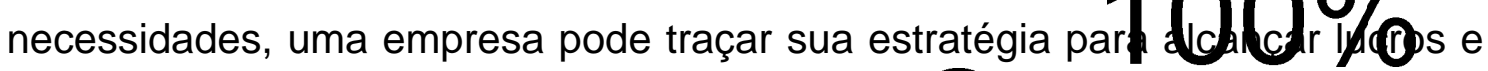
mercados atendendo às exigências dos seus clier.

Porém, para Dornier et al. (2000), quando chraga à estratégia logística, a maioria das funções de operações e logístic permanece relegada aos tradicionais papéis reativos táticos. A alta direch̆o enxerga speracões e logística como tática por natureza, projeta a estratégia enorefofio sem considerar as estratégias logísticas, relegando-lhẹ um papel de minimização de custos. No entanto, para se alcançar os opjgivos de uma empresa, é necessário também traçar uma estratégia logística

O planejamento logístico tenta responder aos questionamentos de o que, quando, como, nos níveis estratégico, tá e operacional (BALLOU, 2001), ou seja, um planejamento de lon médio e curto prazo, respectivamente.

A Tabela 3.1 mostra alguns exemplos dedalisões estratégicas, táticas e operacionais na Logística. 
Tabela 3.1 - Exemplo de tomada de decisões estratégicas, táticas e operacionais

\begin{tabular}{|c|c|c|c|}
\hline \multirow[b]{2}{*}{ Tipo de decisões } & \multicolumn{3}{|c|}{ Níveis de decisão } \\
\hline & Estratégia & Tática & Operacional \\
\hline Localização & $\begin{array}{l}\text { Número de locais, } \\
\text { tamanho e localização }\end{array}$ & $\begin{array}{l}\text { Posicionamento dos } \\
\text { estoques }\end{array}$ & $\begin{array}{l}\text { Roteirização, } \\
\text { aceleração e despacho }\end{array}$ \\
\hline Transportes & Seleção de modos & $\begin{array}{c}\text { Sazonalidade do mix } \\
\text { de serviço }\end{array}$ & $\begin{array}{l}\text { Quantidade e tempo } \\
\text { de reabastecimento }\end{array}$ \\
\hline $\begin{array}{l}\text { Processamento de } \\
\text { pedidos }\end{array}$ & $\begin{array}{l}\text { Seleção e projeto do } \\
\text { sistema de colocação de } \\
\text { pedidos }\end{array}$ & $\begin{array}{l}\text { Regras de prioridades } \\
\text { para pedidos e } \\
\text { clientes }\end{array}$ & Aceleração de pedidos \\
\hline Serviços ao cliente & $\begin{array}{l}\text { Estabelecimento de } \\
\text { padrões }\end{array}$ & & \\
\hline Armazenagem & Leiaute, seleção de local & $\begin{array}{c}\text { Escolha sazonal de } \\
\text { espaço }\end{array}$ & $\begin{array}{l}\text { Preenchimento de } \\
\text { pedidos }\end{array}$ \\
\hline Compra & Políticas & $\begin{array}{l}\text { Contratação, seleção } \\
\text { de fornecedor }\end{array}$ & Liberação de pedidos \\
\hline
\end{tabular}

Fonte: Ballou (2001)

O estabelecimento de uma política de manutenção dos pavimentos de uma cidade, com o estabelecimento da qualidade aceitável desses pavimentos e, conseqüentemente, a determinação das quantidades de serviços e materiais que serão contratados durante um horizonte de tempo, são características de uma decisão estratégica.

Tal decisão leva em conta diversos fatores como padrões aceitáveis de manutenção, condições atuais dos pavimentos, verba disponível ou desejável para a manutenção etc.

O uso da Pesquisa Operacional, especialmente nesse caso a Programação Dinâmica, aliada à posse de dados confiáveis sobre 0 aparecimento de panelas, poderiam auxiliar na decisão.

Wagner (1986) descreve a Pesquisa Operacional como sendo uma abordagem científica à resolução de problemas para a administração executiva. A aplicação da Pesquisa Operacional envolve:

- A construção de modelos matemáticos, econômicos e estatísticos do problema tratado, considerando suas complexidade e incerteza; 
- A análise das relações que determinam as conseqüências futuras de cada ação tomada, assim como o cálculo das vantagens adquiridas em cada uma dessas ações.

A Programação Dinâmica, em especial, se preocupa em estabelecer quais condições devem ser satisfeitas no decorrer de um período de tempo em que o problema está sendo analisado, a fim de se alcançar um resultado ótimo de seu objetivo, sendo que as condições do problema se alteram no decorrer deste tempo.

A aplicação da Programação Dinâmica ao problema de remendos em pavimentos urbanos seria válida, pois:

- A cidade possui panelas antigas que precisam ser remendadas, além das novas que surgem com o tempo;

- As panelas aparecem de acordo com as chuvas e a idade do pavimento, portanto seu aparecimento possui um caráter sazonal;

- A prefeitura possui recursos (orçamento) limitados para realizar os serviços de remendos.

Assim, é necessário um planejamento adequado dos recursos disponíveis, para que se alcance o objetivo final de remendar todas as panelas que existiam anteriormente e, também, para remendar todas as novas panelas que aparecem no decorrer do tempo, sem ultrapassar o orçamento ou a capacidade das equipes.

Para ilustrar o uso da Programação Dinâmica, é dado um exemplo, baseando-se em condições enfrentadas na realidade.

A prefeitura deveria remendar todas as panelas que existiam anteriormente, num certo período de tempo (horizonte de planejamento), além, é claro, das panelas que surgirão durante esse período, que podem ser determinadas com o uso da relação de previsão de demanda explicada anteriormente.

A prefeitura, também, não pode exceder nem diminuir as quantidades contratadas de insumos e serviços, que por lei não pode variar mais que $25 \%$ para mais ou para menos, assim como não é desejável exceder a capacidade 
da usina de PMF da Prefeitura (capacidade do maquinário e/ou dos insumos comprados).

Então as variáveis de decisão do problema seriam:

$\mathrm{d}_{\mathrm{t}}=$ número de remendos feitos no período $\mathrm{t}$;

$x_{t}=$ Porcentagem de panelas pré-existentes remendadas no período $t$;

$\mathrm{V}_{\mathrm{t}}=$ Verba para a execução dos serviços no período $\mathrm{t}$;

$\mathrm{C}_{\mathrm{t}}=$ Capacidade para produção de PMF.

A restrição de se remendar as panelas que surgem, mais certa quantidade pré-existente, por trimestre $\left(\mathrm{x}_{\mathrm{t}}\right)$, onde $\mathrm{q}_{0}$ representa a quantidade de panelas pré-existentes e $q_{t}$ representa a quantidade de panelas que surgiram no período t, é dada por:

$$
d_{t} \leq x_{t} \cdot q_{0}+q_{t}
$$

Não é desejável que a capacidade de produção de PMF seja ultrapassada, pois isso significaria a necessidade de compra de mais insumos no período (agregados e emulsão asfáltica) ou que a produção estaria além da capacidade nominal da usina. Portanto:

$$
d_{t} \leq C_{t}
$$

$\mathrm{E}$, também, as quantidades executadas devem estar entre o intervalo de variação do contrato:

$$
0,75 V_{t} \leq d_{t} \leq 1,25 V_{t}
$$

Finalmente, a função objetivo é dada como:

$$
\operatorname{MIN}\left(j_{t} d_{t}\right)
$$

onde $\mathrm{j}_{\mathrm{t}}$ representa o custo no período t para se efetuar uma unidade de remendo.

Esse modelo simples serve para ilustrar como a situação real poderia ser expressa matematicamente, sob o ponto de vista da prefeitura. Ele serve, também, para uma análise maior, pois a mudança de qualquer uma das variáveis de decisão (por exemplo, aumentando a capacidade $\mathrm{C}_{t}$ da usina ou a verba $\mathrm{V}_{\mathrm{t}}$ do período) muda o resultado final, e o modelo permite a análise das vantagens adquiridas com essas mudanças. 


\subsection{Previsão de demanda}

Hesket, Sasser Jr. e Hart (1994) afirmam que um dos fatores do sucesso em muitos serviços é o grau de utilização da capacidade disponível, pois a qualidade de um serviço e os lucros da empresa têm relação com a capacidade utilizada da empresa, como mostra a Figura 3.4:

Demandas acima da capacidade ótima de utilização (instalações e funcionários) afetam a qualidade dos serviços executados, pois não haverá recursos disponíveis suficientes para atender a todos os pedidos, diminuindo assim o nível de serviço ao cliente $\mathrm{e}$, conseqüentemente diminuindo a qualidade deste serviço e futuramente diminuindo as vendas.

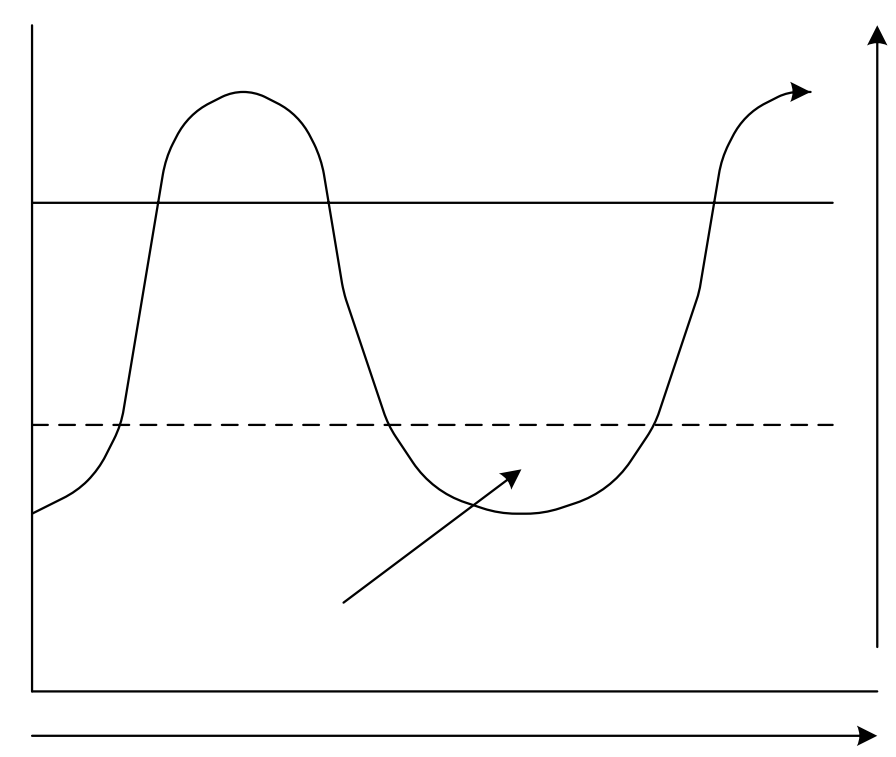

Figura 3.4 - Implicações da variação da demanda com relação à capacidade

Já, o uso abaixo da capacidade disponível gera desperdício de recursos, com baixo ou nenhum retorno do capital investido.

Para Bowersox e Closs (2001), a programação e o controle da produção e o planejamento da capacidade das instalações dependem de previsões precisas. Tais previsões e, conseqüentemente, a correção do planejamento, permitem que os recursos sejam alocados antecipadamente, como mostra a Figura 3.5. As previsões permitem equilibrar as demandas por recursos e minimizar onerosos picos, tanto de capacidade quanto de estoque. 


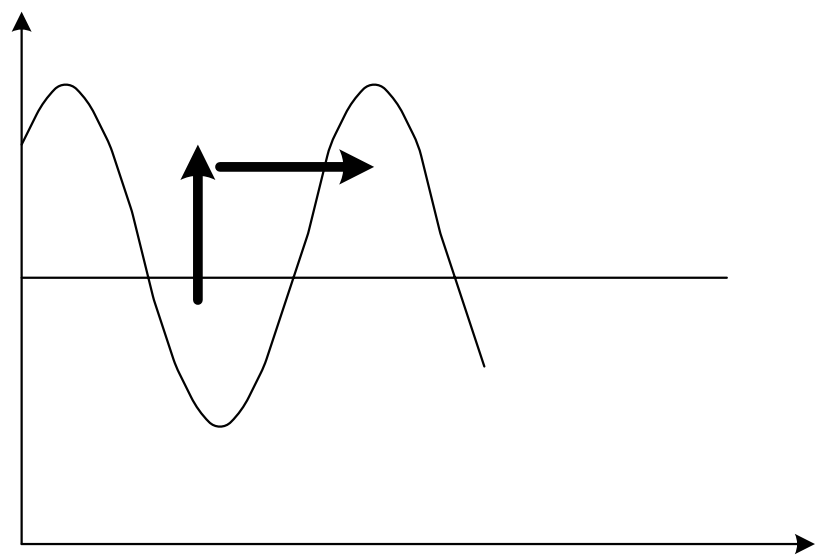

Figura 3.5 - Minimização de picos de demanda

Para Wanke (2000), a previsão de demanda tem importância especial no setor de serviços, pois nesse setor é impossível fazer um colchão amortecedor, como mostrado na Figura 3.5, contra as incertezas do mercado, devido à impossibilidade de se estocar serviços.

Assim, empresas de serviços possuem duas preocupações quando vão dimensionar sua capacidade operacional: o volume de capacidade adicional e o período quando essa adição deve ser efetuada.

Com uma previsão detalhada das necessidades futuras por serviços e com uma análise detalhada entre as vantagens de se manter a capacidade em excesso (ou ociosa) e o custo pela falta de capacidade (vendas perdidas), as empresas de serviços podem determinar o momento adequado para se incrementar a capacidade, com base em três diferentes políticas, como mostra a Figura 3.6:
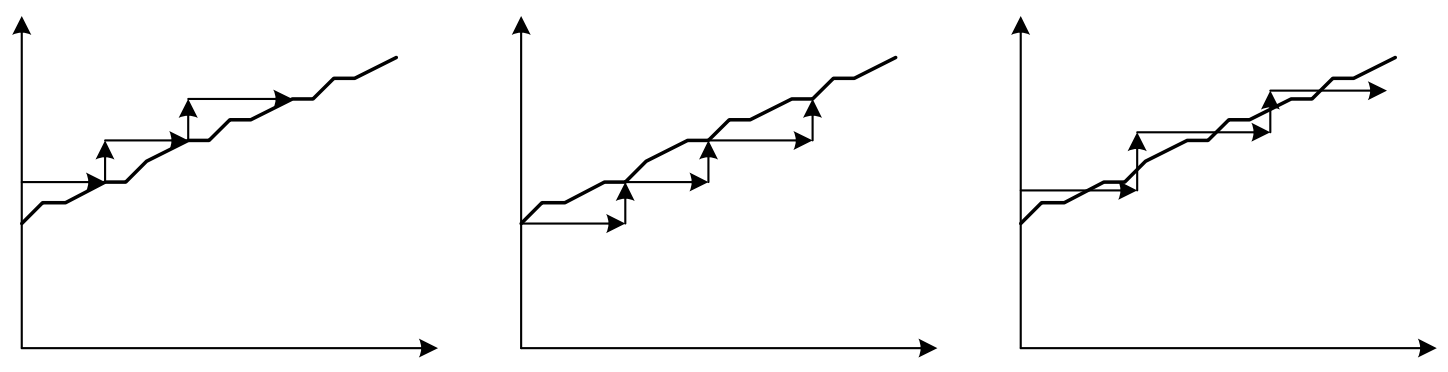

Figura 3.6 - Diferentes políticas de capacidade 
- A adição de capacidade antecipa-se às vendas previstas;

- A adição de capacidade segue-se às vendas previstas;

- A adição de capacidade procura acompanhar as vendas previstas (política mista).

Antes da escolha do melhor método de previsão, é importante compreender a natureza da demanda (dependente ou independente) e os principais componentes da previsão (o nível das vendas, os fatores sazonais, tendência de crescimento ou queda, os fatores cíclicos, as promoções e os fatores aleatórios).

Ainda, segundo Bowersox e Closs (2001), existem centenas de artigos descrevendo várias abordagens de previsão e os respectivos níveis de precisão alcançados. A complexidade e sofisticação desses métodos são cada vez maiores, devido ao uso de ferramentas avançadas de análise estatística. Porém, muitas vezes, uma técnica mais simples leva a uma boa solução, especialmente se esta depende de conhecimento especializado.

Existem três tipos de técnicas de previsão:

- As técnicas qualitativas, que se baseiam na experiência e conhecimento especializado, ideal para situações de pequena disponibilidade de dados históricos;

- Técnicas baseadas em séries temporais, que são métodos estatísticos que usam dados históricos representativos, de relação e tendências estáveis;

- Técnicas Causais, que estima as quantidades vendidas de cada produto com base em outras variáveis independentes.

\subsection{Roteirização}

A roteirizacão de veículos, dentro da Logística, procura otimizar uma função objetivo, geralmente associada a algum fator que se refira ao custo de transporte, como tempo ou distância, onde algumas restrições são aplicadas, como por exemplo, restrições de horas trabalhadas por equipes (turnos de trabalho), capacidade dos veículos ou vias, horários de entregas, entre outros. 
Como descrito anteriormente, na Tabela 3.1, a roteirização é uma operação do dia-a-dia de uma empresa (planejamento operacional) e tem grande importância na Logística, pois procura apresentar, de maneira rápida, rotas eficientes, com maior produtividade e, conseqüentemente, maior economia na operação de veículos.

Muitos métodos são aplicados na solução de problemas de roteirização e vão desde formulações matemáticas complexas, que apresentam soluções ótimas, porém de difícil solução computacional, até métodos manuais baseados na experiência particular dos operadores, que utilizam mapas gráficos para considerar a geografia, o relevo e a intuição.

Para Santos (1999), as peculiaridades de cada problema é que direcionam a sistematização deste e auxiliam na escolha de seu método de solução. Na formulação dos problemas são consideradas peculiaridades como:

- Característica da distância: euclidiana ou retangular, não orientada, orientada ou mista;

- Natureza da demanda: determinística, probabilística ou parcialmente satisfeita;

- Localização da demanda: sobre arcos ou sobre nós, e quais serão atendidos;

- Tamanho e tipo da frota disponível: um veículo, vários veículos, homogênea ou heterogênea;

- Garagem dos veículos: um depósito, vários depósitos;

- Restrições de capacidade dos veículos: capacidade igual, variada ou ilimitada;

- Tempo máximo das rotas: tempos iguais, diferentes ou não imposto;

- Tipo de atividade: coleta, entrega, mistas, "quebras" permitidas, "quebras" proibidas, volta carregada;

- Objetivos: minimizar os custos totais de roteirização, a soma total dos custos fixos e variáveis, número de veículos, maximizar o 
nível de conforto, ou uma função baseada nas prioridades dos consumidores.

A roteirização de veículos pode ser abordada de três maneiras básicas: problema de cobertura de arcos, problema de cobertura de nós e modelos gerais de roteirização de veículos.

Os dois primeiros são considerados problemas clássicos e levam em conta somente aspectos espaciais do problema.

O Problema de Cobertura de Nós ou Problema do Caixeiro Viajante é definido como a rota de distância mínima que um viajante ou veículo deve percorrer , iniciando e terminando em um mesmo ponto, de modo que todos os pontos considerados no problema sejam visitados.

O Problema de Cobertura de Arcos ou Problema do Carteiro Chinês é explicado de maneira mais detalhada a seguir, por se tratar do problema abordado por este trabalho.

A roteirização de veículos considera os dois tipos clássicos de problemas expostos anteriormente com a adição de restrições presentes em casos reais, como a restrição de capacidade de uma via ou veículo, a demanda diferenciada em cada ponto ou depósito visitado, o número total máximo de horas trabalhadas por uma equipe, o número de veículos e depósitos considerado no problema, entre outras.

\subsubsection{O Problema de Cobertura de Arcos}

Procura encontrar o percurso mínimo dentro de uma área, de maneira que todos os arcos sejam percorridos ao menos uma vez, partindo e retornando ao mesmo ponto.

Esse problema é mais conhecido na literatura como o Problema do Carteiro Chinês. Segundo Eiselt, Endreau e Laporte (1995), esse nome se deve a um matemático chinês que trabalhou como carteiro durante a revolução cultural chinesa, e que apresentou pela primeira vez a solução do problema para redes não orientadas em 1962.

Novaes (1989) comenta que o problema de cobertura de vias tem diversas aplicações na área de logística, como, por exemplo, no 
dimensionamento dos serviços de coletas domiciliar de lixo, dimensionamento de equipes de entrega postal e serviço de limpeza de ruas.

A solução do Problema do Carteiro Chinês depende da explicação de alguns conceitos básicos sobre teoria dos Grafos.

Um grafo $G(N, A)$ é um conjunto finito $N$ de nós unidos por um conjunto finito $A$ de linhas chamadas de arcos ou arestas. Se todo arco de um grafo possui sentido, as linhas que unem os nós são chamadas arcos, e ele é dito orientado (Figura 3.7). Se não houver sentido em nenhuma linha, estas são chamadas arestas e o grafo é dito não orientado (Figura 3.8). O grafo é dito misto se possuir tanto arestas como arcos (Figura 3.9).

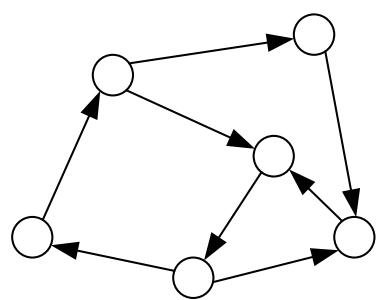

Figura 3.7 - Grafo orientado

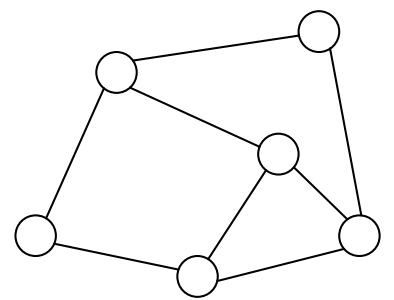

Figura 3.8 - Grafo não orientado

O grau de um nó é igual ao número de arcos que incide sobre ele. O grau de um nó pode ser ímpar se o número de arcos incidentes for ímpar e par caso contrário.

Roteiro de Euler é um circuito que atravessa todos os arcos de um grafo somente uma vez. Por ser um circuito ele necessariamente deve começar e terminar no mesmo nó.

Trilha de Euler é uma trilha que cobre todos os arcos de um grafo somente uma vez. Por ser uma trilha o nó inicial não coincide com o nó final.

Novaes (1989) explica também que a maneira clássica para resolver o problema do carteiro chinês é acrescentar arcos artificiais ao grafo original, obtendo assim um grafo $\mathrm{G}^{\prime}\left(\mathrm{N}, \mathrm{A}^{\prime}\right)$ para o qual um roteiro de Euler possa ser obtido. A adição de arcos artificiais faz com que todos os nós de grau ímpar se tornem de grau par e eles representam eventuais percursos duplos. 
Os arcos duplos são adicionados de forma que a extensão total percorrida seja mínima.

A solução do problema segue os seguintes passos:

1. Identificação dos nós de ordem ímpar;

2. Determinação das possíveis combinações de nós de grau ímpar, interligando-os com arcos artificiais, formando grafos expandidos contendo somente nós de grau par;

3. Seleção do grafo $G^{\prime}\left(N, A^{\prime}\right)$ expandido que apresenta menor extensão total;

4. Determinação do roteiro de Euler para o grafo $G^{\prime}\left(N, A^{\prime}\right)$, que é a solução otimizada do problema do carteiro chinês. A extensão total percorrida é igual à soma das extensões dos arcos de G $(\mathrm{N}, \mathrm{A})$, mais as extensões dos arcos artificiais que foram introduzidos para formar o grafo $G^{\prime}\left(N, A^{\prime}\right)$.

Para as aplicações em casos reais podem ser encontradas algumas restrições ao uso do método, como a capacidade do veículo ou o número máximo de horas trabalhadas por uma equipe. Assim, para solucionar o problema, a rede considerada, no caso prático de uma cidade, deve ser dividida em zonas que obedeçam às restrições estabelecidas (capacidade máxima do veículo, horas trabalhadas etc).

\subsection{A Logística nas cidades}

O movimento de cargas freqüentemente coloca um esforço considerável nas infra-estruturas de transporte urbanas e impõe altos custos sociais em termos de acidentes e intrusão do ambiente. Os níveis de congestionamentos nas áreas urbanas estão se intensificando como resultado do crescimento da urbanização e do uso de automóveis. As cidades estão enfrentando agora uma competição global por investimentos e o comércio, com um sistema eficiente de transporte, é necessário para a prosperidade econômica (THOMPSON E TANIGUCHI, 2001). 
Para auxiliar na operação, administração e programação dos serviços que uma cidade possui e, conseqüentemente, aumentar a eficiência do sistema de transportes urbanos, os conceitos de Logística podem ser muito úteis.

Serviços de utilidade pública, tais como coleta de lixo, assistência médica, manutenção de vias, entre outros, quando feitos de maneira eficiente e racional, permitem que mais pessoas sejam atendidas e, mais importante, beneficiando o maior número possível de pessoas.

Nisso a Logística tem um papel fundamental, uma vez que cuida para que os serviços estejam no lugar certo e no tempo certo, afetando parte significativa dos custos, seja de uma empresa pública ou de uma empresa privada.

Diversas ferramentas utilizadas na Logística podem ser usadas em auxílio aos serviços urbanos como, por exemplo, estudo de localização de instalações, útil para a localização de unidades de serviços do corpo de bombeiros e ambulâncias por exemplo, ou a roteirização de veículos para a procura de rotas eficientes para serviços de entrega de encomendas ou coleta de lixo.

No setor privado, o objetivo da Logística é o aumento dos lucros da empresa, seja reduzindo os custos, seja aumentando suas vendas, procurando, assim, atender aos clientes com um nível de serviço estipulados por seus planejadores.

Já para o setor público, o planejamento logístico não tem como preocupação aumentar os lucros, que sempre estará por volta de zero, mas com o aumento dos benefícios à população (seus "clientes"), através do aumento da eficiência dos serviços públicos, atende assim ao maior número possível de pessoas, maximizando o nível de serviço para a quantidade de recurso aplicado.

Portanto, os conceitos sobre aumento de receita através do aumento do nível de serviço, como ilustrados nas Figura 3.1 e 3.2 não se aplicam aos serviços públicos, pois esses, como dito anteriormente, não visam o lucro e suas receitas provêm de orçamentos fixos, previamente estipulados pelos administradores públicos. Sendo assim, um aumento no nível de serviço não 
geraria aumento de receita, mas sim um aumento na qualidade do serviço e um número maior de pessoas atendidas utilizando a mesma estrutura.

Melo (1998) compara o pavimento a uma empresa e diz que o seu sucesso está relacionado com o correto atendimento das necessidades, expectativas e desejos de seus clientes, através da prestação de serviços, oferecendo um tráfego de veículos confortável e seguro do ponto de vista do usuário.

Haas \& Hudson (1996) relacionam a satisfação dos usuários de pavimentos com algumas características ou medidas físicas, algumas delas relacionadas aos serviços de manutenção das vias:

- Qualidade de viagem;

- Defeitos na superfície do pavimento;

- Atrito da superfície do pavimento;

- Drenagem superficial;

- Ruídos;

- Perdas de tempo, geradas pelas atividades de manutenção e reabilitação de pavimentos e outros;

- Custos e benefícios em dispêndios e ações para minimizar os custos de transporte, reduzir a emissão de poluentes e perda de tempo em manutenção e reabilitação etc.

Assim, as ferramentas e conceitos da Logística de Serviços, como mostrados anteriormente, podem ser utilizados no auxílio dos serviços públicos, incluindo o serviço de remendos em pavimentos urbanos, aumentando sua eficiência, maximizando os recursos investidos, preservando os pavimentos urbanos e, conseqüentemente, trazendo maiores benefícios à população. 


\section{O SISTEMA DE INFORMAÇÕES GEOGRÁFICAS}

Os Sistemas de Informações Geográficas, ou SIGs, descritos e utilizados em muitos trabalhos são, segundo Sarkis (2000), uma coleção de hardware, software, dados geográficos e pessoal, projetados para eficientemente capturar, armazenar, atualizar, manipular, analisar e apresentar todas as formas de informações referenciadas geograficamente.

Exstem inúmeros trabalhso que trazem maiores detalhes sobre os componentes e características dos SIGs. Por isso, este capítulo estará focado em mostrar a importância do uso do SIG no planejamento urbano e como algumas de suas características podem ser úteis nessa tarefa.

\subsection{A importância do uso do SIG no planejamento urbano}

Diversos trabalhos apresentados nos últimos anos relatam o uso do Sistema de Informações Geográficas (SIG) como ferramenta importante, senão fundamental no planejamento de transportes e urbano.

Os SIGs não são um mero auxílio à produção de desenhos. Trata-se de uma tecnologia que oferece ferramental operacional que auxilia e agiliza procedimentos de planejamento, gerência e de tomada de decisão, sendo utilizada de forma promissora nas mais diferentes áreas (PANTIGOSO e FERNANDES Jr., 1997).

Tais afirmações se devem à característica dos SIGs, de juntar mapas digitalizados, extraídos de locais reais, às informações armazenadas em banco de dados, permitindo simulações de situações específicas no ambiente estudado. 
Naruo (2003) cita o SIG como um instrumento capaz de auxiliar na tomada de decisões no nível de planejamento estratégico, pois possibilita a geração de informações instantâneas, para a elaboração e escolha de alternativas.

A Tecnologia SIG pode ser vista como resultado da junção de dois programas consagrados, o DBMS (data base management system) e o CAD (computer-aided design), com adição de ferramentas especializadas para gerência e análise de dados espaciais (ZANCHETTA 2005).

Porém, alguns autores, como Naruo (2003) e Silva (1998), destacam que um SIG não se refere apenas aos componentes de software e hardware. É necessário também o componente humano: o profissional treinado e capacitado a operar o sistema.

A característica de junção de dados espaciais com um banco de dados e o uso de programas que operam esses dados é que torna o SIG tão útil ao planejamento urbano ou ao planejamento dos transportes, pois o conjunto de programas existentes em um SIG permite, por exemplo:

- Localização de uma entidade e/ou listagem de seus atributos;

- Atualização de dados;

- Cálculo de áreas, perímetros;

- Estabelecimento de distâncias como, por exemplo, a menor distância entre dois pontos, rota mais curta ou mais rápida;

- Traçado de redes;

- Operações aritméticas e lógicas entre planos de informações;

- Cálculos estatísticos;

- Reagrupamento de dados;

- Cruzamento dos planos.

Silva (1998) comenta que o uso do SIG possibilita um melhor aparelhamento profissional no planejamento do país, poupando tempo e garantindo análises mais confiáveis. 
Ainda segundo Silva (1998), o uso do SIG não assegura, por si só, uma análise de melhor qualidade, mas permite o acompanhamento gradual dos passos dessas análises, através de recursos gráficos que facilitam bastante a compreensão, ajudando a manter a correção contínua dos processos.

Para Bertollo (1997), a indispensável integração dos sistemas de gerência da infra-estrutura urbana, facilitada com o uso do SIG, diminuiria o problema causado por concessionárias de água e esgoto das cidades, responsáveis por grande parte dos remendos nos pavimentos urbanos gerados pelos serviços de manutenção ou instalação de redes subterrâneas.

Zhang et al. ${ }^{3}$ (1994 apud Pantigoso \& Fernandes Jr. 1997) também discutem a necessidade de um sistema de gerência global e abrangente, de tal forma que todos os sistemas de infra-estruturas (pavimentos, água, esgoto, energia elétrica etc.) possam ser integrados em uma plataforma comum, buscando melhorar as decisões de gerência (Figura 4.1).

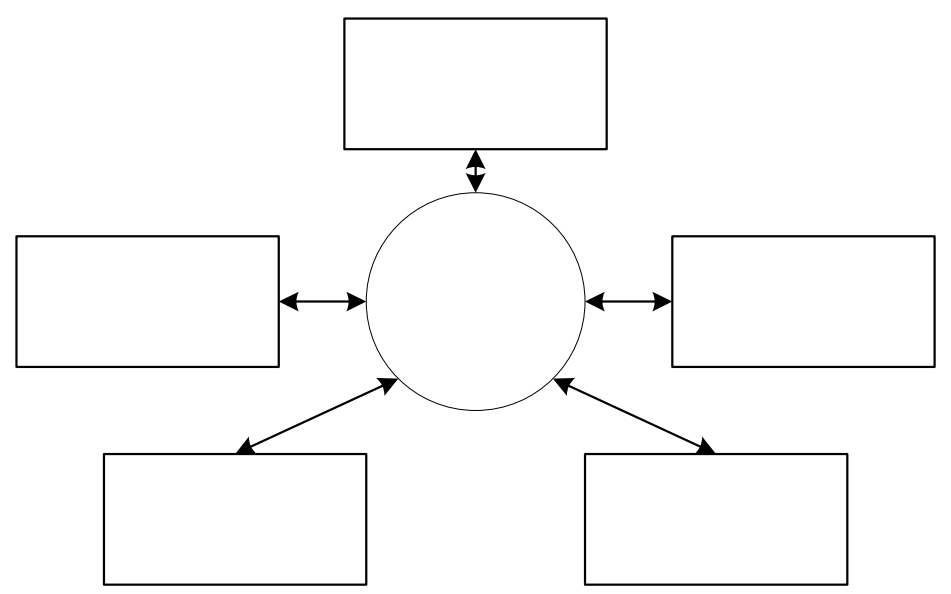

Figura 4.1 - Conceito de sistema de gerência global da infra-estrutura urbana (adaptada de ZANG et al., 1994)

Fonte: Pantigoso (1997)

\footnotetext{
${ }^{3}$ ZHANG, Z. et al. (1994). Gis Integrated Pavement and Infraestructur Management in Urban Areas. Transportation Research Record 1429. TRB. NationalResearch Council. Washington, D.C.p.84-89 apud PANTIGOSO, J.F.G., FERNANDES Jr., J.L. (1997). Compatibilização da gerência de pavimentos urbanos com as concessionárias de serviços públicos com o uso de SIG in XI CONGRESSO DE PESQUISA E ENSINO EM TRANSPORTES - ANPET. 1a edição, Universidade Federal do Rio de Janeiro, Rio de Janeiro, p. $67-70$
} 
As características do SIG de apresentar sua base de dados em diversas camadas diferentes (layers), como exemplificado na Figura 4.2, além da sua capacidade de cruzar informações, de manejar esses dados e de apresentar a visualização gráfica das informações, permitem a integração dessas operações e a compatibilização dos sistemas de gerência da infra-estrutura urbana na medida em que estabelecem uma base comum de dados geograficamente distribuídos.

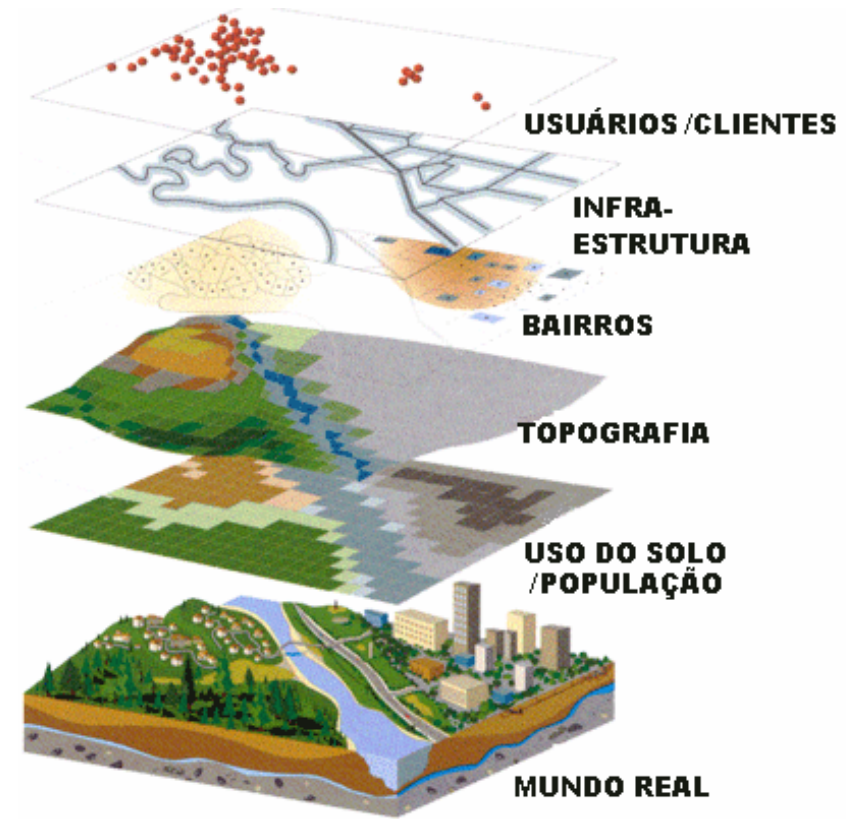

Figura 4.2 - Representação geográfica em camadas de um SIG

Os SIGs possuem pacotes de programas, ou rotinas, muitas delas com aplicação para as áreas de transportes, logística e pesquisa operacional, que permitem determinar o caminho de custo mínimo entre dois pontos, distribuir viagens entre zonas, resolver problemas de roteirização e programação de veículos, localização de instalações, alocação de tráfego, entre outras tarefas.

Santos (1999) discorre sobre a aplicação do SIG nos transportes, nos três níveis de planejamento: estratégico, tático e operacional. Em nível operacional, o SIG se aplica na roteirização e questões do dia-a-dia dos transportes urbano e rodoviário de cargas, engenharia de tráfego e transporte coletivo urbano. No planejamento tático, os projetos estão centralizados no transporte coletivo, definição de zonas de análise de tráfego, transporte rodoviário e urbano de carga. Análises sobre clientes em potencial, a imagem do setor junto aos clientes e aumento de receita estão a cargo do planejamento estratégico. 
Para Pelizaro (2000), o uso do SIG é muito conveniente quando os clientes variam muito e os locais de coleta e/ou entrega estão em constante mudança no sistema de distribuição.

Esta característica de constante mudança de clientes e locais de entrega não se aplica somente aos sistemas de entregas de lojas de departamentos. Ela também se aplica ao objeto de estudo deste trabalho, no caso o problema de roteirização de equipes que efetuam o serviço de remendos de pavimentos urbanos, como poderá ser mais bem observado nos capítulos seguintes.

O uso do SIG nas tarefas de roteirização de equipes de entrega ou coleta de mercadorias e produtos se mostra bastante interessante do ponto de vista prático, uma vez que as rotas geradas pelos softwares, apresentadas em diversos trabalhos, são muito superiores às rotas elaboradas manualmente.

Portanto, o uso do SIG proporciona aos clientes e empresas vantagens econômicas, pois o programa consegue gerar novas rotas de maneira rápida e com economia de quilometragem percorrida ou tempo gasto na tarefa, o que gera uma diminuição de tempo trabalhado e mão-de-obra utilizada para executar a entrega.

\subsection{O TransCAD}

O software TransCAD é um SIG destinado a ajudar os profissionais e empresas da área de transportes em seus trabalhos diários e a gerenciar e obter informações estratégicas sobre seus negócios.

Silva (2005) descreve o TransCAD como um software de interface bastante amigável, tanto para o usuário, principalmente durante a modelagem, quanto para aqueles que apenas farão uso dos resultados gerados, por meio de mapas temáticos e tabelas extraídas dos bancos de dados.

Além das funções básicas de um SIG, o TransCAD possui rotinas específicas para soluções de problemas de logística, pesquisa operacional e transporte em geral.

Segundo Pelizaro (2000), o software possui um conjunto de ferramentas bastante robusto, indicando a habilidade da heurística utilizada de executar 
bem uma grande variedade de problemas, tornando-o capaz de resolver vários tipos de problemas de roteirização de veículos.

O TransCAD foi usado em diversos trabalhos acadêmicos simulando situações reais, em que se procurava otimizar rotas, localização de instalações ou visualizar dados espaciais.

O trabalho de Zanchetta (2005) e Lima et al. (2004) utilizaram o TransCAD no Sistema de Gerência de Pavimentos Urbanos (SGPU) para a cidade de São Carlos, pois a combinação de uma base de dados com mapas digitalizados possibilita uma visualização de vários dados isolados ou agrupados.

O trabalho de Deluqui (1998) utiliza a cobertura em arco (Problema do Carteiro Chinês) para a roteirização de veículos de coleta de resíduos sólidos domiciliares.

Santos (1999) o utiliza para roteirizar veículos de entrega de bebidas, além de utilizar a rotina de agrupamento do software para definir quais pontos de entrega devem ser atendidos por uma determinada rota.

Sarkis (2000) propõe o uso da roteirização, através do Problema do Caixeiro Viajante (PCV), na coleta de resíduos do Serviço de Saúde. Porém, chega à conclusão que o software não se adapta às reais condições de coleta desses resíduos.

Naruo (2003) utilizou o TransCAD em um estudo logístico, em nível estratégico, para determinar a melhor localização de um aterro sanitário para disposição de resíduos sólidos, por meio do uso consorciado de diversos municípios da região de São Carlos. Nesse estudo foram utilizadas as rotinas de localização de instalações, roteirização e programação de frota.

Silva (2005) utiliza a rotina de caminho mínimo em seu trabalho sobre a distribuição modal rodo-ferroviária, para a exportação de açúcar a granel através do Porto de Santos, e explica o princípio de funcionamento dos solvers para os Problemas do Transporte e do Caminho Mínimo.

Esses são apenas alguns exemplos de aplicação de um SIG, no caso o TransCAD, para situações reais e para diferentes tipos de serviços. 


\section{MÉTODO}

O método aplicado nesta dissertação pode ser dividido em três etapas (Figura 5.1): dados, aplicação desses dados no programa TransCAD e elaboração de uma relação entre os remendos executados com a pluviosidade de cada período.

Primeiro foram coletados os dados de campo junto à prefeitura de São Carlos e às empresas que participam do serviço de remendos nos pavimentos da cidade

A segunda etapa foi a inserção dos dados coletados sobre as vias da cidade e do serviço estudado (roteiros, quantidades, tempos etc.) no TransCAD e a simulação de diferentes rotas com o uso do roteirizador do programa.

A terceira etapa consistiu na observação dos índices pluviométricos de São Carlos durante um certo período e da quantidade de serviços executados nesse mesmo período, a fim de estabelecer, se possível, uma relação que permita uma previsão da quantidade de remendos necessários de acordo com a pluviosidade e, conseqüentemente, em cada época do ano.
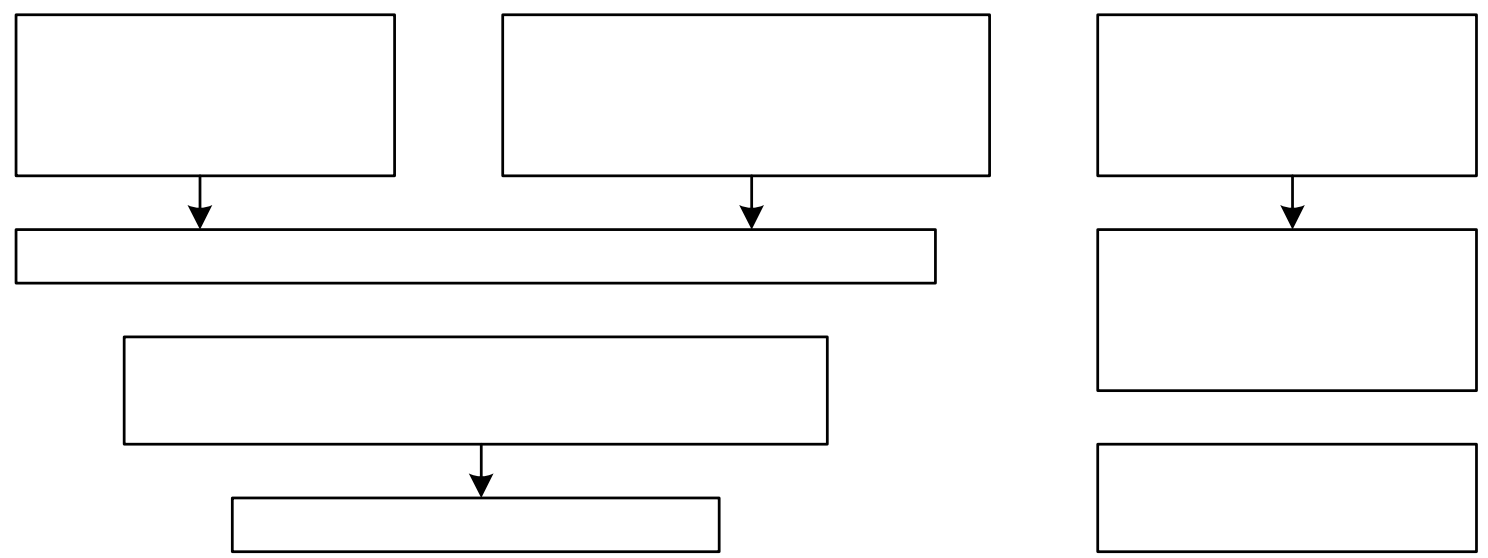

Figura 5.1 - Esquema das etapas do Método

\subsection{Primeira etapa: Coleta de dados}


A primeira etapa do método consistiu de uma coleta de dados junto à Prefeitura sobre as instalações utilizadas, os serviços executados pela própria Prefeitura, contratos de serviços de terceiros e o cadastro das ruas da cidade.

Também foi acompanhado o trabalho das equipes contratadas pela Prefeitura, pois essas executavam a maior parte do serviço de remendos na cidade, visando a observação das características do serviço.

\subsubsection{Coleta de dados junto a Prefeitura}

As informações sobre as vias da cidade foram coletadas na Divisão de Trânsito da Prefeitura Municipal de São Carlos, que forneceu um arquivo eletrônico, em formato dwg (AutoCAD), contendo as ruas da cidade de São Carlos.

Esse arquivo foi plotado e nele foram anotadas as informações sobre o sentido de cada via da cidade, assim como pequenas alterações e atualizações (novas ruas, por exemplo). Essas informações foram utilizadas na segunda etapa do método.

Os dados sobre o serviço de remendos foram coletados primeiramente junto à Divisão de Vias Públicas da Secretaria de Obras da Prefeitura Municipal de São Carlos.

A Divisão de Vias Públicas informou que uma pequena parte do serviço de remendos era executado pela Prefeitura e a maior parte por empresas contratadas.

Sobre o serviço executado pela prefeitura foram coletados dados sobre o número de funcionários, equipamentos, materiais (Concreto Betuminoso Usinado a Quente - CBUQ ou Pré Misturado a Frio - PMF) e roteiros utilizados.

Foram obtidas também informações sobre o ciclo de um pedido pelo serviço de remendos na prefeitura: como são feitos; como é a aquisição de materiais, serviços e insumos; como os pedidos são ordenados, executados e fiscalizados.

Esses dados são importantes para se compreender como é o ciclo de um pedido na prefeitura de São Carlos e como ele afeta o método proposto, ou ainda, como algumas mudanças poderiam aumentar a eficiência do serviço. 
Parte das informações sobre o serviço contratado também foi coletada nessa fase. A Divisão de Vias Públicas informou detalhes do contrato como: duração, quantidade, fornecimento de materiais, memorial descritivo do serviço e as obrigações da contratada e do contratante.

Além das informações anteriormente citadas, foi fornecido também o histórico do serviço de remendos, referente ao último contrato da prefeitura (de janeiro de 2004 até janeiro de 2006).

\subsubsection{Acompanhamento das equipes que executam remendos nos pavimentos de São Carlos}

Houve um acompanhamento, por quatro dias das, equipes que executam os serviços de remendos em pavimentos em São Carlos, onde foram observados:

\section{- Equipes e equipamentos}

Número de funcionários e o tipo de equipamentos efetivamente empregados para execução dos remendos nos pavimentos.

- Procedimentos

As operações necessárias para a execução dos remendos: sinalização, preparo da área, lançamento da massa asfáltica, compactação etc.

\section{- Roteiros}

Como são definidos os roteiros de serviço de cada dia de trabalho, a partir das informações sobre a localização das panelas e o tipo de material empregado (PMF ou CBUQ).

\section{- Rendimento das equipes}

Foi observado o rendimento de cada equipe, ou seja, quantos metros quadrados de remendo, por tipo de material aplicado, as equipes conseguem executar em um dia de trabalho.

A observação se fez com a distribuição de planilhas aos motoristas de cada equipe (Figura 5.2), onde era anotado o nome do encarregado da equipe, o tipo de material aplicado, a hora da saída e da chegada de cada equipe na 
garagem, a quilometragem do caminhão na saída e na chegada da garagem, e a hora da chegada e da saída de cada equipe na usina.

\begin{tabular}{|c|c|}
\hline Encarregado & Dia \\
\hline Saída garagem (hora) & Quilometrgem chegada \\
\hline Quilometragem saída & \begin{tabular}{|l} 
Chegada garagem (hora) \\
\end{tabular} \\
\hline $\begin{array}{l}\text { USINA PRIMEIRA } \\
\text { VEZ: }\end{array}$ & $\begin{array}{l}\text { USINA } \\
\text { SEGUNDA VEZ : }\end{array}$ \\
\hline Onde (USINA) & Onde (USINA) \\
\hline Chegada Usina (hora) & Chegada Usina (hora) \\
\hline Quantidade & Quantidade \\
\hline Saída Usina (hora) & Saída Usina (hora) \\
\hline
\end{tabular}

Figura 5.2 - Planilha entregue aos motoristas

- Apresentação do serviço executado à Prefeitura

A empresa contratada deve apresentar à Prefeitura, todo mês, uma planilha contendo informações sobre a localização e o tamanho de cada remendo executado.

Para isso, cada equipe faz um croqui, que é entregue ao fim do dia na empresa, contendo o nome da rua, a localização da panela (geralmente o número da primeira casa em frente à panela) e o tamanho do remendo executado.

Esse croqui foi copiado ao fim de cada dia de trabalho, sendo recolhida também, junto aos motoristas, a planilha indicada na Figura 5.2. Assim, foi possível determinar a rota, os tempos e a quantidade de remendos executados por cada equipe.

Porém, a quilometragem total percorrida por cada equipe teve de ser estimada usando o TransCAD e o roteiro apresentado a cada dia, pois nem todos os hodômetros dos caminhões funcionavam.

Para tal estimativa foi usado o comando Network/Paths-Shortest Path, que apresenta o caminho mínimo entre os pontos de serviço escolhidos. 
Caminho mínimo são rotas sobre redes de transportes que possuem o custo generalizado mínimo, onde o custo pode ser uma combinação de fatores tais como distância, tempo ou o valor monetário da viagem (CALIPER, 1999).

Portanto, a quilometragem total percorrida a cada dia de serviço é a soma do caminho entre a usina da prefeitura até o primeiro ponto de serviço da equipe (primeiro remendo do croqui), mais o caminho mínimo entre todos os pontos de serviço, mais a quilometragem para o retorno à usina, a volta para continuação do serviço (quando necessário), e mais a quilometragem entre o último ponto de serviço do dia e a garagem.

\subsection{Segunda etapa: Aplicação da ferramenta de roteirização do TransCAD}

O TransCAD 3.6 foi a ferramenta escolhida para compor as rotas a partir dos dados coletados, pela facilidade de sua utilização. Porém, o programa apresentou alguns inconvenientes durante sua utilização, como será exposto nas seções seguintes deste capítulo.

Primeiro foram inseridos os dados de entrada no TransCAD: camada de linhas (vias) e pontos (panelas). Em seguida, foi usado o procedimento de roteirização em arcos.

\subsubsection{Dados de entrada}

A base geográfica utilizada neste trabalho foi adquirida de um projeto anterior (feito com o auxílio de uma mesa digitalizadora e do programa TransCAD). Portanto, o início deste trabalho parte das informações referentes a alguns links como: número identificador, comprimento e nome do logradouro.

Porém, ao longo dos anos, a cidade de São Carlos passou por várias modificações em seu sistema viário, como a construção de novas ruas e a mudança do sentido da maioria das ruas. Assim, se fez necessária a atualização da base de dados existente.

Para isso, foram utilizados os softwares Transcad 3.6 e Arcview, o arquivo dwg contendo o mapa atualizado da cidade e informações sobre o sentido de cada rua da cidade.

O arquivo dwg foi importado para o TransCAD com o auxílio do Arcview e inserido como uma nova camada. Com o uso de ferramentas de edição do 
TransCAD e a nova camada, foram então adicionados os novos links (novas ruas) que faltavam.

A nomeação desses novos links e a definição dos sentidos de todas as ruas foram feitas manualmente, um a um.

Toda a etapa de atualização da base de dados se mostrou muito trabalhosa e foi dividida entre outras pessoas que utilizariam a base de dados de São Carlos em suas pesquisas acadêmicas.

O SAAE (Serviço Autônomo de Água e Esgoto) de São Carlos cedeu o arquivo de base de dados geográfico, contendo a numeração das casas da cidade. Isso ajudou na localização dos remendos executados, pois no croqui apresentado pelas equipes, além do nome da rua, era marcado também o número da casa em frente à qual foi executado o remendo.

Geralmente, em frente a uma casa são executados mais de um remendo. Assim, as quantidades desses remendos são somadas, e a quantidade total é adicionada à camada de links, como é exemplificado na Figura 5.3.

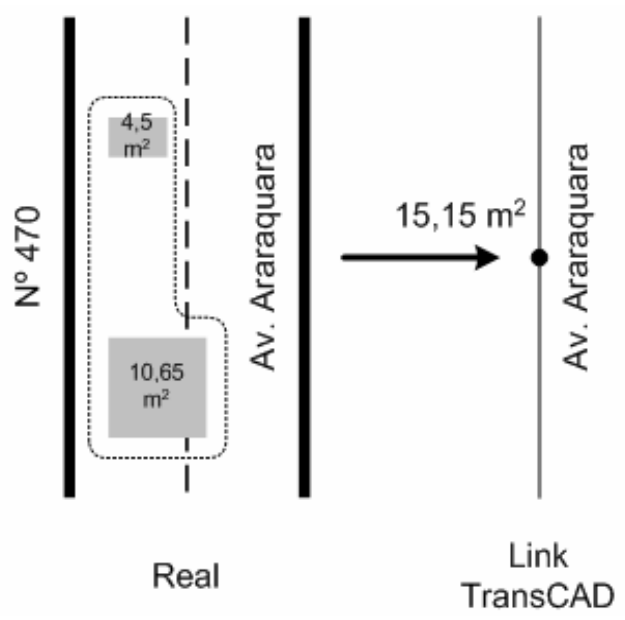

Figura 5.3 - Passagem de dados do croqui para os links no TransCAD

A Figura 5.4 mostra o mapa de São Carlos, com a localização desses remendos. Para a elaboração desse mapa foi criado um arquivo geográfico de pontos e, com o uso do comando Tools-Map Editing, foram marcadas todas as panelas remendadas no período. Com o comando Dataview-Modify Table foram lançados os dados como: nome das ruas, número da casa e tamanho do remendo executado. 


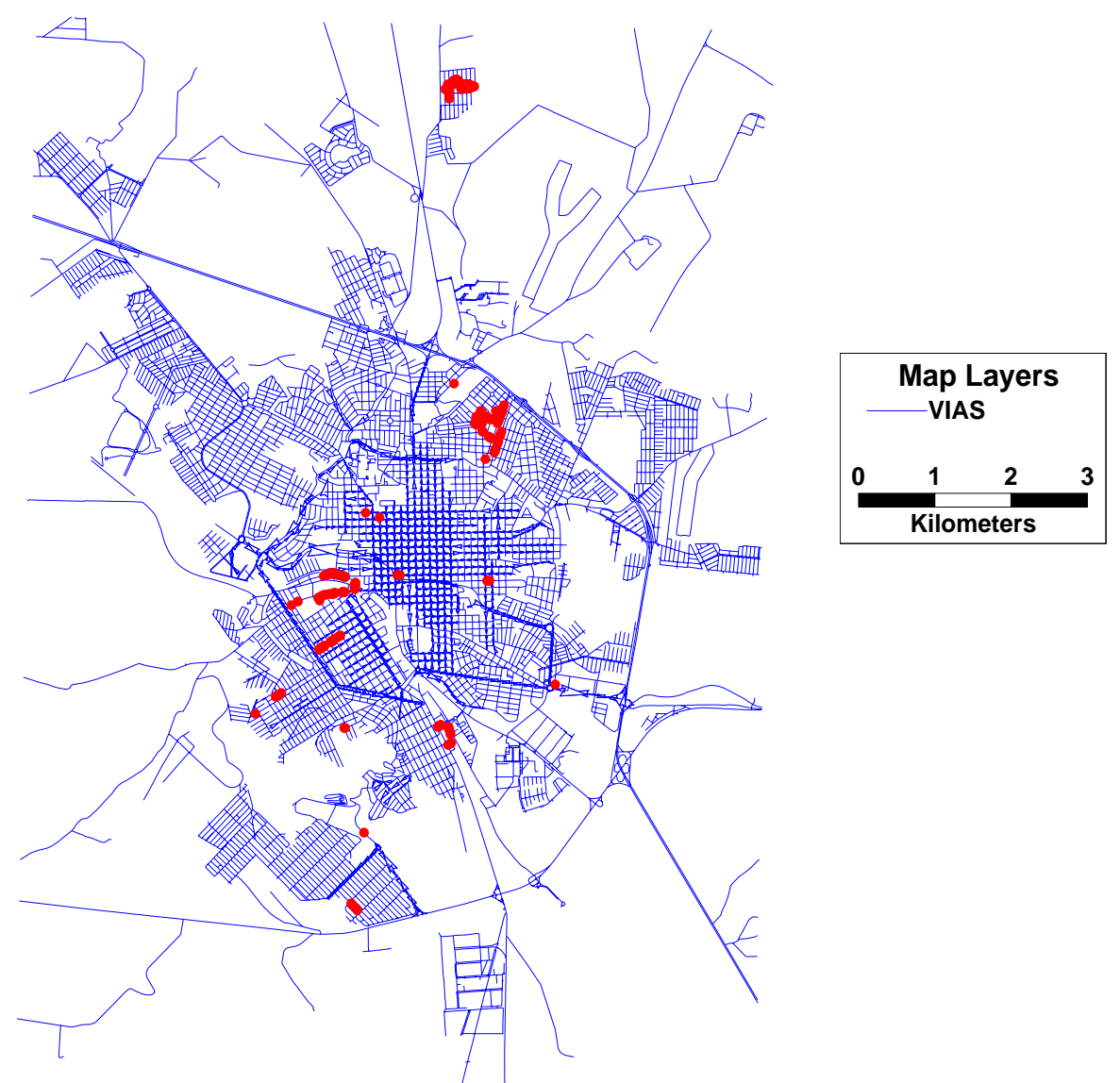

Figura 5.4 - Distribuição espacial das panelas em São Carlos durante o período de estudo

A camada de panelas foi necessária para a etapa de separação dos links onde foram executados os remendos no pavimento. Os links das ruas foram separados nos pontos onde se encontravam as panelas, usando-se o comando Tools-Map-Editing-Split Line na camada de ruas da base de dados, como mostra a Figura 5.5. A quantidade de remendos em cada link foi adicionada também à camada de linhas com a criação da coluna SERVICE LOAD (m2).

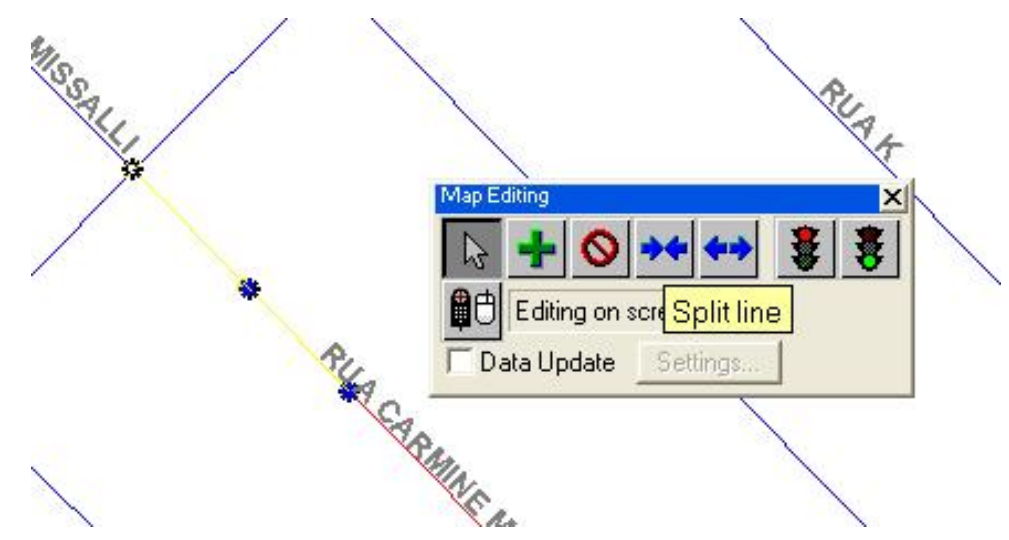

Figura 5.5 - Separação dos links das ruas nos locais das panelas 
Outra coluna necessária foi a de VELOCIDADE nos links. Assim, foram consideradas diferentes velocidades para os links, dependendo de sua capacidade.

Nas rodovias de grande fluxo de veículos (Washington Luiz), foi estimada a velocidade de $70 \mathrm{~km} / \mathrm{h}$, nas demais rodovias e estradas municipais foi estimada a velocidade de $60 \mathrm{~km} / \mathrm{h}$. Nas ruas e avenidas da cidade a velocidade estimada foi de $30 \mathrm{~km} / \mathrm{h}$. Todas as estimativas foram feitas considerando-se velocidades inferiores às velocidades máximas permitidas em cada tipo de via

Para os links onde o serviço de remendos foi executado, a velocidade de operação considerada foi de $0,09 \mathrm{~km} / \mathrm{h}$. O cálculo dessa velocidade é feito utilizando-se as equações eq.(1), eq.(2) e eq.(3) e os dados coletados sobre o serviço de remendos.

$$
V O=\frac{k m R O T_{t}}{T_{t} \text { Operação }}
$$

Onde:

$V O=$ Velocidade de Operação

$\mathrm{kmROT}_{t}=$ Quilometragem de Roteiro

O Tempo Total de Operação ( $T_{t}$ Operação) é o tempo estimado somente para executar os remendos.

$$
T_{t} \text { Operação }=T_{t} \text { Trab }-T_{F O}
$$

Onde:

$T_{t}$ Trab $=$ Tempo Total de Trabalho

$T_{F O}=$ Tempo Fora de Operação

O Tempo Fora de Operação ( $T_{\mathrm{FO}}$ ) é o tempo em que o veículo está em direção ao local do serviço ou em direção à usina ou, é o tempo que o veículo leva para chegar até a garagem ao final dos serviços.

$O T_{F O}$ foi obtido da seguinte forma:

$$
T_{F O}=\frac{k m_{t}-k m R O T_{t}}{30,00}
$$

Onde:

$$
k m_{t}=\text { Quilometragem Total Percorrida }
$$


Na Figura 5.6, a coluna de VELOCIDADE foi usada para o cálculo da coluna TIME, que é o tempo necessário para se percorrer cada ligação.

\subsubsection{Roteirização em arco}

Para o uso da roteirização em arco é necessário preparar a camada de linhas com alguns dados adicionais, como o campo COST (Deadhead Cost), que é o custo para se atravessar a ligação sem oferecer o serviço. O TransCAD procura minimizar esse custo na roteirização em arco, respeitando a quantidade de horas trabalhadas por dia ou a carga total do veículo considerada. Para os links que continham serviço foi considerada a velocidade de $30,00 \mathrm{~km} / \mathrm{h}$.

O campo TIME foi então preenchido com o tempo em minutos para atravessar cada link, considerando a execução dos serviços onde necessário. Para isso, a coluna de comprimento do link (Length) foi dividida pela coluna de VELOCIDADE. Nos links onde existia o serviço, a velocidade considerada foi de $0,09 \mathrm{~km} / \mathrm{h}$, para os links onde não existia serviço foi considerada a velocidadede $30 \mathrm{~km} / \mathrm{h}$ para vias urbanas, $70 \mathrm{~km} / \mathrm{h}$ para rodovias e $60 \mathrm{~km} / \mathrm{h}$ para estradas municipais.

Outros campos necessários são: SERVICE FLAG, que aloca a ligação a um território, $A B$ SERVICE e BA SERVICE, que indicam o lado da rua onde 0 serviço é necessário. A Figura 5.6 mostra a tabela de links completa para a roteirização em arco.

As colunas $A B$ SERVICE e BA SERVICE também indicam a que região pertence o link.

Os locais onde foram executados os serviços de remendos em pavimentos durante os dias da coleta de dados foram separados em 6 territórios onde os remendos eram mais próximos uns dos outros, como mostra a Figura 5.7.

Na camada de nós, foi selecionado o nó correspondente à usina. Foi criada uma rede com todos os links, contendo os campos com seus comprimentos, tempos, custos, SERVICE LOAD e SERVICE FLAG. 


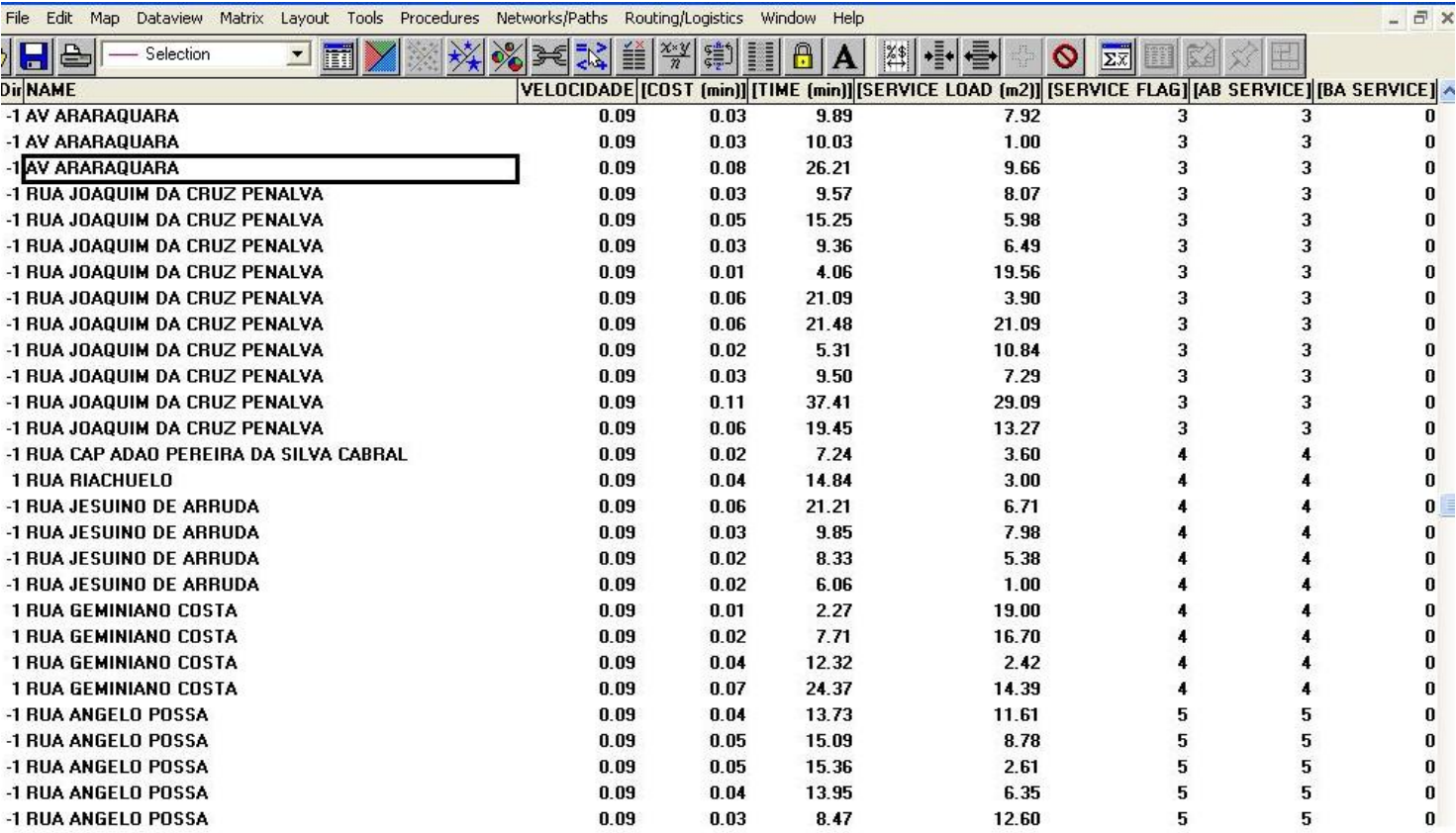

Figura 5.6 - Tabela da camada de links (ruas)

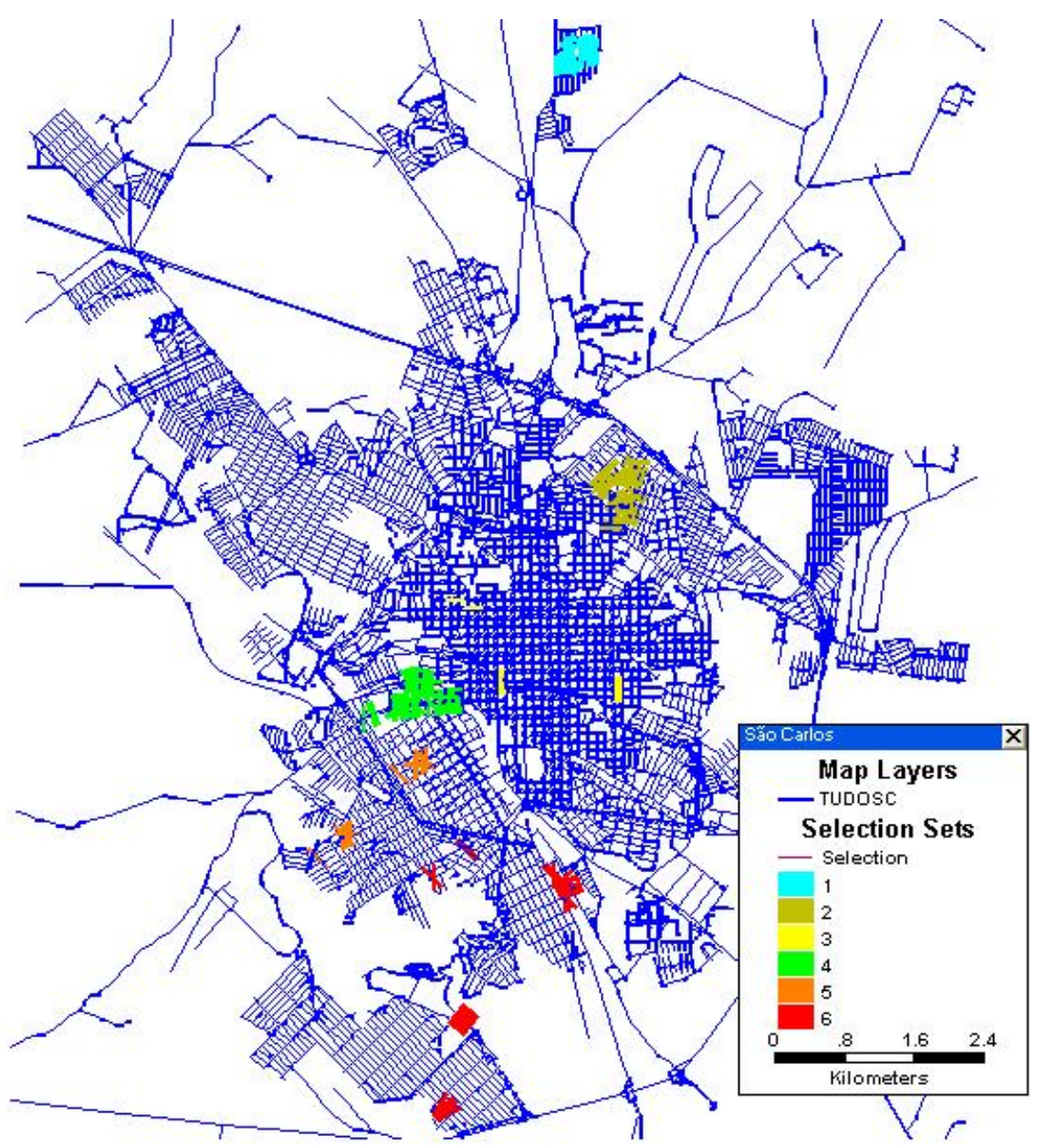

Figura 5.7 - Territórios dos links que contém serviços 
Usando o comando Routing/Logistics-Arc/Street - Routing-Arc Routing foram criadas as rotas dos seis territórios selecionados, uma por vez, alterando-se o número na caixa Service Code, como indicado na Figura 5.8.

Foram criados turnos de trabalho (shifts), considerando-se que a quantidade máxima de serviço para cada um desses turnos seria a execução de $240,04 \mathrm{~m}^{2}$ de remendo.

Esse limite de remendos para cada turno é igual a média observada durante o período de coleta de dados para um dia de serviço, considerando a utilização de caminhões com capacidade para $5 \mathrm{~m}^{3}$ de carga, tipo mais utilizado no período observado.

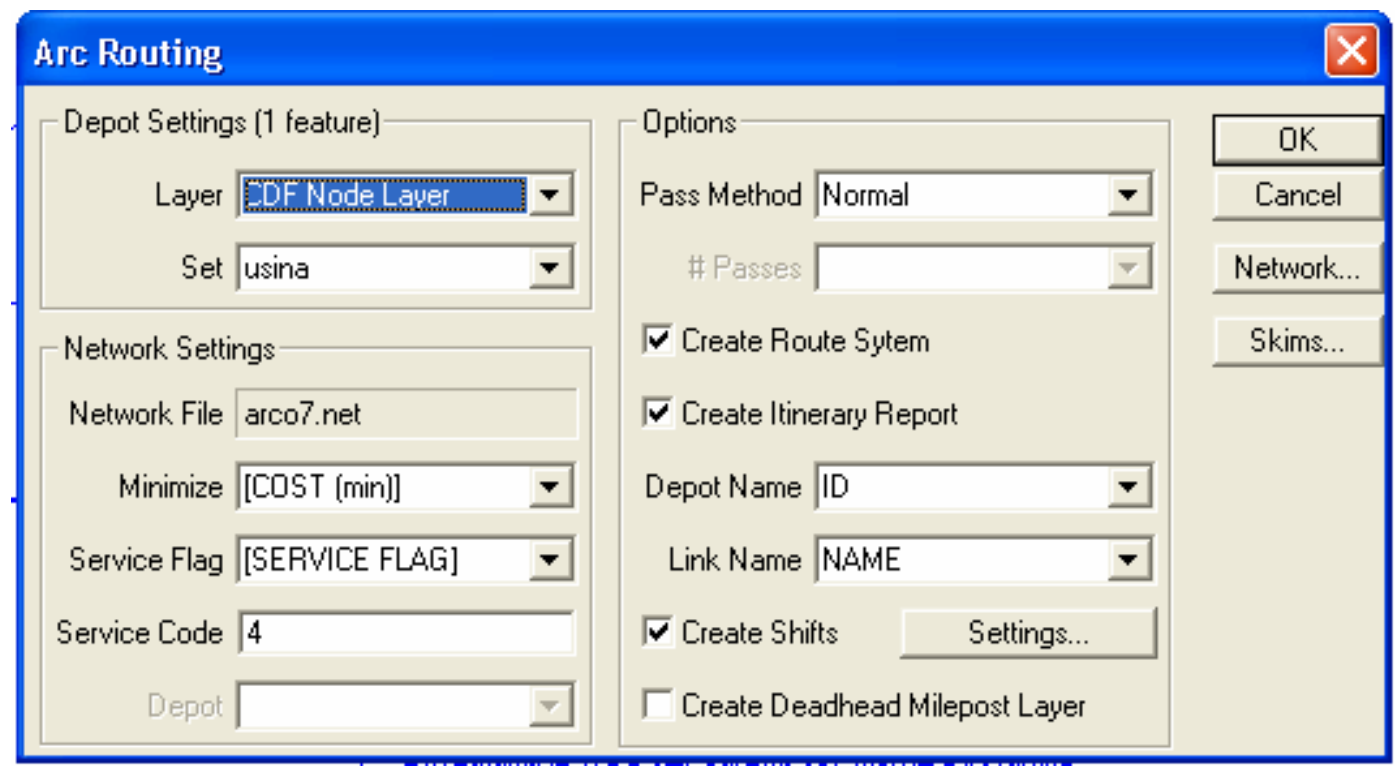

Figura 5.8 - Janela Arc Routing do TransCAD

O procedimento de roteirização em arco apresentou alguns problemas. Quando a rota passava em links que necessitavam de serviço e tinham duas mãos de direção, o programa apresentava uma rota que passava duas vezes por esse link e a quantidade de serviço era contada duas vezes. Isso resultava num número de turnos maior que o necessário e contagem duplicada da quilometragem desses links.

Esse problema foi sanado colocando-se sentido nos links onde o serviço era necessário. Com esse procedimento, a rota criada passava somente uma vez por esses links e o serviço era contabilizado corretamente. 
O TransCAD fornece um arquivo com o itinerário e a carga de quantidade de serviço de turno de trabalho (ANEXO A) e um arquivo com o mapa da rota para cada território.

Esses resultados foram agrupados em dias, considerando-se que: cada equipe trabalha cerca de nove horas por dia, que a empresa possui caminhões de $5 \mathrm{~m}^{3}$, que em apenas 1 dia foi usado o caminhão de $10 \mathrm{~m}^{3} \mathrm{com}$ capacidade máxima de 480,08 $\mathrm{m}^{2}$ (mesmas condições das equipes durante a coleta de dados), e que os turnos que apresentaram quantidade de serviço muito baixa foram somados aos turnos com quantidade baixa do território mais próximo.

Outro problema apresentado pelo TransCAD é que as rotas geradas não consideram a necessidade de recarga do veículo ou a possibilidade dele iniciar a jornada de serviço em um depósito e terminar em outro.

Tal defeito também foi detectado em outros trabalhos, como o de Deluqui (1998), que comenta que o TransCAD considera que o veículo coletor sai de um ponto (garagem), percorre o setor de coleta e volta ao nó de origem (garagem).

Essa deficiência do programa não permite a análise do problema como ele ocorre na realidade, pois freqüentemente o caminhão volta à usina para recarregar e continuar o serviço. Acontece, também, que ao final do dia o caminhão se dirige à garagem da empresa e não à usina, como foi considerado na simulação.

Então, para solucionar esses problemas, foi usado o comando Shortest path para considerar a quilometragem e o tempo gasto para voltar e recarregar o caminhão, ou para retornar até a garagem ao fim de cada dia de serviço.

\subsection{Terceira etapa: Previsão de remendos de acordo com a pluviosidade}

Como foi explicado anteriormente, as panelas aparecem em função do tráfego, da idade do pavimento e da presença de água no pavimento, o que quer dizer que no período das chuvas aparecem mais panelas nos pavimentos.

Assim, a previsão de demanda, ou seja, a quantidade de serviços de remendos a ser contratada e a melhor maneira de alocar no tempo esses recursos depende de informações históricas sobre a pluviosidade, a quantidade 
de panelas que surgem de acordo com o tipo de via em que aparecem (arterial, coletora ou local) e a idade de tais vias.

Porém, os dados existentes para análise são somente a quantidade de remendos executada por medição e a pluviosidade de cada mês.

Os dados cedidos pela Prefeitura sobre os totais de remendos executados a cada medição no ano de 2004 foram separados por mês.

As informações sobre a pluviosidade de cada mês em São Carlos foram obtidas através do site da Embrapa.

Observou-se como são distribuídos, hoje, os serviços de acordo com a pluviosidade, através de um gráfico, apresentado no capítulo 7 , de REMENDOS X MÊS e PLUVIOSIDADE X MÊS, para o período mais recente (janeiro até setembro de 2004).

Foi observada, também, através da plotagem de um gráfico de REMENDOS x PLUVIOSIDADE, referente ao período considerado, se existia alguma relação entre os dados, e qual seria a equação que descreveria a quantidade de remendos necessários de acordo com o índice pluviométrico. 


\section{ESTUDO DE CASO}

\subsection{Característica da cidade de São Carlos}

A cidade de São Carlos possui uma população estimada de 210.841 habitantes pelo Instituto Brasileiro de Geografia e Estatística - IBGE (2005). Tem características de uma cidade brasileira de médio porte e está localizada a 230 km da capital do Estado de São Paulo. Ainda segundo o IBGE (2005), a frota de veículos de São Carlos é de 78.084 veículos.

A área de São Carlos é de $1.141 \mathrm{~km}^{2}$, dos quais $55 \mathrm{~km}^{2}$ correspondem à área urbana, que possui aproximadamente $8.000 .000 \mathrm{~m}^{2}$ de vias urbanas (Figura 6.1).

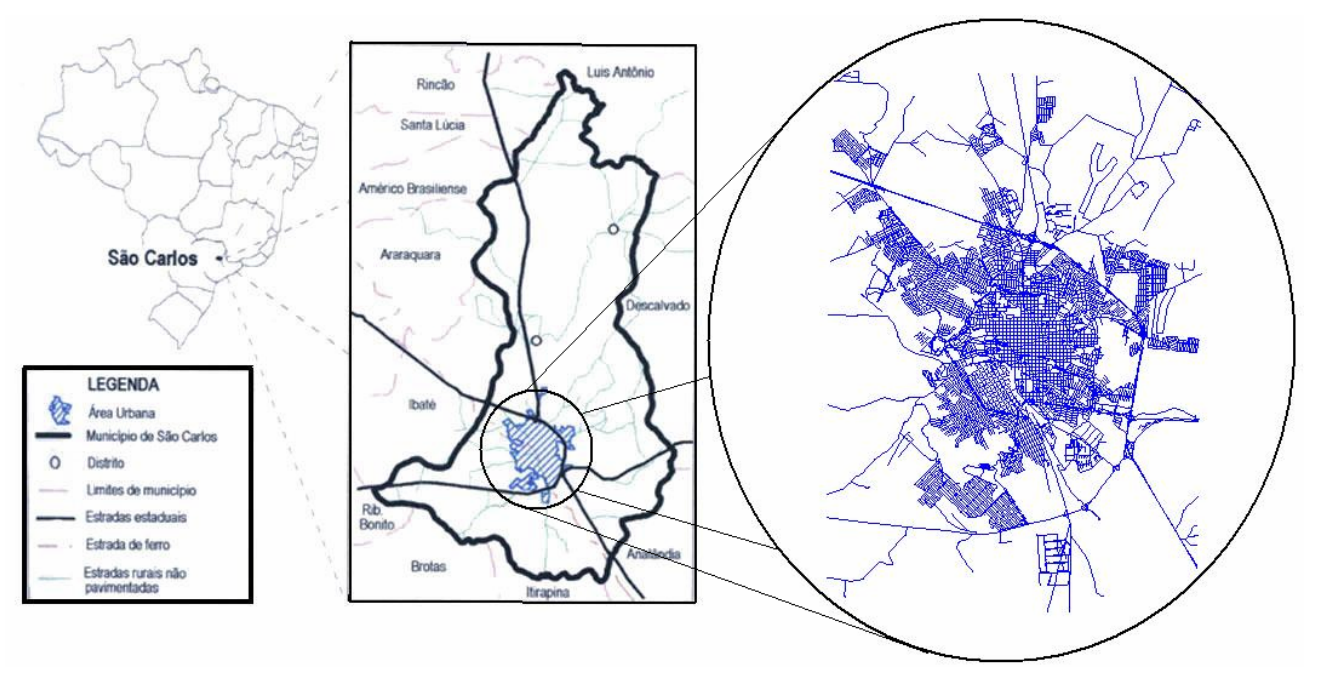

Figura 6.1 - Localização geográfica do município de São Carlos

O total das chuvas do mês mais seco em São Carlos não atinge $30 \mathrm{~mm}$, e o do mês mais chuvoso atinge valores dez ou mais vezes maiores do que os do mês mais seco, segundo a Embrapa Pecuária Sudeste - Embrapa (2005).

Ainda segundo a Embrapa, as precipitações anuais acumuladas variam entre 1.138 e 1593 mm e se concentram nos meses de outubro a março, sendo que $1 \mathrm{~mm}$ de água equivale à entrada de 1 litro $\mathrm{m}^{-2}$ ou $10 \mathrm{~m}^{3} \mathrm{ha}^{-1}$. 


\subsection{A manutenção das vias de São Carlos}

As vias urbanas, assim como sua manutenção, são uma das responsabilidades da Divisão de Vias Públicas da Secretaria de Obras, Transportes e Serviços Públicos de São Carlos.

Em São Carlos, como em grande parte dos municípios brasileiros, a manutenção dos pavimentos se mostra insuficiente e/ou ineficiente, não conseguindo atender a todas as ocorrências de panelas que surgem, o que só faz aumentar o problema, pois as panelas aumentam seu tamanho e quantidade, danificando ainda mais o pavimento e muitas vezes comprometendo-o por completo.

A Tabela 6.1 exemplifica isso, pois mostra que a aplicação dos recursos para o serviço de remendos não está correta, ocorrendo uma oscilação da quantidade de remendos com o passar dos anos, ao invés de uma diminuição, apesar da pluviosidade (uma das causas do aparecimento das panelas) se mostrar constante.

Tabela 6.1 - Quantidade de remendos executados e pluviosidade

\begin{tabular}{|c|c|c|c|c|}
\hline \multirow{2}{*}{ ANO } & \multirow{2}{*}{$\begin{array}{c}\text { Precipitação } \\
\text { (mm) }\end{array}$} & \multicolumn{3}{|c|}{ Remendos em Pavimentos $\left(\mathrm{m}^{2}\right)$} \\
\hline & & CBUQ & PMF & TOTAL \\
\hline 2.001 & 1201,6 & $33.221,51$ & $41.287,00$ & $74.508,51$ \\
\hline 2.002 & 1251,8 & $45.279,30$ & $56.476,00$ & $101.755,30$ \\
\hline 2.003 & 1158,8 & $35.185,84$ & $41.588,00$ & $76.773,84$ \\
\hline $2.004^{*}$ & 870,8 & $66.019,35$ & $48.640,73$ & $114.660,08$ \\
\hline
\end{tabular}

* até o mês de Setembro

Fonte: Divisão de Vias Públicas da Prefeitura de São Carlos

\subsubsection{O serviço de remendos nos pavimentos da cidade de São Carlos}

Durante a coleta de dados observou-se que o serviço de remendos em pavimentos era executado, em sua menor parte, por funcionários da Divisão de Vias Públicas (somente em emergências) e a maior parte por uma empresa privada contratada.

É tarefa das equipes contratadas não somente a execução de remendos nos pavimentos, mas também de lombadas e sarjetões, feitos com CBUQ, em diversos locais da cidade, a pedido da prefeitura. 
Os dados coletados para o estudo de caso referem-se à empresa privada contratada pela prefeitura para a manutenção dos pavimentos, mais especificamente dos dados referentes à execução dos remendos nos pavimentos.

Na cidade de São Carlos, o serviço de remendos tem seu ciclo desde o pedido feito pelo cidadão até sua execução, como ilustra a Figura 6.2.

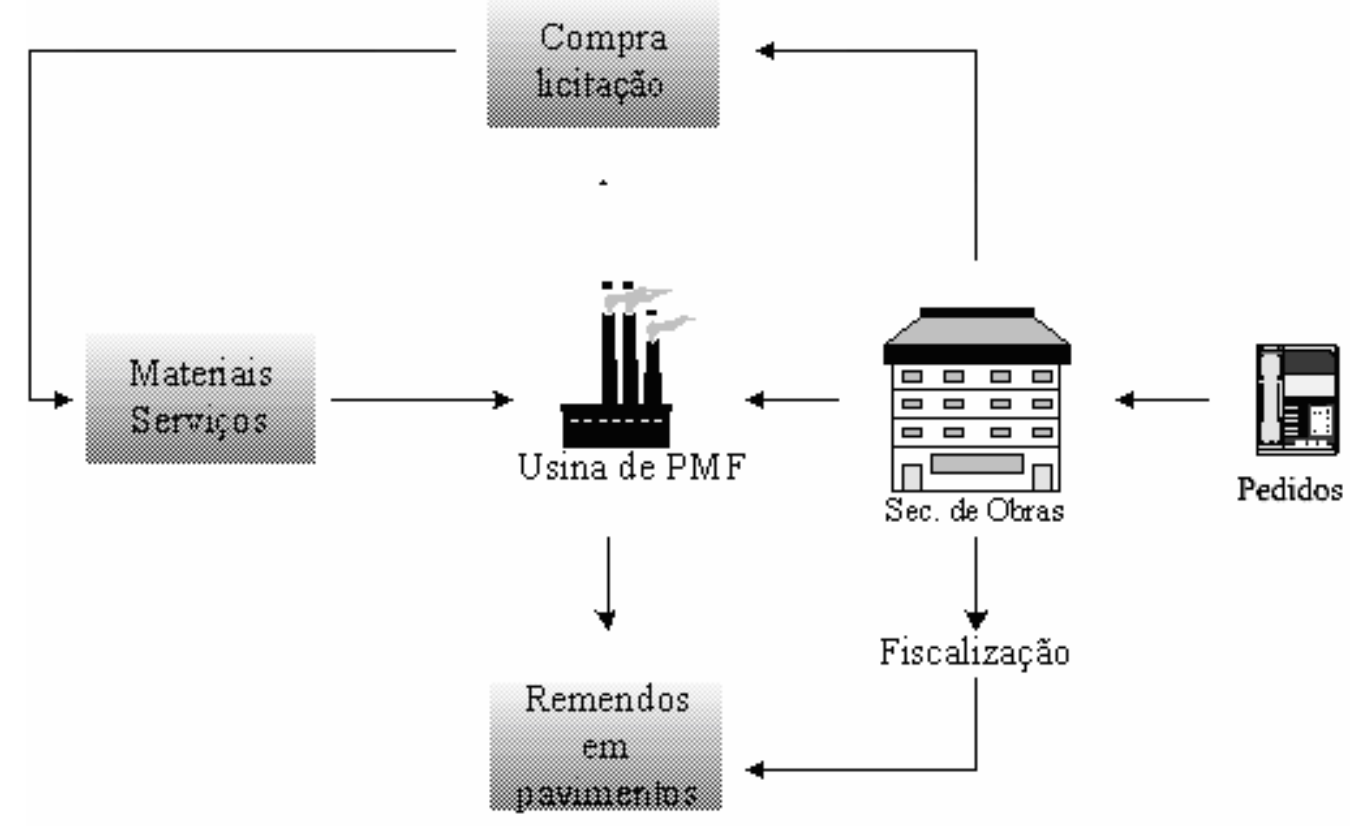

Figura 6.2 - Ciclo do pedido do serviço de remendos na cidade de São Carlos

Os pedidos pelo serviço de remendos são feitos em São Carlos de três maneiras:

- Pedidos diretos do prefeito ou vereadores;

- Pedidos feitos por cidadãos, através de ligação telefônica ou por escrito para a Prefeitura;

- Pedidos feitos por funcionários da Secretaria de Obras da Prefeitura, que durante seus serviços pelas ruas da cidade observam locais considerados críticos.

Segundo os engenheiros da prefeitura, todos os dias ocorrem, em média, 15 novos pedidos. 
As aquisições de mão de obra especializada, insumos como a emulsão asfáltica e os agregados para a fabricação do PMF são feitas por meio de licitações.

Os engenheiros do Setor de Obras Públicas transmitem as quantidades, prazos de contratos e orçamentos básicos dos insumos, materiais e serviços necessários ao setor de licitações da prefeitura.

O setor de licitações realiza, então, entre os fornecedores da prefeitura, licitações (Pregão, Tomada de Preços, Convite de Preços, Concorrência Pública) para a aquisição de tais insumos, materiais e serviços.

Existem dois critérios usados pelos engenheiros para se estimar os quantitativos de insumos, materiais e serviços e prazos para seu fornecimento:

- Histórico da quantidade gasta para realização do serviço no passado;

- A verba disponível no orçamento para a aquisição destes.

Em janeiros de 2004, a prefeitura contratou a execução de 57.000,00 $\mathrm{m}^{2}$ de remendos com PMF, que seriam fornecidos pela prefeitura, e de $100.000,00 \mathrm{~m}^{2}$ de remendos executados com CBUQ, que seriam fornecidos pela empresa contratada. $O$ contrato teria a duração de 2 anos.

A secretaria de obras informa então às suas equipes ou às equipes contratadas alguns locais onde devem ser executados remendos.

As equipes então se dirigem à usina da Prefeitura para carregar os caminhões com PMF ou para outra usina, quando vão utilizar o CBUQ.

A empresa contratada informa à Secretaria de Obras, a cada 30 dias, a quantidade total e a localização dos remendos executados nesse período.

O critério de medição da Prefeitura Municipal de São Carlos é a quantidade de metros quadrados de remendos efetuados, ou seja, o pagamento é efetuado de acordo com a quantidade de metros quadrados de remendos efetuados por mês.

A conferência do serviço é feita através de amostras escolhidas pela prefeitura, devido à falta de funcionários. 


\subsubsection{A execução do serviço}

Para a execução do serviço de remendos, a prefeitura possui uma usina para o fornecimento de PMF (Figura 6.3) e utiliza um caminhão emprestado do SAAE de São Carlos (Figura 6.4), que foi adaptado para carregar em compartimentos separados, a massa asfáltica, o pó de pedra, as ferramentas de trabalho e a emulsão asfáltica.

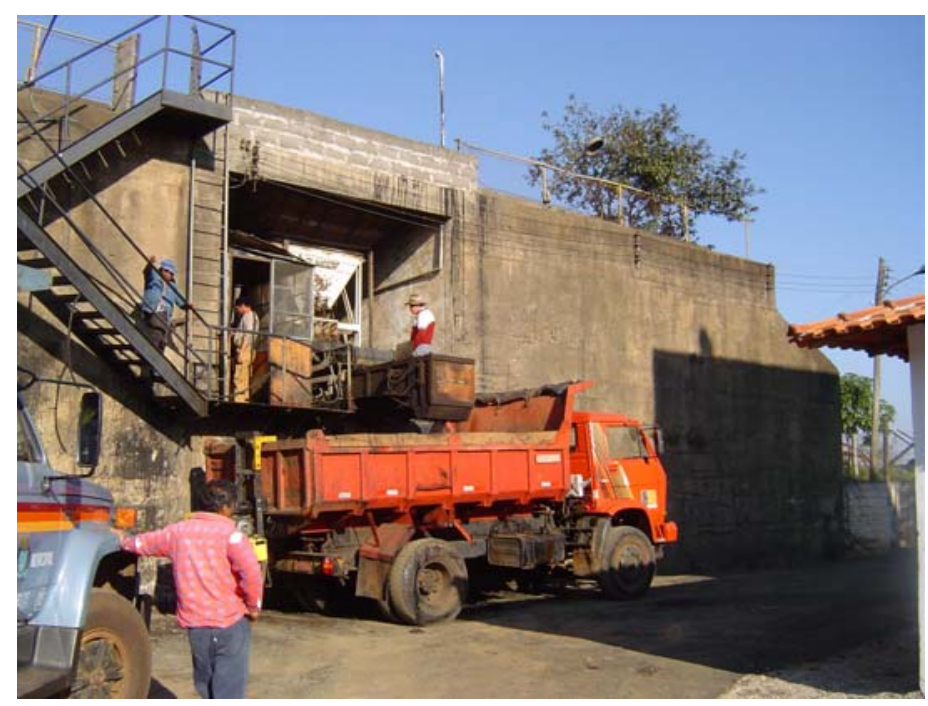

Figura 6.3 - Usina para preparação de PMF da Prefeitura Municipal de São Carlos

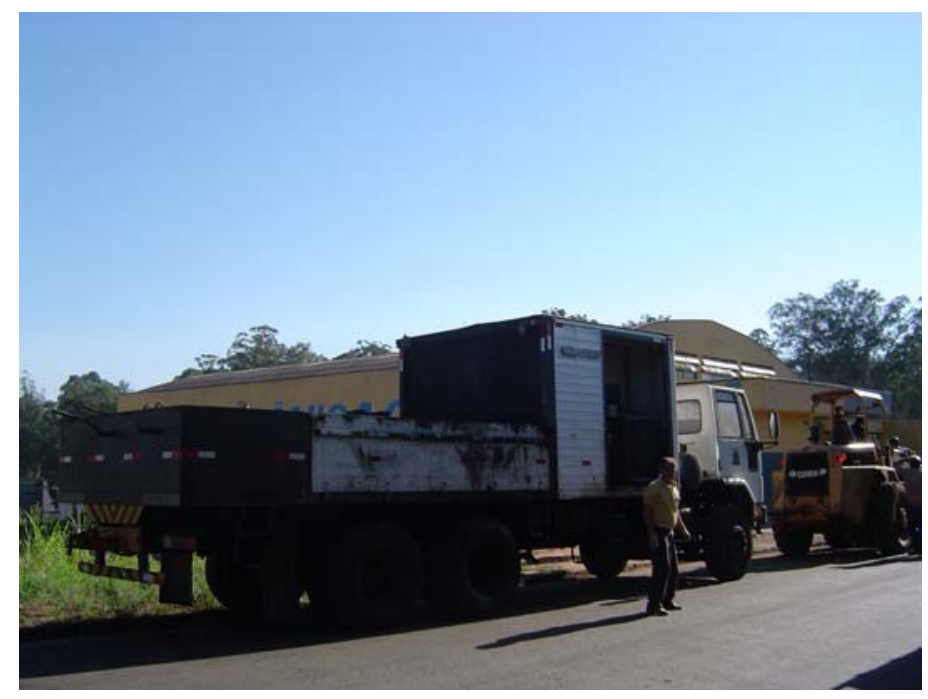

Figura 6.4 - Caminhão do SAAE de São Carlos para a execução de remendos

A equipe da prefeitura é composta por 5 pessoas, sendo 1 motorista. 
Porém, devido ao seu número reduzido de funcionários, a divisão de Vias Públicas de São Carlos realiza o serviço de remendos somente em emergências, utilizando tais funcionários prioritariamente para execução de pavimentação asfáltica em ruas e avenidas de São Carlos. Assim, a maioria do serviço de remendos em São Carlos fica a cargo da empresa DATEC.

A DATEC utiliza para esse serviço três equipes compostas cada uma por:

- Caminhão basculante de $5 \mathrm{~m}^{3}$, para levar a massa asfáltica (algumas vezes um caminhão de $10 \mathrm{~m}^{3}$ );

- Caminhão carroceria para levar o pó de pedra, ferramentas, cones para a sinalização, pessoal e tambores para carregar a emulsão asfáltica (Figura 6.5);

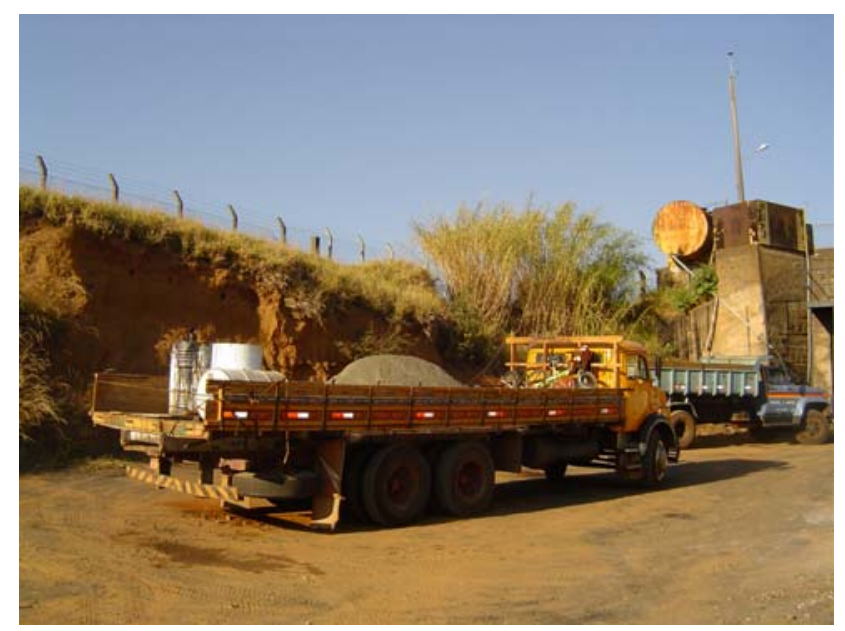

Figura 6.5 - Caminhão carroceria adaptado para levar os materiais necessários

- Rolo liso vibratório autopropulsor;

- 6 funcionários, sendo dois motoristas.

As equipes são divididas, geralmente, da seguinte maneira: duas trabalham com o PMF e a outra utiliza CBUQ.

Antes de iniciar os serviços, o encarregado pelo serviço de remendos da empresa DATEC recebe dos engenheiros da prefeitura o roteiro de serviços. 
O roteiro estabelecido não tem uma lógica pré-estabelecida ou locais com preferência para o serviço de remendos, como vias arteriais ou ruas do centro da cidade.

Somente procurava-se observar algumas condições como: completar serviços que por ventura ficaram inacabados no dia anterior ou trabalhar no centro da cidade entre 9:00 h e 16:30 h, que são horários de menor movimento nas ruas.

A falta de um roteiro elaborado, utilizando alguma técnica ou critério, torna o trabalho mais difícil e menos eficiente, pois muitas vezes as equipes têm que andar a procura de panelas nas ruas e isso também não possibilita a correta estimativa de materiais necessários, nem a correta alocação dos serviços.

Uma vez no local de trabalho, o serviço é realizado na seguinte seqüência:

1) Sinalização do local com cones;

2) Limpeza da área da panela com vassourões;

3) Execução de pintura de ligação com emulsão asfáltica RR-1C, utilizando um regador;

4) Aplicação da massa asfáltica com pá, forcados e enxadas;

5) Compactação do remendo com rolo liso vibratório;

6) Medição do serviço com uso de trena;

7) Aplicação de pó de pedra para evitar sua aderência nos veículos (somente quando do uso de PMF).

A seqüência acima descrita é ilustrada pelas Figuras $6.6,6.7,6.8,6.9$, $6.10,6.11$ e 6.12 . 


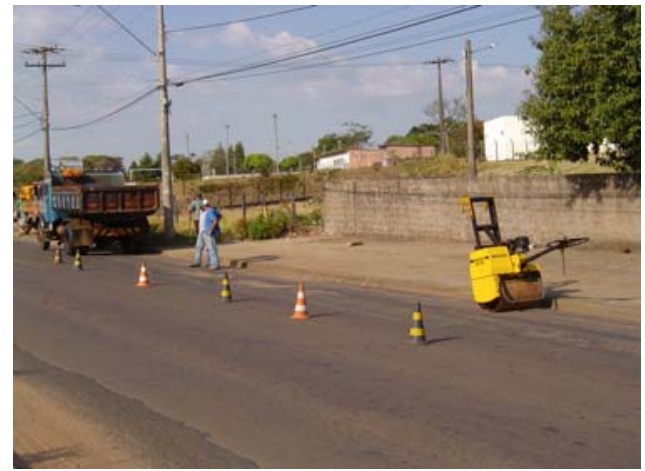

Figura 6.6 - Sinalização

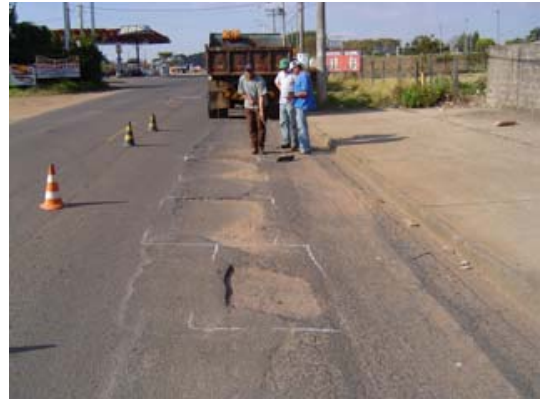

Figura 6.7 - Limpeza da área

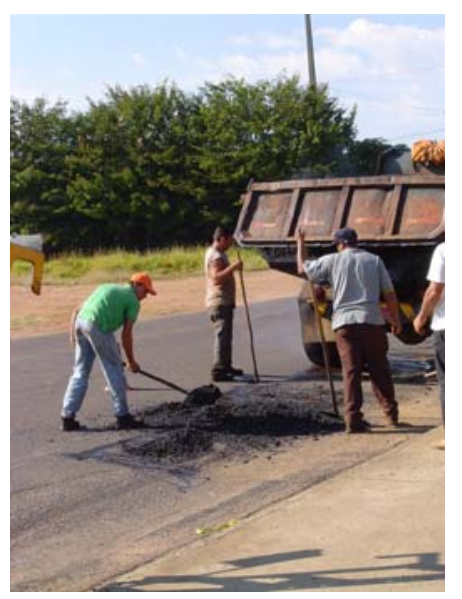

Figura 6.9 - Aplicação de massa asfáltica

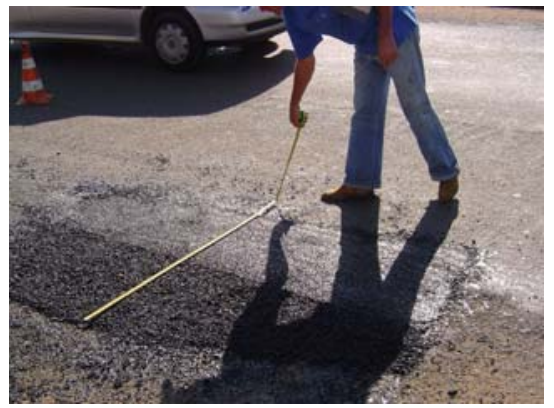

Figura 6.11 - Medição

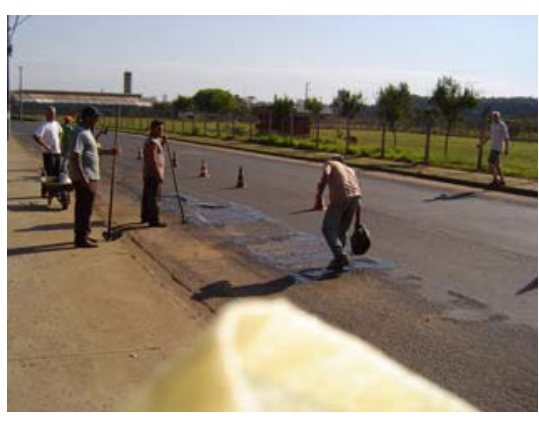

Figura 6.8- Pintura Ligante

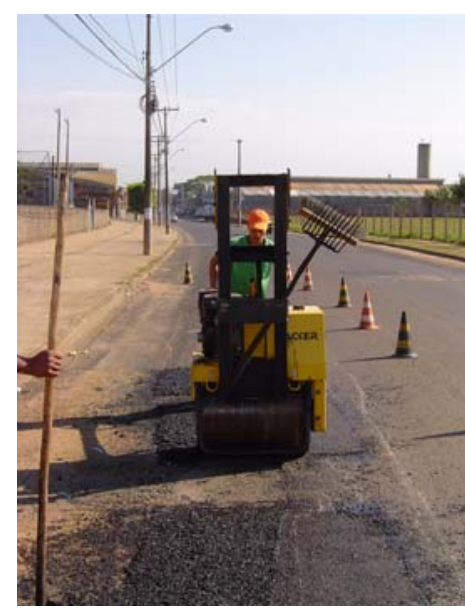

Figura 6.10 - Compactação

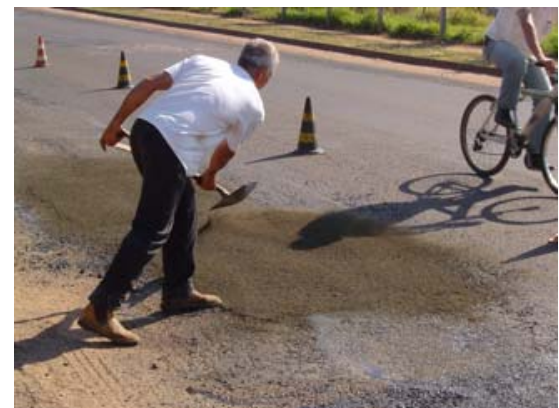

Figura 6.12 - Aplicação de pó de pedra 
Porém, o que se observa também é a falta de uma etapa nesse serviço, que é o corte da área afetada do pavimento. Tal etapa é citada como parte integrante do serviço, segundo o memorial descritivo elaborado pela prefeitura, e considerada importante, pois aumenta a qualidade e a durabilidade do serviço.

Outro fato observado algumas vezes, que também afeta a qualidade e a durabilidade do serviço, foi a execução de remendos em panelas úmidas ou sujas, e até algumas vezes a utilização do material retirado da limpeza (partes soltas do pavimento e sujeira) para completar as panelas, como mostra a Figura 6.13.

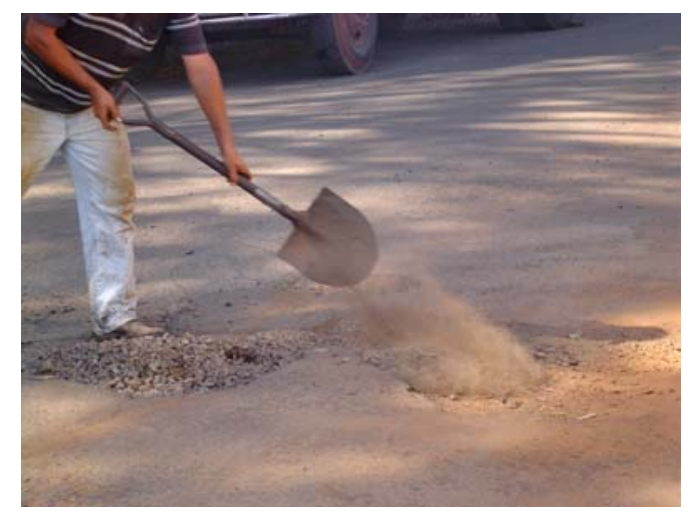

Figura 6.13 - Serviço executado de forma incorreta: uso de material solto para completar a panela

\subsection{A coleta de dados}

As equipes saem da garagem da empresa contratada todos os dias às 7:00 h da manhã e retornam aproximadamente as 17:00 h.

Durante quatro dias (de 27 de setembro até 30 de setembro de 2004) foi entregue aos motoristas de cada uma das equipes a planilha ilustrada na Figura 5.2.

Após as instruções do engenheiro da DATEC e a distribuição dos roteiros de somente algumas panelas a serem remendadas, as equipes se dirigiam para a usina da prefeitura, no caso da utilização de PMF, ou para outra usina, quando da utilização de CBUQ.

Nos dias da coleta de dados, somente em um dia foi utilizado o CBUQ e ele foi carregado num caminhão com capacidade para $10 \mathrm{~m}^{3}$. 
Assim, durante as simulações do TransCAD foi considerado o uso de um caminhão de $10 \mathrm{~m}^{3}$ de capacidade, durante um dia.

Foi feito o acompanhamento do trabalho de uma equipe em cada dia diferente, para verificar os procedimentos adotados por cada uma delas, fotografar a seqüência dos trabalhos e acompanhar as dificuldades que 0 serviço de remendos apresenta, como por exemplo, a procura por panelas nas ruas.

Uma preocupação do trabalho foi a observação da temperatura do CBUQ utilizado durante o serviço de remendos. Para isso, em outra oportunidade foi acompanhada uma equipe que trabalhava com CBUQ.

A cada parada do caminhão a temperatura da massa era medida e até o final do dia ela não se mostrou inadequada para sua aplicação, ficando sempre acima do $130^{\circ} \mathrm{C}$. 


\section{RESULTADOS}

\subsection{Resultados obtidos em campo}

Até o mês de Setembro de 2004, aproximadamente $125.000 \mathrm{~m}^{2}$ de remendos foram executados, restando pouco mais de $32.000 \mathrm{~m}^{2}$ para os outros 15 meses de contrato. Mesmo com a utilização de quase todo a quantidade contratada, o que se observa, andando pela cidade, é que o problema de panelas das vias urbanas de São Carlos está longe de ser resolvido.

Em junho de 2005, o serviço de remendos em pavimento esteve somente a cargo dos funcionários da Divisão de Vias Públicas, que não possui número suficiente de funcionários para o serviço.

$\mathrm{Em}$ algumas ruas foram executados remendos de dimensões muito grandes, chegando a $200 \mathrm{~m}^{2}$. Para superfícies muito grandes o ideal seria o recapeamento asfáltico ou até mesmo a reconstrução do pavimento, caso a estrutura toda do pavimento estivesse comprometida.

Essa medida seria mais eficiente, pois o serviço seria executado com equipamentos adequados (vibro-acabadoras, rolo compactador de pneu e rolo compactador tandem etc.), que garantiriam as espessuras corretas das camadas do pavimento e um acabamento melhor dessas camadas, livre de ondulações e imperfeições.

Existe também o problema do excesso de remendos em algumas vias, como por exemplo a Travessa 1 (Figura 7.1). Nessa via foram executadas $120,40 \mathrm{~m}^{2}$ de remendos em apenas 73 metros de rua, durante o período da manhã (aproximadamente das oito até as onze horas da manhã). 


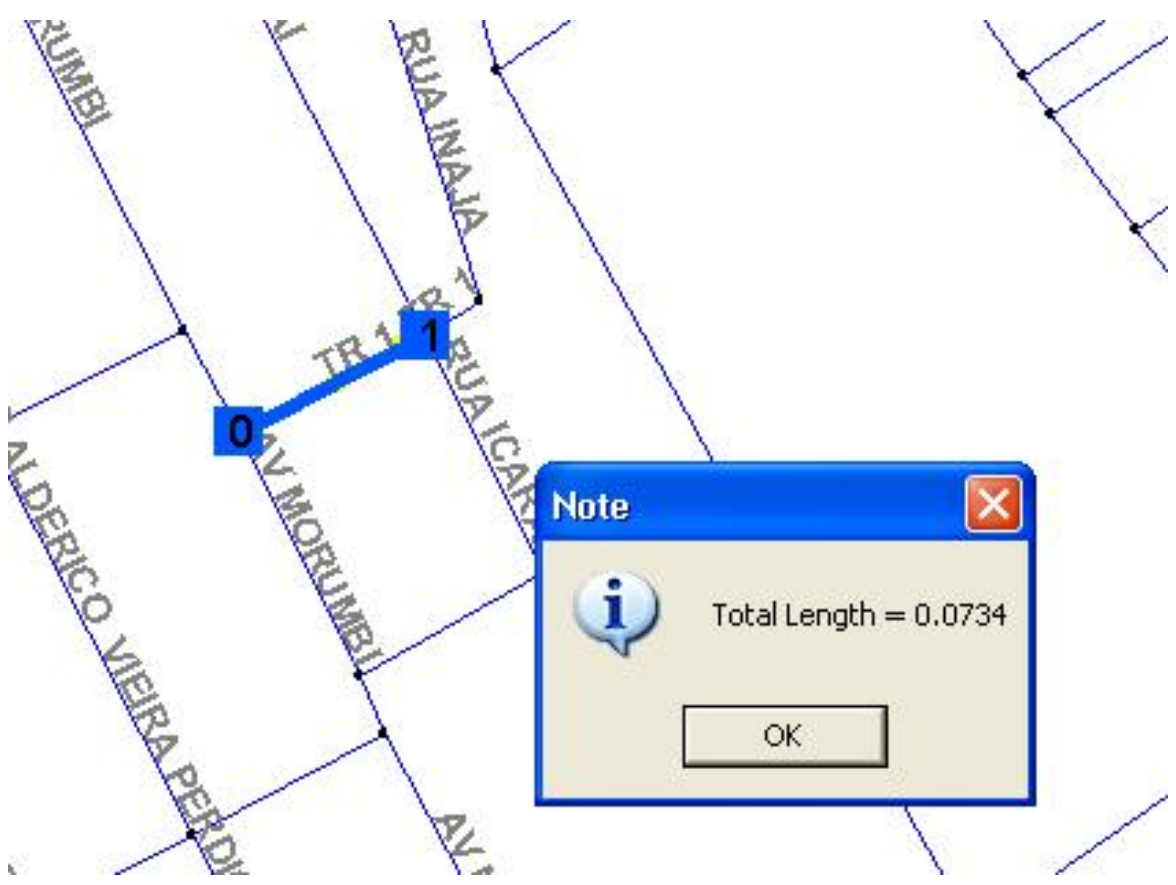

Figura 7.1 - Remendos executados na Travessa 1 no dia 29/09/2004

Para as vias que possuem muitas panelas, também seria mais adequado o recapeamento asfáltico ou a reconstrução do pavimento, pois esse pavimento provavelmente está comprometido devido à infiltração de água, pela falta de grande parte de seu revestimento e até de algumas camadas (capa e base).

A reconstrução garantiria um pavimento de qualidade superior ao pavimento remendado e, provavelmente, com uma relação benefício/custo maior, pois o preço unitário do metro quadrado de pavimentação é, geralmente, menor que o preço por metro quadrado de remendo.

Os roteiros elaborados sem nenhuma técnica (rota azul), conforme mostra a Figura 7.2, levam as equipes a percorrer distâncias muito grandes para efetuar seus remendos, passando muitas vezes por áreas com panelas mais próximas (pontos amarelos), que acabam sendo remendadas por outras equipes. 


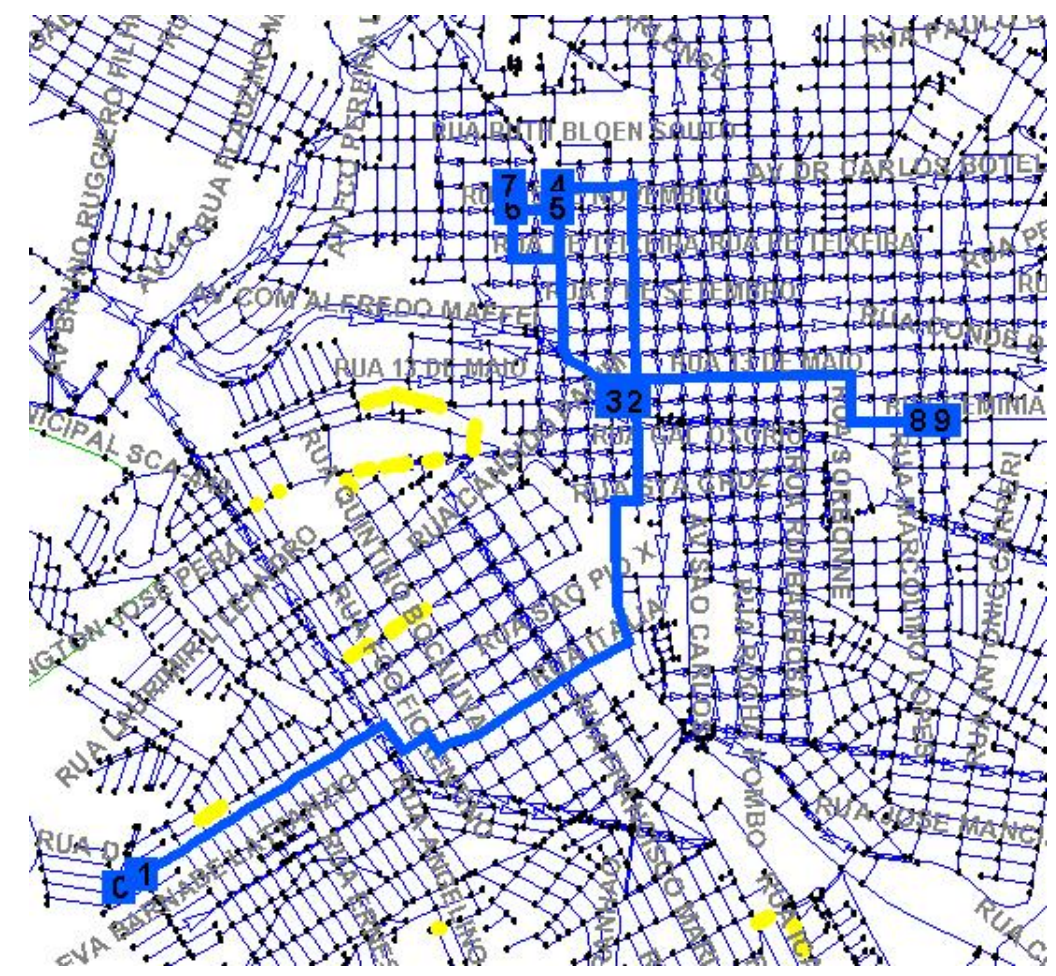

Figura 7.2 - Roteiro inadequado, efetuado no dia 28/09/2004

Alguns roteiros apresentam rendimento muito baixo, como o roteiro exposto na Figura 7.3, que mostra o itinerário de uma equipe no dia $30 / 09 / 2004$.

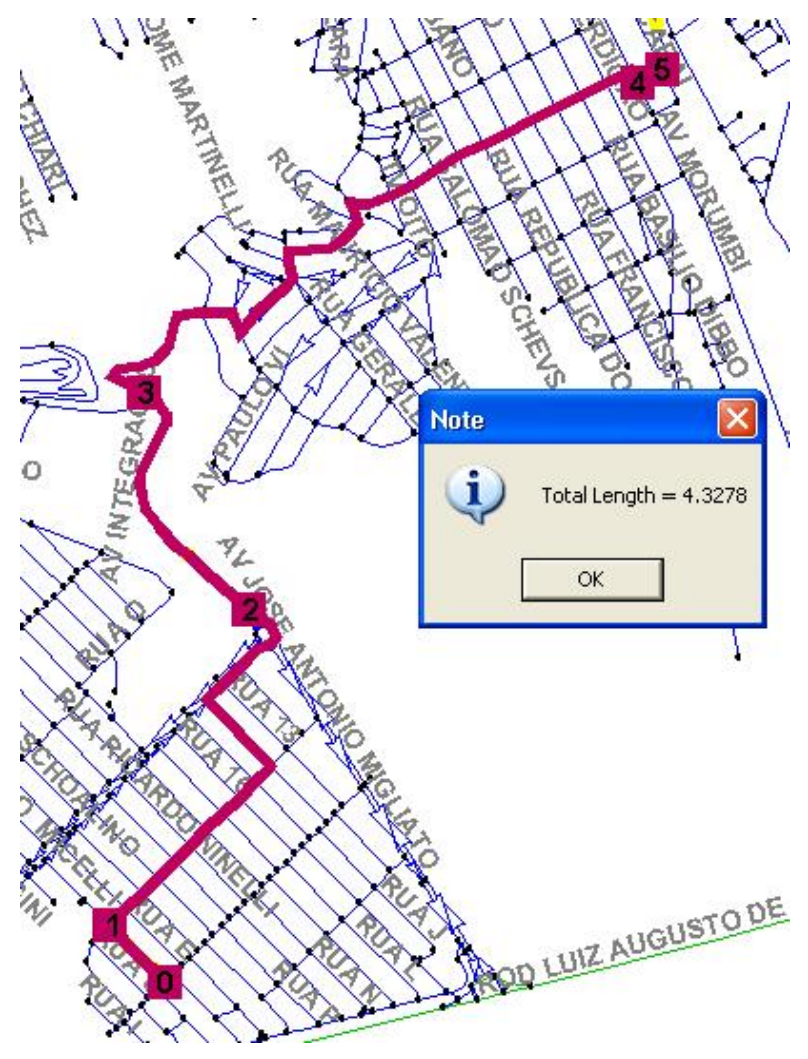

Figura 7.3 - Roteiro com baixo rendimento, efetuado no dia 30/09/2004 
Neste itinerário percorreu 4,3 $\mathrm{km}$ de vias para executar $138,43 \mathrm{~m}^{2}$ de remendos em oito horas de serviço, lembrando que a quilometragem apresentada se refere somente à distância entre o primeiro e o último remendo executado, excluindo-se as distâncias até a garagem e até a usina.

As Tabelas 7.1 e 7.2 apresentam os dados coletados de cada equipe durante o período de observação, com o uso do croqui de localização do serviço de cada equipe e da planilha ilustrada na Figura 5.1.

Tabela 7.1 - Quantidades de remendos executados e quilometragem percorrida por equipe observada durante o período de estudo

\begin{tabular}{|c|c|c|c|c|}
\hline Dia & Equipe & Turnos & $\begin{array}{l}\text { Remendo Total } \\
\left(\mathrm{m}^{2}\right)\end{array}$ & $\begin{array}{l}\text { Quilometragem } \\
(\mathrm{km})\end{array}$ \\
\hline \multirow{3}{*}{27} & 1 & 2 & 248,38 & 27,17 \\
\hline & 2 & 2 & 207,16 & 17,45 \\
\hline & 3 & 2 & 394,15 & 22,14 \\
\hline \multirow{4}{*}{28} & 1 & 2 & 251,71 & 26,27 \\
\hline & 2 & 2 & 228,75 & 17,82 \\
\hline & 3 & 2 & 305,46 & 20,44 \\
\hline & $4^{*}$ & 1 & 269,43 & 45,00 \\
\hline \multirow{3}{*}{29} & 1 & 2 & 216,15 & 11,82 \\
\hline & 2 & 1 & 141,85 & 9,41 \\
\hline & 3 & 2 & 264,99 & 22,07 \\
\hline \multirow{3}{*}{30} & 1 & 2 & 256,61 & 10,12 \\
\hline & 2 & 1 & 203,34 & 9,85 \\
\hline & 3 & 1 & 161,92 & 19,12 \\
\hline total & 13 & 22 & $3.149,90$ & 258,68 \\
\hline
\end{tabular}

Um turno corresponde a cada vez que o caminhão é carregado na usina de PMF ou CBUQ.

A média de remendos executados por cada equipe que utilizou o caminhão com capacidade de $5 \mathrm{~m}^{3}$ foi de $240,04 \mathrm{~m}^{2}$. Essa média é importante na etapa de roteirização do TransCAD, como explicado no capítulo 5.

O caminhão com capacidade para $10 \mathrm{~m}^{3}$ foi utilizado somente uma vez durante os serviços, sendo o único que possuía um hodômetro que funcionava. Ele foi sub-utilizado, carregado com aproximadamente $8 \mathrm{~m}^{3}$ de CBUQ no dia 28/09/2004 e foi considerado na simulação do TransCAD. 
Os cálculos dos tempos, estimados através dos dados coletados com 0 uso da planilha entregue aos motoristas (Figura 5.2), são demonstrados na Tabela 7.2.

As colunas marcam, respectivamente, o horário de chegada de cada equipe a garagem (Chegada Garagem), o horário de saída da usina (Saída Usina 1), o tempo gasto na usina em uma eventual segunda carga (Tempo Usina 2), e o tempo gasto para o almoço (estimado em uma hora por equipe).

O Tempo Trabalhado é calculado subtraindo-se do horário de chegada à garagem o horário de saída da usina, o tempo gasto na usina na segunda carga e o tempo de almoço.

Tabela 7.2 -Tempos gastos por equipe durante o período de estudo

\begin{tabular}{|c|c|c|c|c|c|c|}
\hline Dia & Equipe & $\begin{array}{c}\text { Chegada } \\
\text { Garagem } \\
\text { (h) }\end{array}$ & $\begin{array}{l}\text { Saída } \\
\text { Usina } 1 \\
\text { (h) }\end{array}$ & $\begin{array}{c}\text { Tempo Usina } \\
2 \\
\text { (h) }\end{array}$ & $\begin{array}{c}\text { Almoço } \\
\text { (h) }\end{array}$ & $\begin{array}{c}\text { Tempo } \\
\text { Trabalhado } \\
\text { (h) }\end{array}$ \\
\hline \multirow{3}{*}{27} & 1 & $17: 00: 00$ & $7: 50: 00$ & $0: 30: 00$ & 1:00:00 & 7:40:00 \\
\hline & 2 & $16: 30: 00$ & 8:05:00 & $0: 35: 00$ & 1:00:00 & $6: 50: 00$ \\
\hline & 3 & $17: 10: 00$ & 8:00:00 & 0:20:00 & 1:00:00 & 7:50:00 \\
\hline \multirow{4}{*}{28} & 1 & $16: 45: 00$ & $7: 55: 00$ & $0: 30: 00$ & $1: 00: 00$ & 7:20:00 \\
\hline & 2 & 16:50:00 & 8:05:00 & 0:25:00 & 1:00:00 & 7:20:00 \\
\hline & 3 & $16: 45: 00$ & $8: 30: 00$ & $0: 25: 00$ & 1:00:00 & 6:50:00 \\
\hline & 4 & 17:30:00 & 9:20:00 & 0:00:00 & 1:00:00 & 7:10:00 \\
\hline \multirow{3}{*}{29} & 1 & $16: 45: 00$ & 7:55:00 & 0:30:00 & 1:00:00 & 7:20:00 \\
\hline & 2 & $15: 40: 00$ & $8: 15: 00$ & 0:00:00 & 1:00:00 & $6: 25: 00$ \\
\hline & 3 & $16: 43: 00$ & $7: 50: 00$ & 1:20:00 & 1:00:00 & 6:33:00 \\
\hline \multirow{3}{*}{30} & 1 & $16: 00: 00$ & $7: 50: 00$ & 0:30:00 & 1:00:00 & $6: 40: 00$ \\
\hline & 2 & 15:00:00 & $7: 45: 00$ & 0:00:00 & 1:00:00 & $6: 15: 00$ \\
\hline & 3 & $16: 00: 00$ & 8:00:00 & 0:00:00 & 1:00:00 & 7:00:00 \\
\hline
\end{tabular}

A Tabela 7.3 foi composta a partir dos dados somados das planilhas Tabelas 7.1 e 7.2. A partir dos dados dessa planilha, e com o uso das equações apresentadas no capítulo 5 , foi estimada a velocidade de operação de $0,09 \mathrm{~km} / \mathrm{h}$ utilizada no TransCAD, como apresentado no capítulo 5 . 
Tabela 7.3 - Quantidades e tempos totais do serviço de remendos em pavimentos observados durante o período de estudo

\begin{tabular}{ccccccc}
\hline DIA & Quantidade & Quilometragem & Quilometragem & Tempo & $\begin{array}{c}\text { Tempo } \\
\text { Trabalhado } \\
(\mathrm{h})\end{array}$ & $\begin{array}{c}\text { Quantidade } \\
\text { Total }\left(\mathrm{m}^{2}\right)\end{array}$ \\
\hline 27/set & 3 & 66,76 & 1,27 & $26: 10: 00$ & $22: 20: 00$ & 849,69 \\
28/set & 4 & 109,53 & 1,74 & $35: 05: 00$ & $28: 40: 00$ & $1.055,35$ \\
29/set & 3 & 43,3 & 2,18 & $24: 53: 00$ & $20: 18: 00$ & 622,99 \\
30/set & 3 & 39,09 & 1,85 & $22: 40: 00$ & $19: 55: 00$ & 621,87 \\
Total & 13 & 258,68 & 7,04 & $108: 48: 00$ & $91: 13: 00$ & $3.149,90$ \\
média & 3,25 & 19,90 & 0,54 & $08: 22: 09$ & $07: 01: 00$ & 242,30 \\
\hline
\end{tabular}

A coluna tempo total é a soma das horas trabalhadas por cada equipe no dia, desde a sua saída até o retorno à garagem.

A coluna tempo trabalhado é a soma de cada dia da coluna tempo trabalhado da Tabela 7.2.

A quilometragem de roteiro é a soma das distâncias somente dos links onde foram executados remendos. Ela foi estimada com o auxílio do TransCAD, usando-se também o comando Network/Paths-Shortest Path.

\subsection{Resultados obtidos com o TransCAD}

A Tabela 7.4 contém os resultados obtidos pela ferramenta de roteirização em arco, separados por territórios (de acordo com a separação dos pontos de serviço, explicada no capítulo 5),

Cada território possui uma determinada quantidade de turnos (shifts) necessária para se executar os serviços, com uma quantidade diferente de horas trabalhadas. A quilometragem percorrida apresentada para cada turno de serviço considera, inclusive a distância para recarregar o caminhão ou para o retorno à garagem. Para isso utilizou-se a ferramenta Network/Paths-Shortest Path.

A partir da Tabela 7.4 foi elaborada a Tabela 7.5 , que possui as rotas geradas, agrupadas em 3 dias, um dia a menos que os dados coletados, uma vez que o resultado gerado pelo TransCAD possibilitou tal redução. 
Tabela 7.4 - Resultados do TransCAD para a roteirização em arco

\begin{tabular}{|c|c|c|c|c|}
\hline Território & Turno & $\begin{array}{l}\text { Quilometragem } \\
\text { Total }(\mathrm{km})\end{array}$ & $\begin{array}{c}\text { Tempo } \\
\text { Trabalhado (h) }\end{array}$ & $\begin{array}{c}\text { Remendos } \\
\left(\mathrm{m}^{2}\right)\end{array}$ \\
\hline \multirow{3}{*}{1} & 1 & 18,90 & 7:30:48 & 232,33 \\
\hline & 2 & 10,79 & 1:42:08 & 220,29 \\
\hline & 3 & 17,37 & 3:40:17 & 62,64 \\
\hline \multirow{2}{*}{2} & 1 & 10,55 & 8:23:36 & 239,72 \\
\hline & 2 & 11,07 & $6: 15: 27$ & 238,09 \\
\hline 3 & 1 & 11,16 & $2: 30: 57$ & 80,18 \\
\hline \multirow{4}{*}{4} & 1 & 10,72 & $6: 40: 31$ & 231,88 \\
\hline & 2 & 9,64 & $5: 32: 13$ & 222,33 \\
\hline & 3 & 4,72 & 2:05:19 & 225,35 \\
\hline & 4 & 6,28 & 4:39:45 & 94,04 \\
\hline \multirow{3}{*}{5} & 1 & 10,86 & 1:48:10 & 236,44 \\
\hline & 2 & 13,74 & 2:08:26 & 226,21 \\
\hline & 3 & 15,15 & $1: 12: 29$ & 225,90 \\
\hline \multirow{3}{*}{6} & 1 & 11,04 & 2:27:43 & 210,16 \\
\hline & 2 & 5,56 & 3:02:33 & 235,47 \\
\hline & 3 & 14,30 & $5: 11: 46$ & 168,87 \\
\hline Total & & 181,85 & $64: 52: 08$ & $3.149,90$ \\
\hline
\end{tabular}

O agrupamento dos diversos turnos em rotas foi feito procurando deixar que cada equipe trabalhasse aproximadamente 7 horas por dia e que a quantidade máxima de remendos executados em cada turno fosse limitada a $240,04 \mathrm{~m}^{2}$, quantidade média de remendos executados por equipes que utilizam o caminhão mais comum, com capacidade para $5 \mathrm{~m}^{3}$.

A quantidade de 7 horas trabalhadas por dia é a média de horas trabalhadas que foi observada durante a coleta de dados e pode ser verificada através da Tabela 7.3.

Outro critério foi o uso da mesma quantidade de equipes que a empresa dispunha, quando da coleta de dados, e a utilização de um caminhão com o dobro de capacidade $\left(10 \mathrm{~m}^{3}\right)$ durante um dia de serviço. 
Tabela 7.5 - Resultados do TransCAD agrupados em três dias de trabalho

\begin{tabular}{ccccc}
\hline DIA & $\begin{array}{c}\text { Quantidade } \\
\text { de Equipes }\end{array}$ & $\begin{array}{c}\text { Quilometragem } \\
\text { Total }(\mathrm{Km})\end{array}$ & $\begin{array}{c}\text { Tempo } \\
\text { Trabalhado }(\mathrm{h})\end{array}$ & $\begin{array}{c}\text { Quantidade } \\
\text { Total }\left(\mathrm{m}^{2}\right)\end{array}$ \\
\hline 1 & 3 & 46,89 & $23: 05: 06$ & 646,27 \\
2 & 4 & 104,03 & $27: 17: 16$ & 1861,2 \\
3 & 2 & 30,93 & $14: 29: 46$ & 642,43 \\
Total & 9 & 181,85 & $64: 52: 08$ & 3149,9 \\
média & 3 & 20,21 & $7: 12: 28$ & 349,99 \\
\hline
\end{tabular}

O Tempo Trabalhado é o tempo gasto para percorrer todos os links, de acordo com as velocidades estimadas no capítulo 5, sem contabilizar as horas de almoço e o tempo gasto para carregar o caminhão na usina.

O que se observa é que, para a mesma quantidade de remendos, a roteirização em arco traz resultados muito melhores que o método utilizado para a definição dos roteiros atuais.

As equipes passaram a ter, teoricamente, um rendimento maior. Para a roteirização em arco, as equipes percorrem em média 20,21 km e executam $349,99 \mathrm{~m}^{2}$ por dia, enquanto na coleta de dados as equipes percorriam em média 19,90 km e executavam 242,30 $\mathrm{m}^{2}$ de remendos diariamente.

A quilometragem média percorrida por equipe não melhorou significativamente, porém, com a roteirização, a quantidade de equipes necessárias diminui em 30,77\%, passando de treze para nove.

Ocorreram melhoras também na quilometragem total percorrida, que diminuiu em $29,70 \%$ e no tempo trabalhado, que diminuiu em $28,89 \%$.

Isso significa que a mesma quantidade de serviço pode ser feita com um número menor de equipes e num tempo menor (três dias de serviço). Assim, os gastos podem ser diminuídos, pois, as equipes vão percorrer uma distância total menor, e o mesmo número de funcionários executará uma quantidade maior de serviço.

A melhora na quilometragem total percorrida pode ser ainda maior, pois na ocasião da coleta de dados, a quilometragem de cada caminhão foi estimada com o uso do TransCAD e não com o hodômetro de cada caminhão, como explicado anteriormente no capítulo 5. 
Observa-se também que a roterização possibilita uma programação melhor das equipes, evitando que algumas trabalhem mais que as outras.

Os roteiros gerados pelo TransCAD são expostos nas Figuras 7.4, 7.5, 7.6, 7.7, 7.8, 7.9 e 7.10.

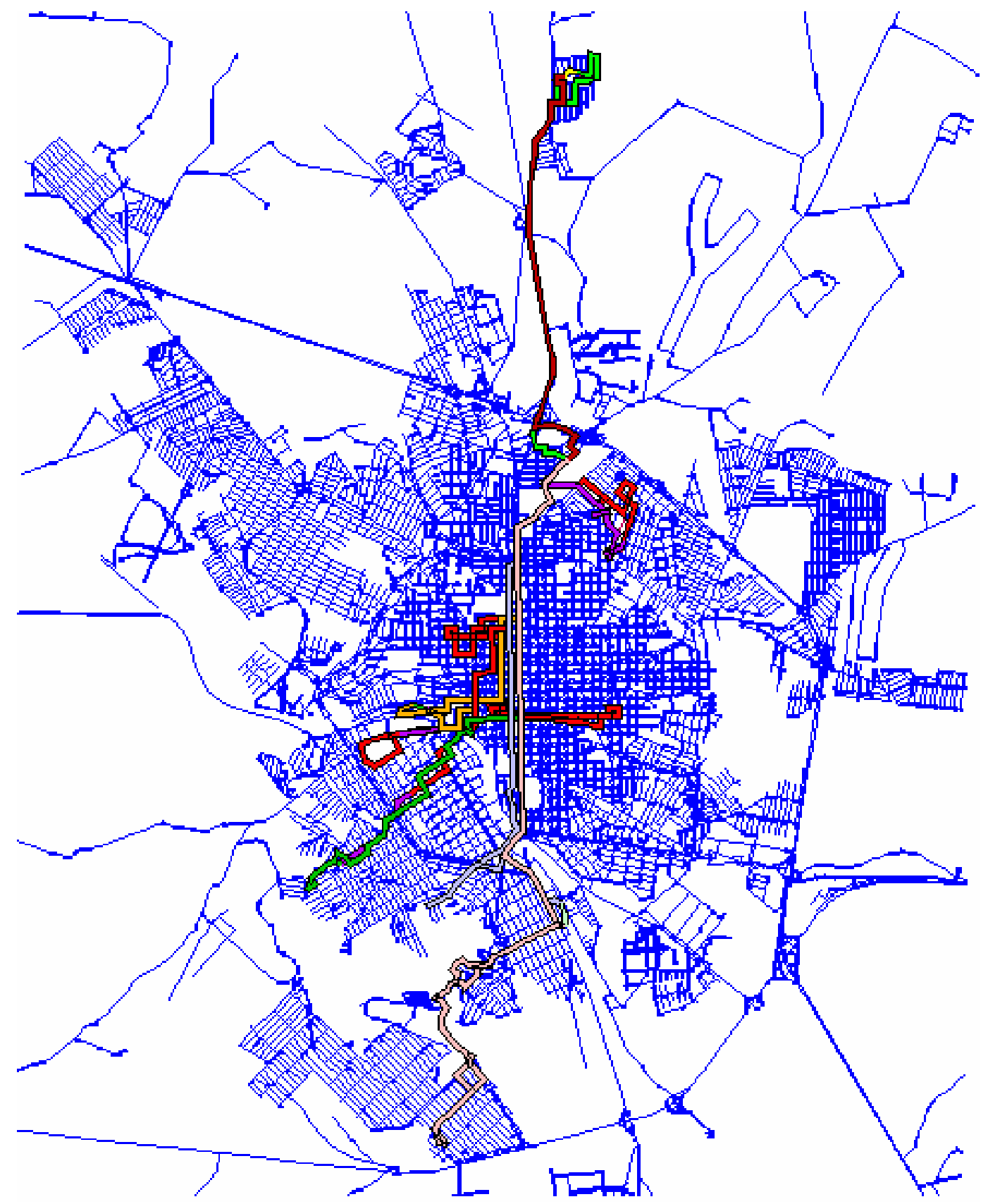

Figura 7.4 - Todos os roteiros gerados pelo TransCAD 


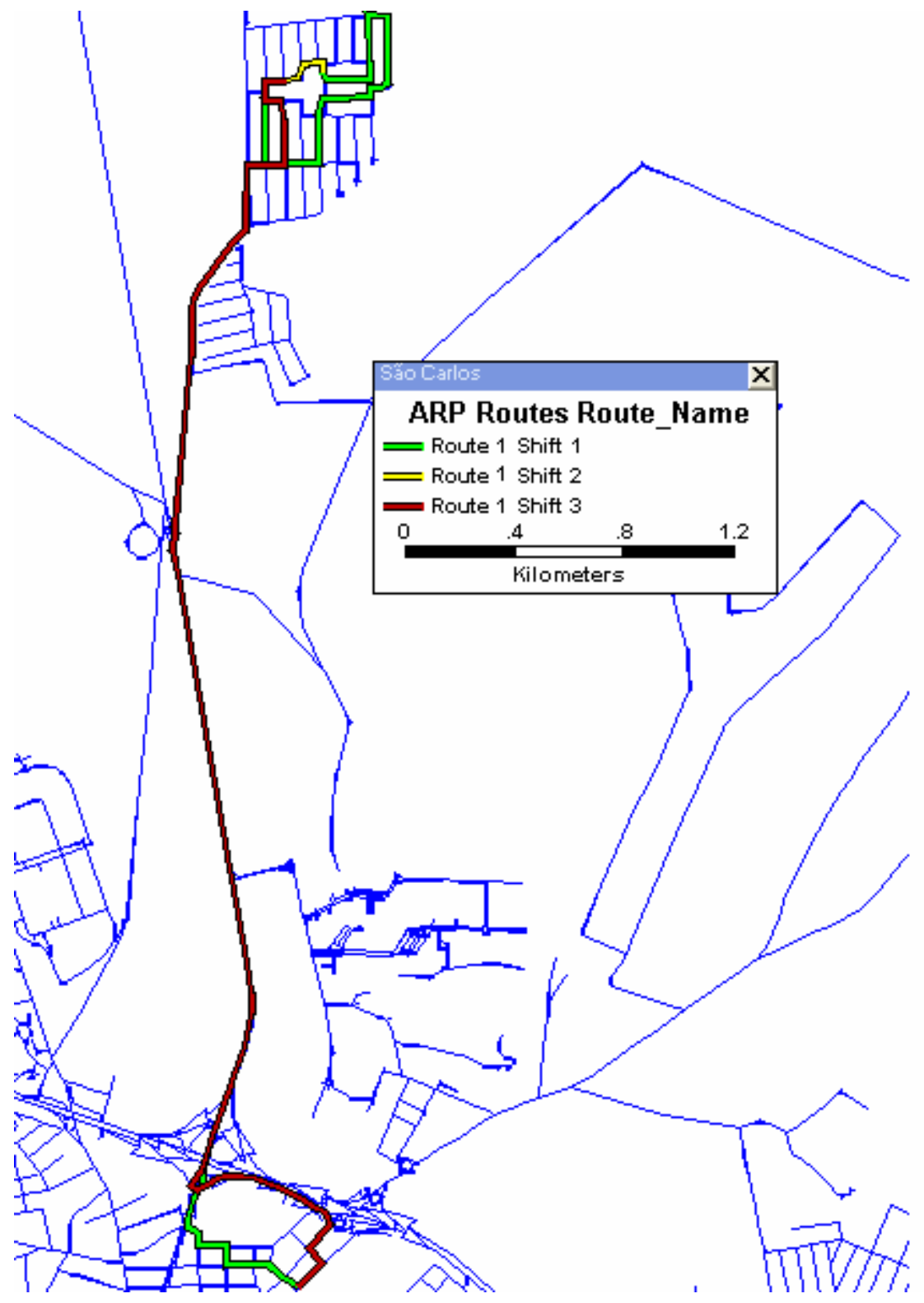

Figura 7.5 - Detalhe do roteiro da região 1 


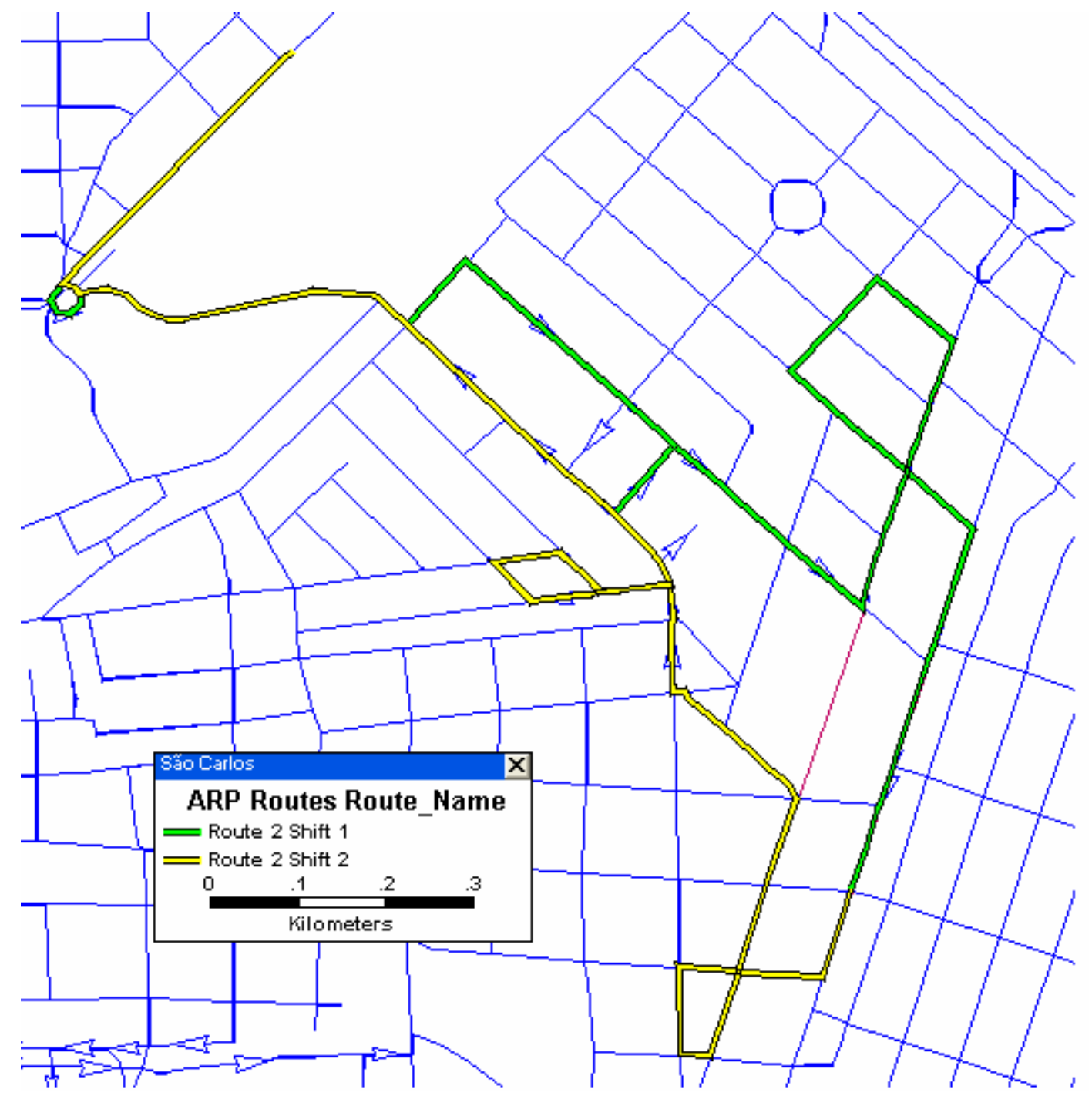

Figura 7.6 - Detalhe do roteiro da região 2 


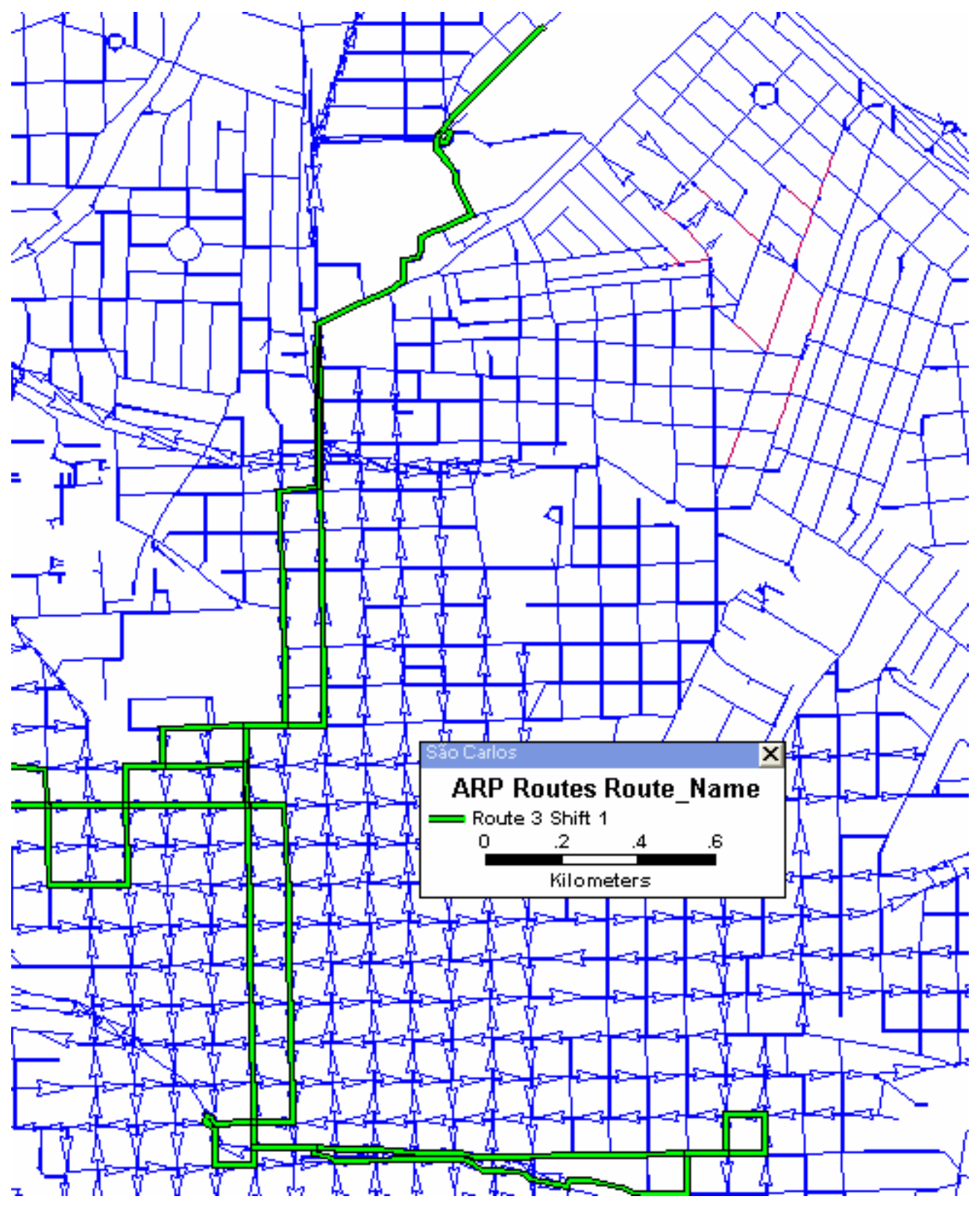

Figura 7.7 - Detalhe do roteiro da região 3 


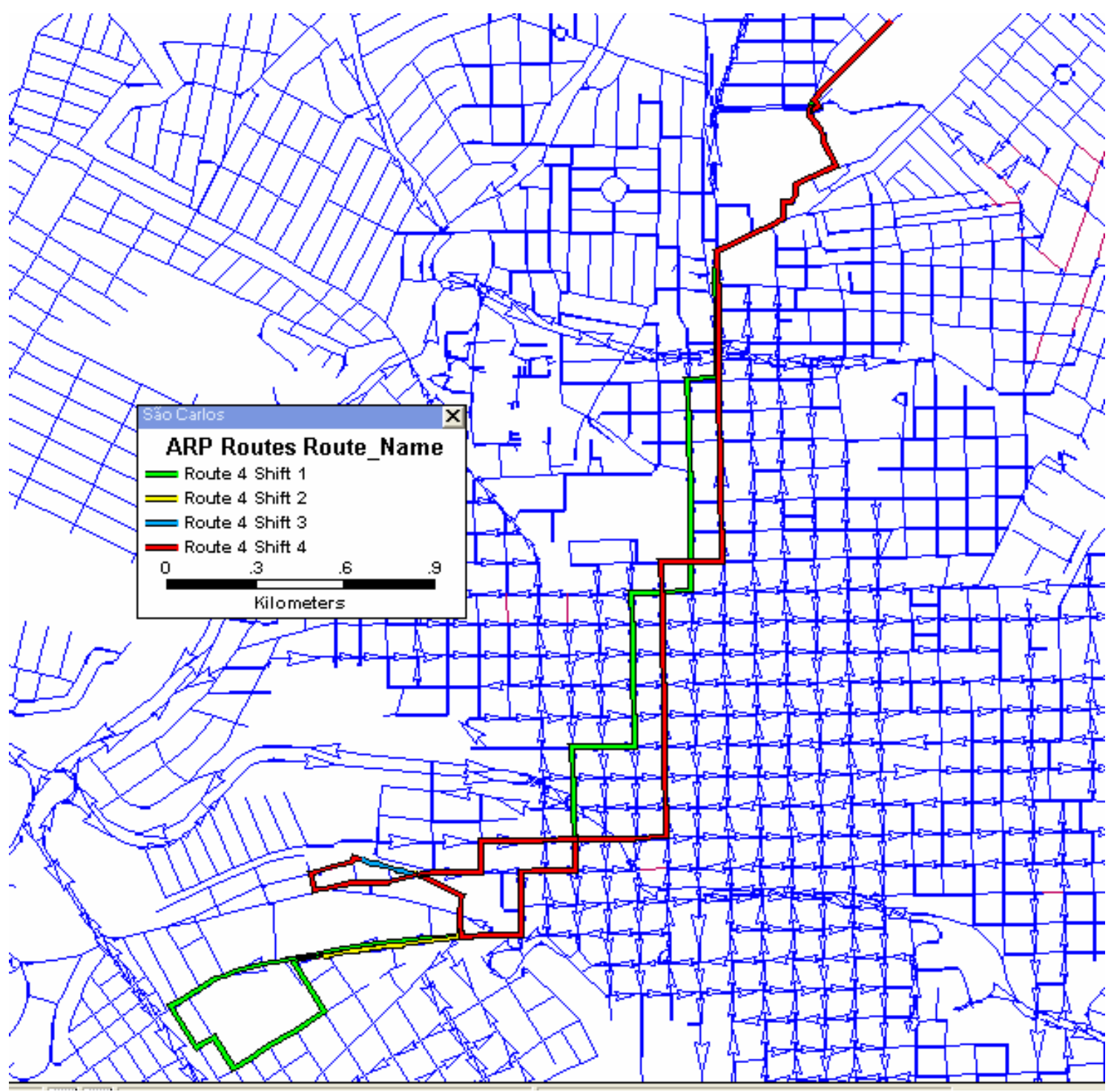

Figura 7.8 - Detalhe do roteiro da região 4 


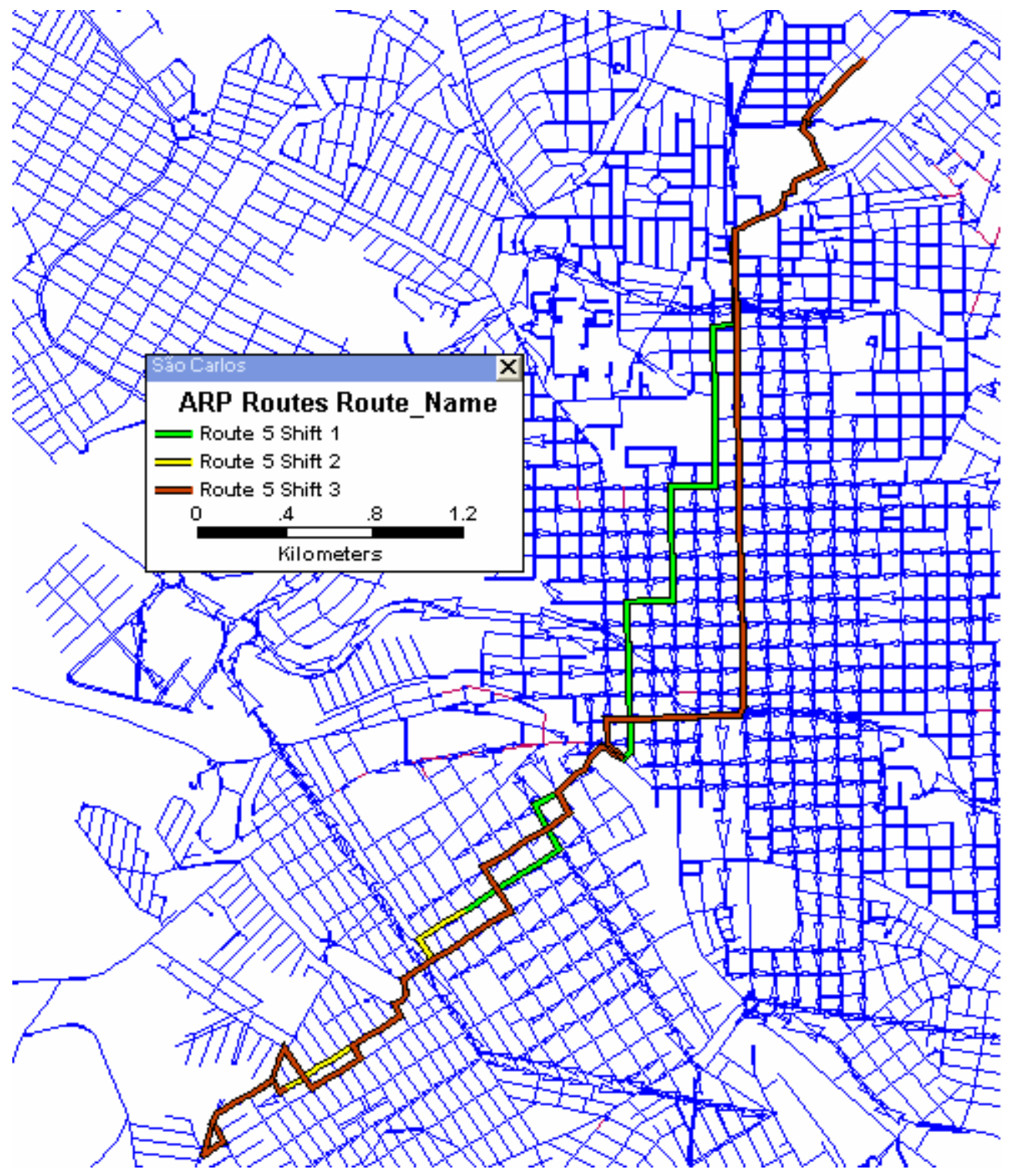

Figura 7.9 - Detalhe do roteiro da região 5 


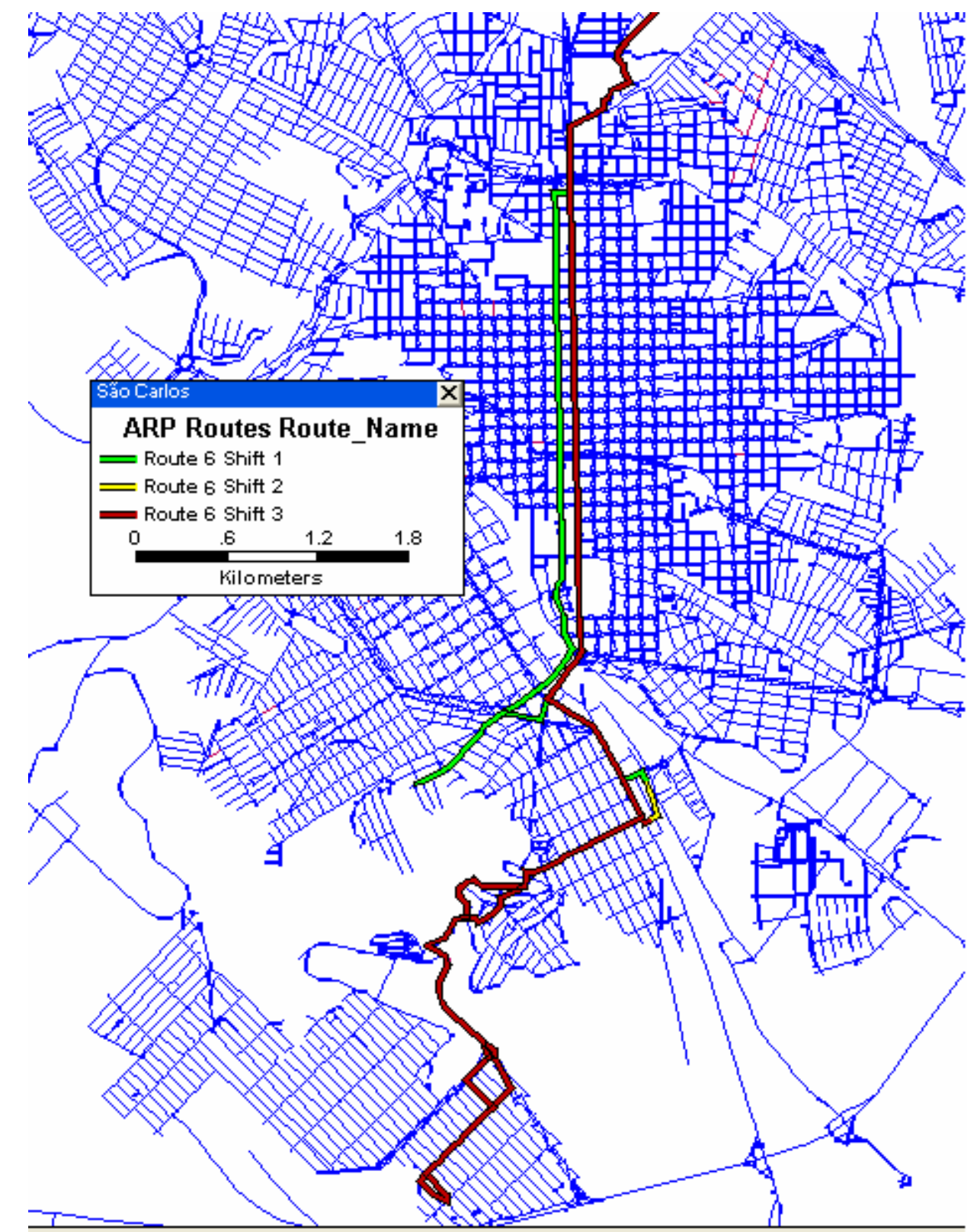

Figura 7.10 - Detalhe do roteiro da região 6 


\subsection{Previsão de Demanda por Serviços de Remendos}

O conjunto de dados obtidos sobre os remendos executados de janeiro até setembro de 2004 e a pluviosidade nesse mesmo período foram plotados no gráfico exposto na Figura 7.11.

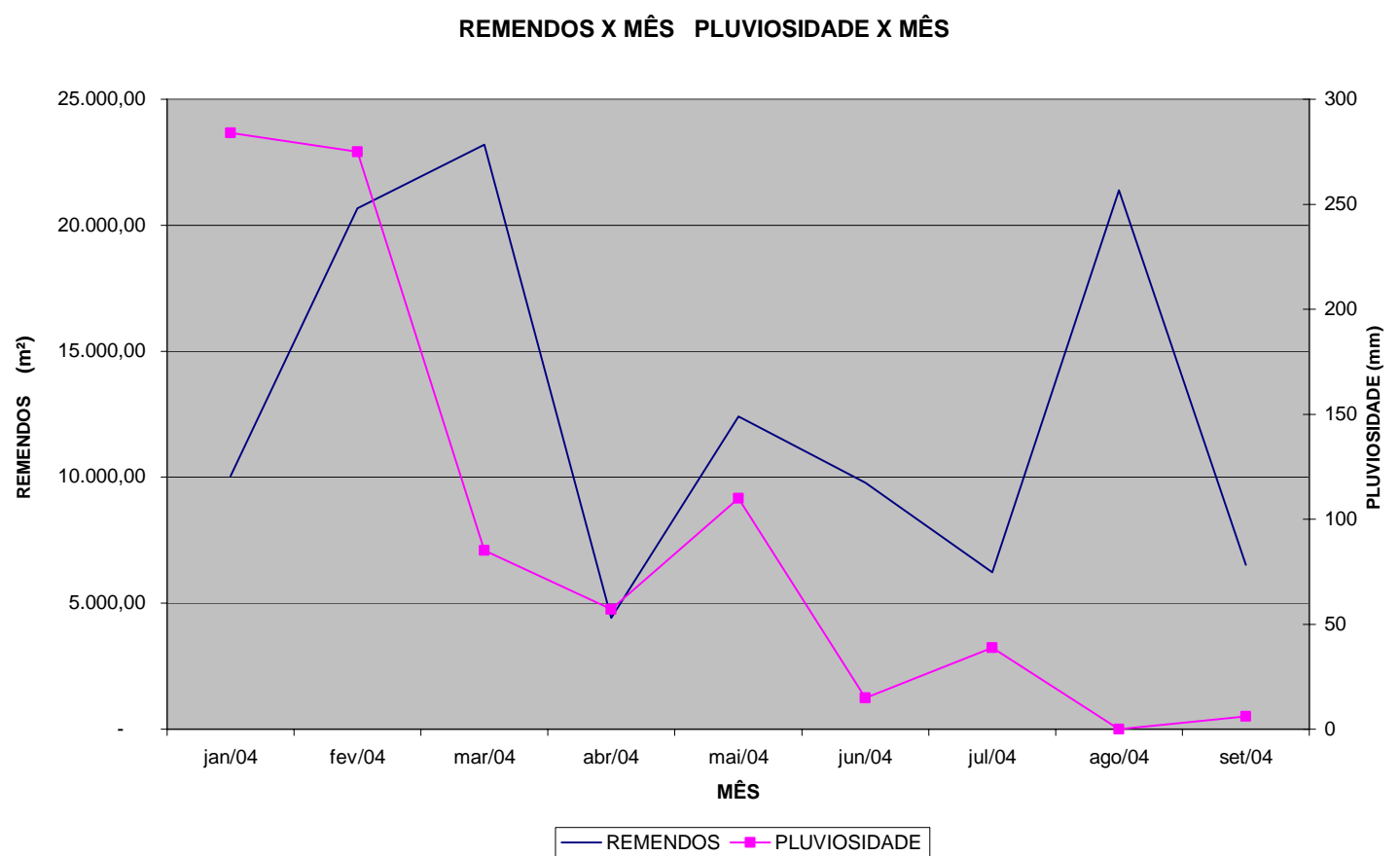

Figura 7.11 - Quantidades de remendos executados, e pluviosidade de Janeiro a Setembro de 2004

Como um dos fatores para o aparecimento das panelas é a pluviosidade, era esperado que com o aumento das chuvas houvesse também um aumento na quantidade de remendos executados.

Existe tal expectativa, pois a manutenção correta das vias tenta evitar a infiltração de água nas camadas do pavimento, evitando a deterioração precoce deste. Portanto, esperavasse que em períodos chuvosos mais panelas fossem formadas nos pavimentos, e então, para uma manutenção eficaz dos pavimentos, mais remendos fossem executados.

Analisando o gráfico azul (remendos executados) e o gráfico magenta (pluviosidade), observa-se que não existe tal relação. Alguns meses mais secos, como agosto, apresentam uma elevada quantidade de serviço, enquanto que o mês de janeiro, que possui elevada pluviosidade, apresenta pouca quantidade de serviço. 
Uma possível explicação para a pouca quantidade de serviço no mês de janeiro é que neste mês se deu o início do contrato da empresa responsável pelos remendos com a Prefeitura de São Carlos, podendo ter sido o mês de janeiro um período de adaptação da empresa ao serviço.

Outra explicação para a falta de relação entre as duas curvas é que nas épocas de chuvas os remendos necessários não são executados em todas as áreas, o que levou ao aumento da dimensão e número dessas panelas, aumentando assim a quantidade de remendos executados no mês seguinte.

Um objetivo secundário deste trabalho era a elaboração desta relação matemática, para poder prever a quantidade de remendos necessários de acordo com a estimativa da pluviosidade do período.

Então, foi plotada a distribuição dos remendos executados entre janeiro e setembro de 2004 versus a pluviosidade neste período, como mostra a Figura 7.12, a fim de correlacionar as duas.

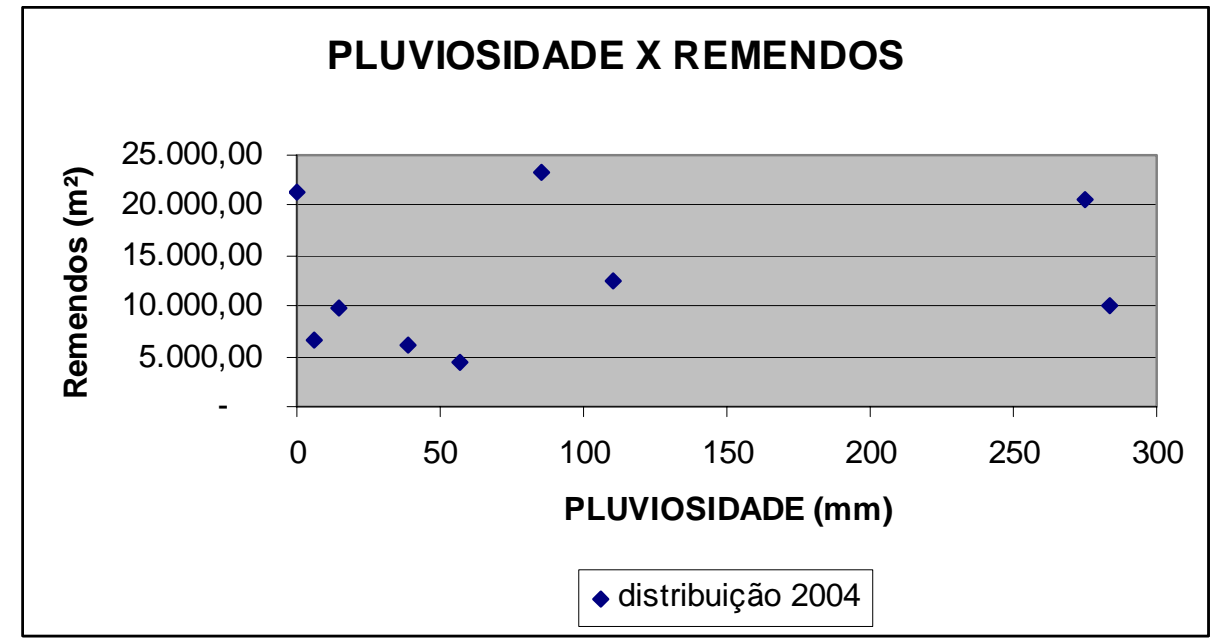

Figura 7.12 - Distribuição dos remendos executados versus a pluviosidade de Janeiro a Setembro de 2004

Porém, a distribuição observada não permite a correlação dos dados, pois além de muito dispersos, sua quantidade é muito pequena, tornando a elaboração de uma previsão de demanda muito difícil e de baixa confiabilidade.

Além disso, a quantidade de remendos executados apresentados pode não representar a quantidade de panelas que surgem num determinado período, pois tais panelas poderiam ter surgido em outras épocas, uma vez que a manutenção das vias da cidade não é eficaz. Observou-se, durante a coleta de dados, pedidos por serviços que ficaram meses esperando atendimento. 


\section{4 Melhorias}

Um serviço eficaz, em que as panelas são remendadas num intervalo curto de tempo, entre a comunicação de seu aparecimento e a execução do serviço, depende do conhecimento prévio da localização e do tamanho dessas panelas, além, é claro, de equipes, materiais e equipamentos adequados em quantidade e qualidade.

Assim, são sugeridas mudanças em relação ao antigo ciclo de pedidos, como mostra a Figura 7.13:

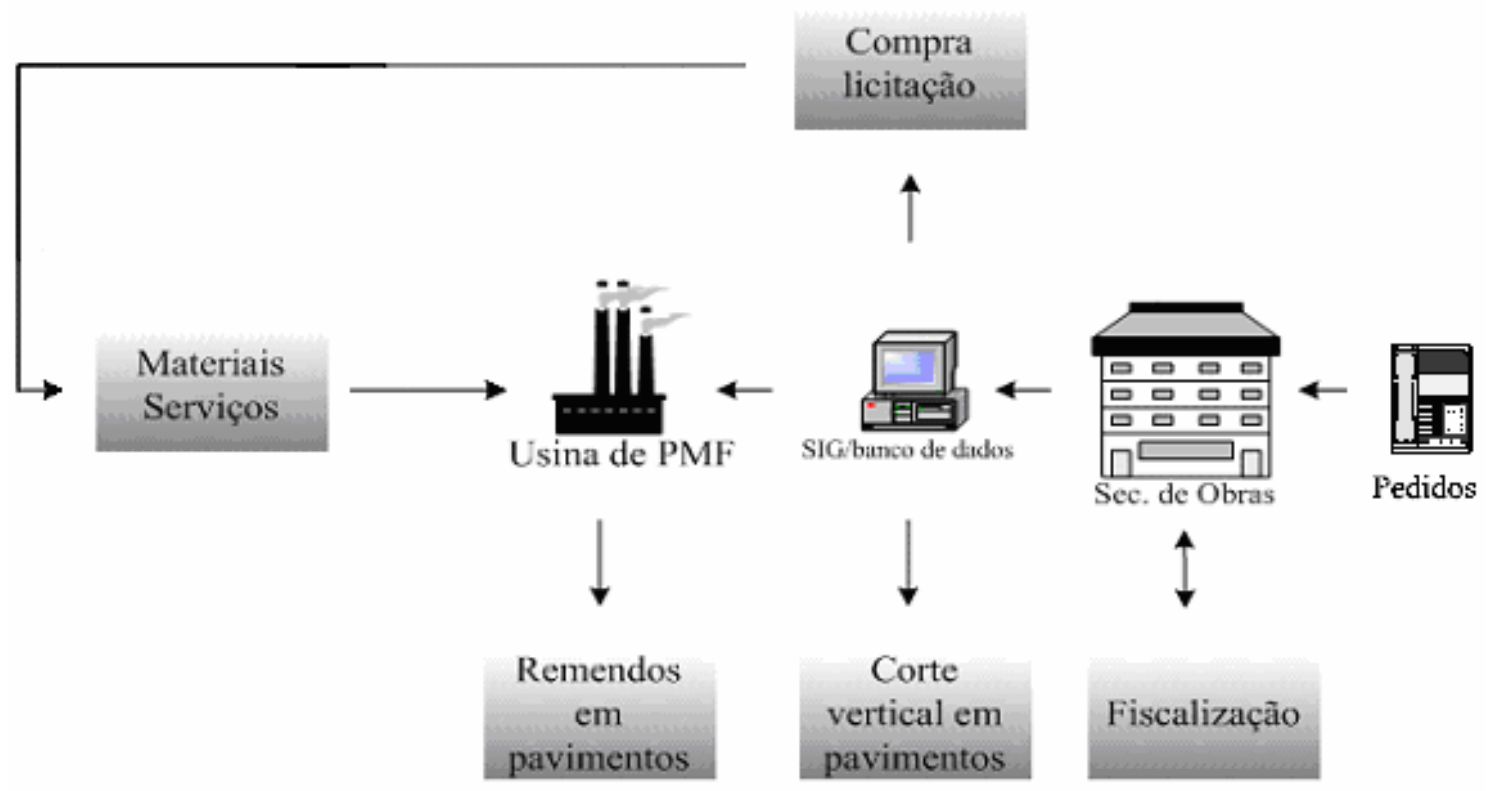

Figura 7.13 - Novo ciclo do pedido proposto

A comunicação sobre o aparecimento e a localização da panela poderia se dar através de um número de telefone próprio.

Um funcionário da prefeitura (fiscalização) ficaria encarregado de verificar no local as dimensões da panela e as condições das ruas próximas. A estrutura também serviria para fiscalizar os serviços executados anteriormente.

As informações sobre as panelas seriam, então, passadas ao banco de dados e ao SIG. O banco de dados armazenaria os dados sobre o serviço e sobre o aparecimento de panelas. O SIG seria usado para a roteirização e para avaliação das condições dos pavimentos da cidade. 
As informações geradas pelo SIG seriam o roteiro para as equipes de corte vertical de pavimentos, os roteiros para as turmas de remendos e quantidades para a produção de PMF ou CBUQ.

O histórico gerado com a localização e quantidade possibilitariam, também, estimar a demanda por serviço necessária para os próximos meses, ajudando a estimar as quantidades a serem adquiridas de serviços e materiais.

O novo ciclo tem como principal objetivo o atendimento da ocorrência, ou seja, remendar a panela no menor tempo possível, para se evitar o desconforto e aumento dos custos aos usuários e para se evitar a deterioração do pavimento pela infiltração de água em suas camadas.

O SIG, aliado ao uso de outras ferramentas logísticas, como o dimensionamento de frotas, por exemplo, também é necessário para que ocorra o sincronismo entre as equipes de corte vertical e de remendo, minimizando, assim, o tempo entre o corte do pavimento e seu remendo, evitando a exposição das camadas do pavimento à água e evitando transtornos aos usuários das vias. 


\section{CONCLUSÃO E PROPOSTA PARA TRABALHOS FUTUROS}

\subsection{Conclusões gerais}

O serviço de remendos em pavimentos possui um rendimento muito baixo, o que pode ser observado através da baixa velocidade de operação, de apenas $0,09 \mathrm{~km} / \mathrm{h}$.

A escolha dos itinerários como é feita hoje, através da experiência dos profissionais envolvidos, e pelos pedidos e até reclamações, muitas vezes excessivas em certas áreas da cidade, não favorece a melhoria do rendimento do serviço.

A quantidade de serviço contratada, geralmente estimada pelo valor da verba disponível no período, se mostrou insuficiente para os anos de 2004 e 2005, uma vez que a quantidade do contrato terminou antes do prazo estipulado.

Verifica-se a necessidade de uma avaliação técnica melhor das vias da cidade. Isso evitaria o uso de soluções incorretas ou incoerentes, como a execução de remendos de dimensões muito grandes ou de diversos remendos muito próximos uns aos outros.

O enfoque do serviço de remendos com o uso da Logística de Serviços, através de seus conceitos e ferramentas, em especial a roteirização de veículos, permite uma melhora na eficicácia deste serviço e assim um aumento de sua eficiência.

Para chegar a esses aumentos, a utilização de pacotes computacionais, como no caso deste estudo, o uso do SIG-T (TransCAD), se mostrou prática e necessária. 
Além do problema das vias das cidades, um SIG poderia auxiliar a gerência de outras infra-estruturas urbanas, como as redes de esgoto e água, as redes elétricas, além de auxiliar outros serviços urbanos como as rotas de ônibus, a coleta de lixo e muitos outros.

Porém, o uso de um SIG é acompanhado de certas dificuldades, algumas enfrentadas durante a elaboração desta dissertação, como os tempos gastos para o aprendizado do software, a elaboração da base de dados e o processamento de rotas.

Tais dificuldades também foram expostas por Santos (1999), que cita outras como o custo para a aquisição do software, os custos de treinamento de funcionários e compra dos equipamentos necessários.

Porém, esses custos poderiam ser pagos somente com as economias geradas pelo uso correto do software. Neste trabalho, a roteirização apresentou grandes melhorias no tempo gasto em serviço, na quilometragem percorrida e na quantidade de equipes. Tais melhorias geram economias muito grandes, pois além de diminuir o custo monetário, diminui também o custo social gerado por engarrafamentos e poluição, que são de difícil quantificação, e também auxilia na melhor preservação dos pavimentos, que possuem um valor elevado, evitando sucateamento da infra-estrutura existente.

Outra verificação importante é a necessidade do conhecimento prévio da quantidade de panelas e dos pontos críticos nas vias de São Carlos, para que seja possível a correta aplicação dos conceitos e ferramentas da Logística de Serviços.

Tal conhecimento permite uma melhor alocação de recursos nos tempos e locais corretos, através da roteirização de veículos, além de possibilitar uma estimativa mais precisa de tais recursos ao longo do tempo, por meio de métodos de previsão de demanda. 


\subsection{Conclusões sobre os resultados obtidos}

O uso do SIG se mostrou muito eficiente, pois possibilitou o uso da ferramenta de roteirização e a conseqüente diminuição de custos (tempos de trabalho e distâncias percorridas), além de permitir a emissão de itinerários para cada equipe, como os apresentados no ANEXO $A$, e também a visualização gráfica destas rotas, permitindo sua compreensão espacial entre os diversos locais estabelecidos pelo itinerário.

A roteirização gerou como resultados a diminuição em 29,70\% da quilometragem total percorrida, em $28,89 \%$ do tempo trabalhado total e de $30,77 \%$ da quantidade total de equipes necessárias para executar o mesmo serviço.

Tal diminuição favorece a economia de recursos por parte das empresas e, conseqüentemente, a diminuição dos custos do serviço. Outra vantagem da roteirização é o melhor controle que a empresa terá sobre o serviço, através de uma estimativa melhor dos materiais, equipamentos e funcionários necessários.

A estimativa correta de funcionários permite que cada equipe trabalhe a mesma quantidade de horas, evitando o pagamento de horas extra para alguns funcionários enquanto outros ficam ociosos.

Para o município as vantagens são: a correta alocação do serviço em termos de local e tempo em que são necessários, a melhor preservação do patrimônio público, no caso as vias e a diminuição dos custos aos cidadãos (maior segurança no trânsito, menor consumo de combustíveis, diminuição nas quebras de veículos ocasionados pela má conservação das ruas).

Com relação à previsão de demanda, não foi possível estabelecer uma relação entre a pluviosidade e a quantidade de panelas existentes nas vias, devido à falta de dados.

Porém, observou-se que os serviços em São Carlos não são distribuídos seguindo as quantidades de chuvas em um ano e sim muitas vezes seguindo um orçamento pré-estabelecido, sem qualquer relação com os eventos que causam as panelas. 
Mesmo no decorrer do ano observa-se que a aplicação dos recursos não é adequada, acontecendo muitas vezes logo as chuvas, o que acelera a deterioração do pavimento.

As melhorias propostas neste trabalho possibilitariam o enriquecimento desses dados históricos e assim uma melhor previsão de demanda a cada época do ano, de acordo com critérios e parâmetros estabelecidos.

O novo ciclo proposto permite, também, um melhor controle do serviço, pois as quantidades já estariam determinadas anteriormente à execução do serviço, o que ajudaria a fiscalização, prevendo-se, também, o corte vertical do pavimento, o que aumentaria a qualidade e durabilidade do pavimento.

\subsection{Proposta para trabalhos futuros}

\subsubsection{Modelo de Previsão de Demanda}

A tentativa de estabelecer uma relação matemática de previsão de demanda mostrou a falta de dados históricos, fundamentais para tal tarefa. A previsão do aparecimento de panelas a cada época do ano ajudaria na estimativa de serviços e materiais a serem comprados e contratados pela prefeitura, como mostrado anteriormente.

Por isso, seria interessante o estabelecimento de tal relação de demanda, usando além da pluviosidade, outros fatores para o aparecimento de panelas como, por exemplo, a idade dos pavimentos da cidade e o fluxo de veículos que passam por esses pavimentos.

\subsubsection{Dimensionamento de frotas}

Com o uso da roteirização, encontraram-se novos rendimentos das equipes de remendos, porém não é levado em conta se as equipes de fato suportam tais aumentos de rendimento.

Um estudo sobre o rendimento máximo de cada equipe seria interessante, o que determinaria outro limite para a roteirização, além do tempo de serviço por dia e a carga do caminhão.

O uso dessa informação, aliado à escolha de diferentes veículos e equipamentos, mais a determinação da quantidade de serviços a serem executados e os conceitos do dimensionamento de frotas, levaria à 
determinação da quantidade de funcionários e equipamentos necessários ao serviço de remendos em um período.

\subsubsection{Pesquisa operacional}

Como apresentado no Capítulo 3, uma cidade precisa traçar um planejamento estratégico com a elaboração de uma política de manutenção dos pavimentos de uma cidade, com o estabelecimento da qualidade aceitável desses pavimentos e, conseqüentemente, a determinação das quantidades de serviços e materiais que serão contratados durante um horizonte de tempo.

Para isso, o uso da Pesquisa Operacional, em especial a Programação Dinâmica, seria uma ferramenta útil no traçado dessa estratégia e na análise de conseqüências devido às atitudes tomadas. 


\section{REFERÊNCIAS BIBLIOGRÁFICAS}

AL-SHAWI, M.; CABRERA, J.G.; WATSON, A.S. (1987) Transport \& Planning. In: SUMMER ANUAL MEETING, 15 ${ }^{\text {th }}$ 1987. Anais, Highway Construction and Maintenance. p.43-58.

ALVARENGA, A.C.; NOVAES, A.G. (2000) Logística Aplicada: Suprimento e Distribuição Física. $3^{a}$ edição, São Paulo: Edgard Brücher.

Associação Brasileira das Empresas Distribuidoras de Asfaltos - ABEDA (2001). Manual Básico de Emulsões Asfálticas: Soluções para Pavimentar sua Cidade. Rio de Janeiro: York.

BALLOU, R.H. (1993). Logística Empresarial: Transporte, Administração de Materiais e Distribuição Física. Tradução de Hugo T.Y. $1^{a}$ edição, São Paulo: Atlas.

BALLOU, R.H. (2001). Gerenciamento da Cadeia de Suprimentos Planejamento, Organização e Logística Empresarial. Tradução de Elias Pereira. $4^{\mathrm{a}}$ edição, Porto Alegre: Bookman.

BERTOLLO, S.A.M. (1997). Considerações sobre a Gerência de Pavimentos Urbanos em Nível de Rede. São Carlos. 194p. Dissertação (Mestrado) - Escola de Engenharia de São Carlos, Universidade de São Paulo, 30/06/1997. 
BOWERSOX, D.J.; CLOSS, D.J. (2001). Logística Empresarial - O Processo de Integração da Cadeia de Suprimento. Tradução da equipe do Centro de Estudos em Logística, Adalberto Ferreira das Neves. $1^{a}$ edição, São Paulo: Atlas.

CALIPER (1999). Routing and Logistics with TransaCAD (Transportation GIS software), Caliper Corporation, version 3.5.

DE SENÇO, W. (2001). Manual e Técnicas de Pavimentação, volume $2-1^{\mathrm{a}}$ edição. São Paulo: PINI.

DELUQUI, K.K. (1998). Roteirização para veículos de coleta de resíduos sólidos domiciliares utilizando um Sistema de Informações Geográficas-SIG. São Carlos. 222p. Dissertação (Mestrado) - Escola de Engenharia de São Carlos, Universidade de São Paulo, 18/09/1998.

DORNIER, P.; ERNEST, R.; FENDER, M;, KOUVELIS, P. (2000) Logística e Operações Globais: Textos e Casos. Tradução Arthur Itakagi Utiyama, $1^{\text {a }}$ edição, São Paulo: Atlas.

Embrapa Pecuária Sudeste (2005). Pluviosidade para a cidade de São Carlos. Disponível em: http://www.cppse.embrapa.br> , acesso em 15 de junho.

EISELT, H.A.; ENDREAU, M.; LAPORTE G. (1995). Arc Routing Problems, Part I: The Chinese Postman Problem. Operation Research 43, $n^{\circ} 2$, p.231242. 
EILON, S.; ATTSON-GANDY, C; CHRISTOFIDES, N. (1971) Distribution Management: Mathematical Modeling and andPractcal Analysis. $1^{\mathrm{a}}$ edição, New York: Hafner.

FIGUEIREDO, K. (2000). Rentabilidade de Clientes e Nível de Serviço In: FLEURY, J.F. et al. Logística Empresarial - A Perspectiva Brasileira. São Paulo: Atlas., cap. 3, p. $65-76$.

FERNANDES JÚNIOR, J.L.; ODA, S.; ZERBINI, L.F. (2001). Defeitos e Atividades de Manutenção e Reabilitação em Pavimentos Asfálticos. Apostila. Escola de Engenharia de São Carlos, USP, São Carlos.

HAAS, R; HUDSON, W.R. (1996). Defining and serving clients for pavements. Transportation Research Record, n.1435, p1-9.

HESKETT, J.L.; EVANS, C. D. (1994). Contemporary Issues in Logistics In: ROBESON, J.F. et al. The Logistics Handbook. New York: The Free Press. 10a Seção, cap. 41 , p. 859 - 868.

HESKETT , J.L.; SASSER Jr., W.E.; HART, C.W.L. (1994). Serviços Revolucionários: Mudando as Regras do Jogo Competitivo Na Prestação de Serviços. Tradução de Carmem Dolores Straube e Irineu Gustavo Gianesi. São Paulo: Pioneira.

Instituto Brasileiro de Geografia e Estatística - IBGE (2005). Censo Demográfico 2000. Disponível em: <http://www.ibge.gov.br>, acesso em 13 de fevereiro. 
LIMA, J.P., LOPES, S.B., ZANCHETTA, F., ANELLI, R., FERNANDES Jr., J.L. (2004). Uso de SIG para a Gerência de Infra-estrutura de Transportes: Estudo de Caso em São Carlos-SP. In: PLANEJAMENTO INTREGADO: EM BUSCA DE DESENVOLVIMENTO SUSTENTÁVEL PARA CIDADES DE PEQUENO E MÉDIO PORTES. 1ª edição, Universidade do Minho, Braga.

MANUAL TÉCNICO DERSA - ANEXO II (1988). Instrução para execução de remendos em pavimento flexível - OP-02-04 (OP/DEECA). São Paulo.

MASCARÓ, J. L. (1989). Desenho Urbano e Custos de Urbanização. $2^{a}$ edição, Porto Alegre: D. C. Luzzatto.

MASI, A.; ALMEIDA, J.I.S. (1994). Manutenção, Conservação e Restauração de Pavimentos Urbanos. In: REUNIÃO DE PAVIMENTAÇÃO URBANA, 5a . 1994, Natal. Anais...NAtal, Associação Brasileira de Pavimentação, Natal. p.309-330.

MELO, R. A. (1998). Avaliadores, notas e qualidade de pavimentos. São Carlos. 107p. Dissertação (Mestrado) - Escola de Engenharia de São Carlos, Universidade de São Paulo, 04/05/1998.

MIRANDA, C. (2004). Depois das chuvas, cidade cheia de buracos. Estado de São Paulo, São Paulo, 28 de fevereiro. Cidades, p C1.

MOTTA, L.M.G. (1995). Considerações a respeito de pavimentos e tráfego em vias urbanas. In: REUNIÃO DE PAVIMENTAÇÃO URBANA, 6 ${ }^{\mathrm{a}}$. 1995, Santos. Anais...Santos, Associação Brasileira de Pavimentação, Santos. p.26-52.

MUG, M. (2004). Destruídas, estradas aguardam verbas federais. Estado de São Paulo, São Paulo, 05 de março. Cidades, p C1. 
NARUO, M.K. (2003). O estudo de consórcios entre municípios de pequeno porte para disposição final de resíduos sólidos urbanos utilizando sistema de informações geográficas. 286p. Dissertação (Mestrado) - Escola de Engenharia de São Carlos, Universidade de São Paulo, 07/07/2003.

NOVAES, A.G. (1989) Sistemas Logísticos: Transporte, Armazenagem e Distribuição Física de Produtos. $1^{a}$ edição, São Paulo: Edgard Blücher.

OLIVEIRA, C.A.K. (1994). Manutenção, Conservação e Restauração de Pavimentos Urbanos. In: REUNIÃO DE PAVIMENTAÇÃO URBANA, $5^{a}$. 1994, Natal. Anais...Natal, Associação Brasileira de Pavimentação, Natal. p.309-330.

PANTIGOSO, J.F.G., FERNANDES Jr., J.L. (1997). Compatibilização da gerência de pavimentos urbanos com as concessionárias de serviços públicos com o uso de SIG in XI CONGRESSO DE PESQUISA E ENSINO EM TRANSPORTES - ANPET. $1^{a}$ edição, Universidade Federal do Rio de Janeiro, Rio de Janeiro, p. 67-70.

PELIZARO, C. (2000). Avaliação de desempenho do algorítimo de um programa comercial para roteirização de veículos. 153p. Dissertação (Mestrado) - Escola de Engenharia de São Carlos, Universidade de São Paulo, 15/05/2000.

SALMI, C.A.; PEREIRA, A.M.; CONFORTINI, A.C.; GONÇALVES, A.G.; DA SILVA, L.G. (1996). A Conservação de Pavimentos em Vias Urbanas de São José dos Campos. In: REUNIÃO DE PAVIMENTAÇÃO URBANA, 7a. 1996, São José dos Campos. Anais...São José dos Campos, Associação Brasileira de Pavimentação, São José dos Campos. p.263-273. 
SANTOS, C.M. (1999). A viabilização de softwares comerciais na roteirização de veículos de serviços de entregas, visando a geração de respostas rápidas e eficientes. 203p. Dissertação (Mestrado) - Escola de Engenharia de São Carlos, Universidade de São Paulo, 29/04/1999.

SARKIS, L.F.P.G. (2000). Resíduos de Serviços de Saúde em Caracterização de Sistemas de Coleta e Aplicação de um Sistema de Informação Geográfica na Roteirização de Veículos de Coleta e Transporte. 216p. Dissertação (Mestrado) - Escola de Engenharia de São Carlos, Universidade de São Paulo, 28/04/2000.

SILVA, A.N.R. (1998). Sistemas de informações geográficas para planejamento de transportes. 112p. Tese (Livre Docência) - Escola de Engenharia de São Carlos, Universidade de São Paulo.

SILVA, V.B. (2005). Distribuição modal rodo-ferroviária em uma rede de exportação de açúcar a granel para o porto de Santos. 182p. Dissertação (Mestrado) - Escola de Engenharia de São Carlos, Universidade de São Paulo, 26/04/2005.

SOUSA, K.L.O. (1993). Uma proposta de política pública na gestão do sistema viário urbano. In: REUNIÃO DE PAVIMENTAÇÃO URBANA, $4^{\mathrm{a}}$. 1993, Maceió. Anais...Maceió, Associação Brasileira de Pavimentação, Maceió. P.28-52.

THOMPSON, R. G. e TANIGUCHI, E. (2001). City Logistics and Freight Transport. In: BREWER A.M. et al. Handbook of Logistics and Suply-Chain Management. Amsterdam: Pergamon, Cap. 25, p. 393-406. 
VERMA, R. (2001). Services Marketting. In: BREWER A.M. et al. Handbook of Logistics and Suply-Chain Management. Amsterdam: Pergamon, Cap. 17 , p. 271-291.

VILIBOR, D.F., FORTES, F.Q., FERNANDES, S.B. (1993). Recuperação de pavimentos flexíveis em vias urbanos. In: REUNIÃO DE PAVIMENTAÇÃO URBANA, 4 a . 1993, Maceió. Anais...Maceió, Associação Brasileira de Pavimentação, Maceió. P.438-476.

WAGNER, H.M. (1986). Pesquisa Operacional. Tradução de Paulo Antônio Mariotto. $2^{a}$ edição, Rio de Janeiro: Prentice-Hall do Brasil.

ZANCHETTA (2005). Aquisição de Dados sobre as Condições dos Pavimentos Visando a Implementação de Sistemas de Gerência de Pavimentos Urbanos. 111p. Dissertação (Mestrado) - Escola de Engenharia de São Carlos, Universidade de São Paulo, 06/01/2005.

WANKE, P. (2000). Importância do Processo de Previsão de Vendas para o Negócio In: FLEURY, J.F. et al. Logística Empresarial - A Perspectiva Brasileira. São Paulo: Atlas., cap. 7, p. 209 - 226. 
ANEXO A ITINERÁRIOS (TransCAD) 
Itinerary Report

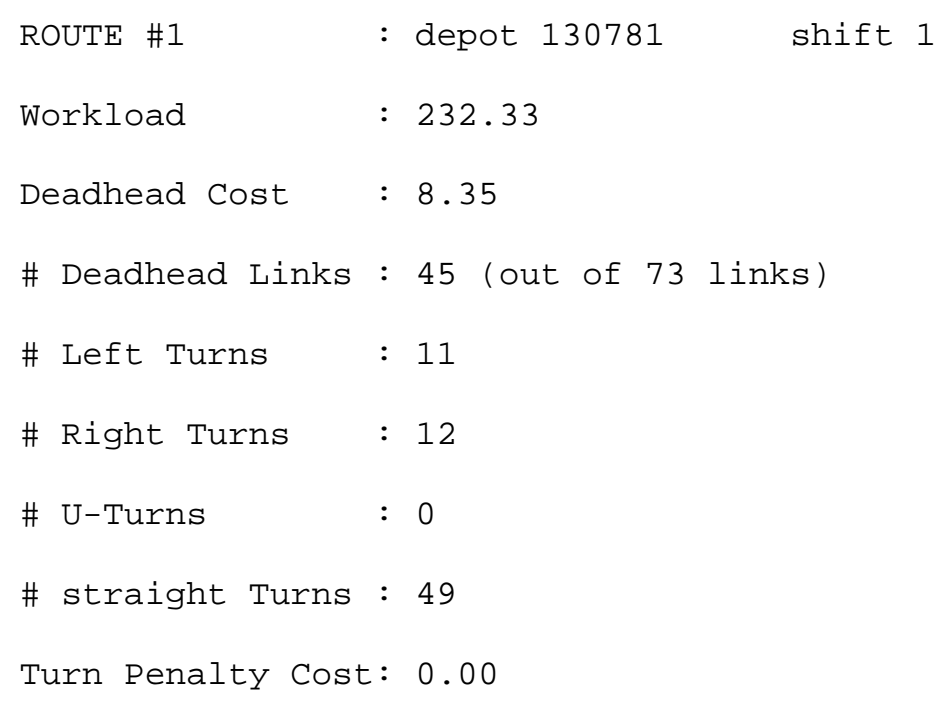

\begin{tabular}{|c|c|c|}
\hline 1 & Start West on & RUA SANTOS DUMONT \\
\hline 2 & Right on & RUA ROTARY CLUBE \\
\hline 3 & Continue on & RUA ROTARY CLUBE \\
\hline 4 & Left on & RUA ROTARY CLUBE \\
\hline 5 & Continue on & RUA ROTARY CLUBE \\
\hline 6 & Right on & RUA JOAO LEOPOLDINO \\
\hline 7 & Left on & RUA LUIZ VAZ DE CAMOES \\
\hline 8 & Right on & RUA FRANCISCO MARICONDE \\
\hline 9 & Right on & AV PROF LUIZ AUGUSTO DE \\
\hline 10 & Continue on & AV PROF LUIZ AUGUSTO DE \\
\hline 11 & Continue on & AV PROF LUIZ AUGUSTO DE \\
\hline 12 & Continue on & ROD SP-318 \\
\hline 13 & Continue on & ROD SP-318 \\
\hline 14 & Continue on & ROD SP-318 \\
\hline 15 & Continue on & ROD SP-318 \\
\hline & Continue on & ROD SP-318 \\
\hline
\end{tabular}




\begin{tabular}{|c|c|c|c|}
\hline 17 & Continue on & ROD SP-318 & No \\
\hline 18 & Continue on & ROD SP-318 & No \\
\hline 19 & Continue on & ROD SP-318 & No \\
\hline 20 & Continue on & ROD SP-318 & No \\
\hline 21 & Continue on & EST MUNICIPAL SCA-๑70 & No \\
\hline 22 & Continue on & EST MUNICIPAL SCA-๑7๑ & No \\
\hline 23 & Continue on & EST MUNICIPAL SCA-๑70 & No \\
\hline 24 & Continue on & EST MUNICIPAL SCA-๑7๑ & No \\
\hline 25 & Left on & AV FRANCISCO FALVO & No \\
\hline 26 & Continue on & AV FRANCISCO FALVO & No \\
\hline 27 & Right on & RUA NICOLA DIBBO & No \\
\hline 28 & Left on & RUA RHEDA WIDENBRUCK & No \\
\hline 29 & Right on & RUA GUTTINGEN & No \\
\hline 30 & Continue on & RUA GUTTINGEN & No \\
\hline 31 & Right on & RUA GUILHERME ORLANDO SA & No \\
\hline 32 & Continue on & RUA GUILHERME ORLANDO SA & Yes \\
\hline 33 & Continue on & RUA GUILHERME ORLANDO SA & Yes \\
\hline 34 & Continue on & RUA GUILHERME ORLANDO SA & Yes \\
\hline 35 & Left on & RUA NICOLA DIBBO & No \\
\hline 36 & Continue on & RUA NICOLA DIBBO & No \\
\hline 37 & Left on & RUA MAURO DIAS CORREA & No \\
\hline 38 & Right on & RUA JOSE ELIZIO DE OLIVE & No \\
\hline 39 & Left on & RUA MAURO DIAS CORREA & No \\
\hline 40 & Right on & BORLANGE; RUA & No \\
\hline 41 & Continue on & BORLANGE； RUA & Yes \\
\hline 42 & Continue on & BORLANGE； RUA & Yes \\
\hline 43 & Continue on & BORLANGE; RUA & Yes \\
\hline 44 & Continue on & BORLANGE； RUA & Yes \\
\hline 45 & Continue on & BORLANGE; RUA & Yes \\
\hline 46 & Continue on & BORLANGE; RUA & Yes \\
\hline
\end{tabular}




\begin{tabular}{|c|c|c|}
\hline 47 & Left on & RUA JOAQUIM DE MEIRA BOT \\
\hline 48 & Right on & GUILHERME FRIGORI; RUA \\
\hline 49 & Continue on & GUILHERME FRIGORI; RUA \\
\hline 50 & Continue on & GUILHERME FRIGORI; RUA \\
\hline 51 & Continue on & GUILHERME FRIGORI; RUA \\
\hline 52 & Continue on & GUILHERME FRIGORI; RUA \\
\hline 53 & Continue on & GUILHERME FRIGORI; RUA \\
\hline 54 & Continue on & GUILHERME FRIGORI; RUA \\
\hline 55 & Continue on & GUILHERME FRIGORI; RUA \\
\hline 56 & Continue on & GUILHERME FRIGORI; RUA \\
\hline 57 & Continue on & GUILHERME FRIGORI; RUA \\
\hline 58 & Left on & RUA VALERIO RIBEIRO \\
\hline 59 & Left on & RUA ERNESTO BENTIN \\
\hline $6 \odot$ & Left on & RUA JOAQUIM DE MEIRA BOT \\
\hline 61 & Continue on & RUA JOAQUIM DE MEIRA BOT \\
\hline 62 & Right on & CHOJNICE； RUA \\
\hline 63 & Continue on & CHOJNICE; RUA \\
\hline 64 & Continue on & CHOJNICE; RUA \\
\hline 65 & Continue on & CHOJNICE; RUA \\
\hline 66 & Continue on & CHOJNICE; RUA \\
\hline 67 & Continue on & CHOJNICE; RUA \\
\hline 68 & Continue on & CHOJNICE; RUA \\
\hline 69 & Continue on & CHOJNICE; RUA \\
\hline 70 & Continue on & CHOJNICE; RUA \\
\hline 71 & Right on & RUA MAURO DIAS CORREA \\
\hline 72 & Continue on & RUA MAURO DIAS CORREA \\
\hline 73 & Continue on & RUA MAURO DIAS CORREA \\
\hline
\end{tabular}




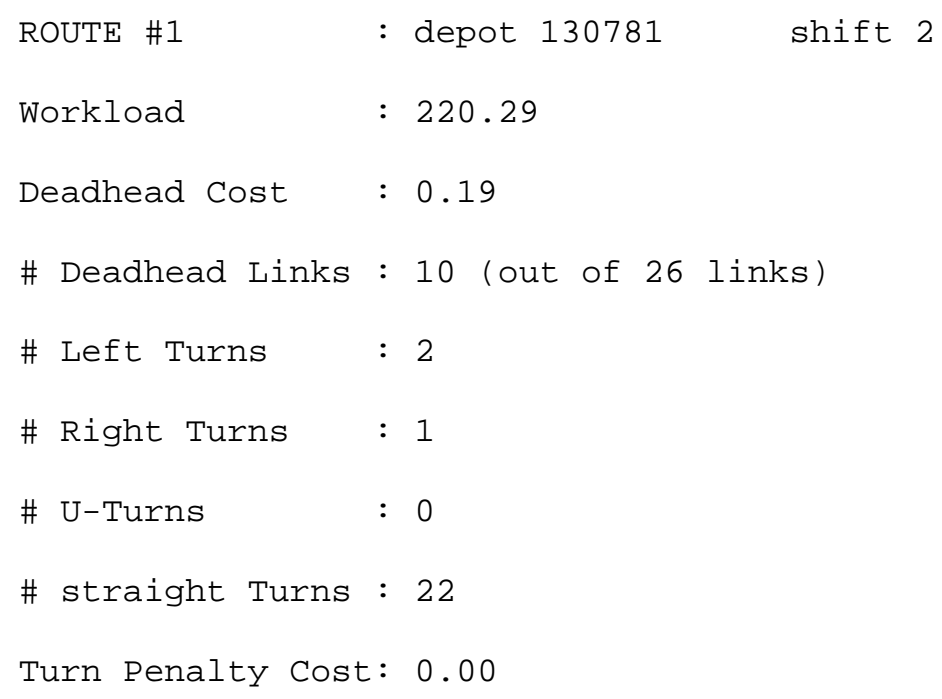




$\begin{array}{llll}19 & \text { Continue on } & \text { RUA PRES JOAO BELCHIOR M } & \text { Yes } \\ 20 & \text { Continue on } & \text { RUA PRES JOAO BELCHIOR M } & \text { Yes } \\ 21 & \text { Continue on } & \text { RUA PRES JOAO BELCHIOR M } & \text { Yes } \\ 22 \text { Continue on } & \text { RUA PRES JOAO BELCHIOR M } & \text { Yes } \\ 23 \text { Continue on } & \text { RUA PRES JOAO BELCHIOR M } & \text { No } \\ 24 \text { Left on } & \text { RUA JOSE RIGA } & \text { No } \\ 25 \text { Right on } & \text { JOSE FERRAZ; RUA } & \text { Yes } \\ 26 \text { Continue on } & \text { JOSE FERRAZ; RUA } & \text { Yes }\end{array}$

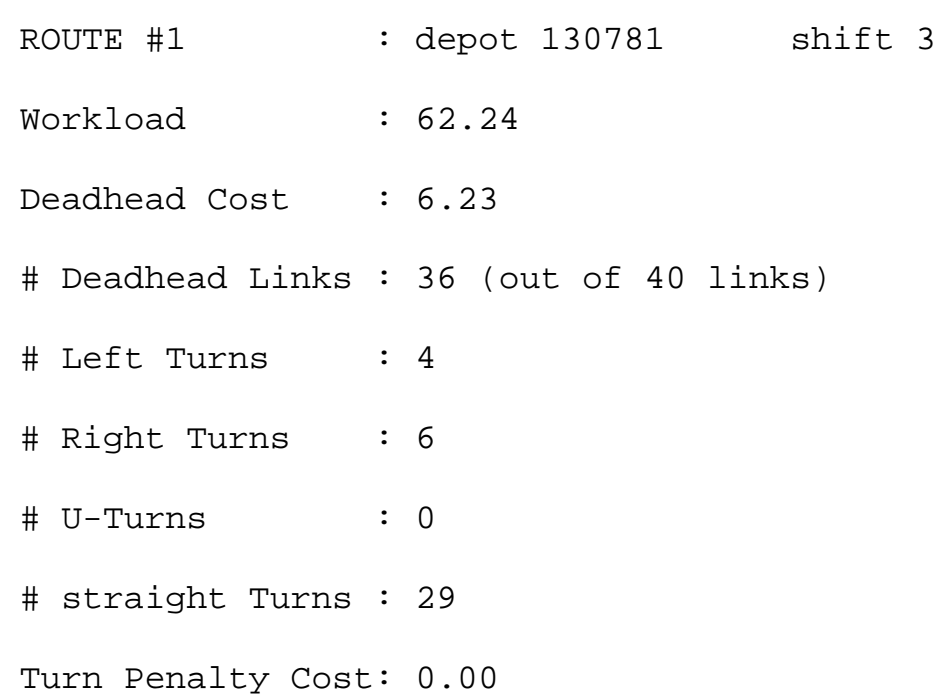




\begin{tabular}{|c|c|c|}
\hline 11 & Continue on & RUA GUILHERME ORLANDO SA \\
\hline 12 & Continue on & RUA GUILHERME ORLANDO SA \\
\hline 13 & Continue on & RUA GUILHERME ORLANDO SA \\
\hline 14 & Right on & RUA NICOLA DIBBO \\
\hline 15 & Continue on & RUA NICOLA DIBBO \\
\hline 16 & Left on & AV FRANCISCO FALVO \\
\hline 17 & Continue on & AV FRANCISCO FALVO \\
\hline 18 & Right on & EST MUNICIPAL SCA-๑7๑ \\
\hline 19 & Continue on & EST MUNICIPAL SCA-๑7๑ \\
\hline 20 & Continue on & EST MUNICIPAL SCA-๑7๑ \\
\hline 21 & Continue on & EST MUNICIPAL SCA-๑7๑ \\
\hline 22 & Continue on & ROD SP-318 \\
\hline 23 & Continue on & ROD SP-318 \\
\hline 24 & Continue on & ROD SP-318 \\
\hline 25 & Continue on & ROD SP-318 \\
\hline 26 & Continue on & ROD SP-318 \\
\hline 27 & Continue on & ROD SP-318 \\
\hline 28 & Continue on & ROD SP-318 \\
\hline 29 & Continue on & ROD SP-318 \\
\hline 30 & Continue on & ROD SP-318 \\
\hline 31 & Continue on & AV PROF LUIZ AUGUSTO DE \\
\hline 32 & Continue on & ROD WASHINGTON LUIZ \\
\hline 33 & Continue on & ROD WASHINGTON LUIZ \\
\hline 34 & Continue on & ROD WASHINGTON LUIZ \\
\hline 35 & Continue on & ROD WASHINGTON LUIZ \\
\hline 36 & Right on & RUA JOSE FERRAZ DE CAMAR \\
\hline 37 & Right on & RUA JOSE FERRAZ DE CAMAR \\
\hline 38 & Left on & TR SERGIO $\mathrm{F} P$ FLEURY \\
\hline 39 & Right on & RUA SANTOS DUMONT \\
\hline 40 & Continue on & RUA SANTOS DUMONT \\
\hline
\end{tabular}

